RONEY NAKANO VITORINO

\title{
PERCEPÇÃO DE PREÇOS E AFERIÇÃO DOS RISCOS DE EXPOSIÇÃO FINANCEIRA NO AMBIENTE DE CONTRATAÇÃO LIVRE
}

\author{
Dissertação apresentada à Escola \\ Politécnica da Universidade de São Paulo \\ para obtenção do título de mestre em \\ Engenharia
}


RONEY NAKANO VITORINO

\title{
PERCEPÇÃO DE PREÇOS E AFERIÇÃO DOS RISCOS DE EXPOSIÇÃO FINANCEIRA NO AMBIENTE DE CONTRATAÇÃO LIVRE
}

\author{
Dissertação apresentada à Escola \\ Politécnica da Universidade de São Paulo \\ para obtenção do título de mestre em \\ Engenharia \\ Área de Concentração: \\ Sistemas de Potência
}

Orientador:

Prof. Dr. Dorel Soares Ramos

São Paulo

2011 
Este exemplar foi revisado e alterado em relação à versão original, sob responsabilidade única do autor e com a anuência de seu orientador.

São Paulo, de novembro de 2011.

Assinatura do autor

Assinatura do orientador

FICHA CATALOGRÁFICA

Vitorino, Roney Nakano

Percepção de preços e aferição dos riscos de exposição fi nanceira no ambiente de contratação livre/ R.N. Vitorino. -ed.rev. -- São Paulo, 2011.

$122 \mathrm{p}$.

Dissertação (Mestrado) - Escola Politécnica da Universidade de São Paulo. Departamento de Engenharia de Energia e Automação Elétricas.

1. Energia elétrica 2. Planejamento energético 3. Consumo de

energia elétrica 4. Gestão de fornecimento 5. Energia elétrica (Economia) I. Universidade de São Paulo. Escola Politécnica. Departamento de Engenharia de Energia e Automação Elétricas II. t. 


\section{DEDICATÓRIA}

Aos meus pais, João e Kenko, às minhas irmãs, Caroline e Carine, pelo apoio e motivação. 


\section{AGRADECIMENTOS}

É com grande satisfação que manisfesto meu incessante agradecimento aos meus pais, João e Kenko, às minhas irmãs, Caroline e Carine, pela inspiração e paciência que conduzem ao meu aprimoramento profissional.

Expresso, também, meu obrigado ao Professor Dorel, pelo aprendizado adquirido ao longo da elaboração deste trabalho, sempre com muito profissionalismo, enorme prontidão e desafiadora orientação.

Aos meus amigos que me fazem persistir. 
"O pessimista queixa-se do vento, o otimista espera que ele mude e o realista ajusta as velas."

Willian George Ward 


\section{RESUMO}

A reestruturação do Setor Elétrico Brasileiro introduziu uma nova categoria de clientes no mercado consumidor. Os chamados Clientes Livres, ao contrário dos Clientes Cativos, podem formalizar a aquisição de energia elétrica para atendimento dos requisitos de seu processo produtivo, através de contratos bilaterais, onde os prazos, os preços e os volumes são livremente negociados entre os agentes.

A segmentação imposta pelas reformas do setor promoveu a competição na atividade de comercialização, repercutindo em novas responsabilidades para os agentes setoriais, com oportunidades para a busca de resultados financeiros, mas, por outro lado, com riscos associados que requerem adequado gerenciamento. Conseqüentemente, o estabelecimento de contratos neste ambiente evidencia a importância da adoção de estratégias de hedge adequadas para mitigar os riscos de exposição financeira dos Clientes Livres ao Mercado de Curto Prazo.

Sob essa perspectiva, o texto aborda a formação de preços contratuais no curto e longo prazos, propõe critérios de risco para aferir as estratégias mais promissoras, de acordo com o perfil do consumidor, de modo a otimizar a obtenção de energia no Ambiente de Contratação Livre, contemplando, também, o efeito da recente possibilidade da comercialização dos excedentes de energia elétrica, como forma de flexibilização contratual para esta categoria de consumidores.

Palavras-chave: Cessão de Excedentes Contratuais; Comercialização de Energia Elétrica; Consumidores Livres; Mercados de Energia Elétrica; Mitigação de Riscos; Preços Contratuais de Energia 


\begin{abstract}
The power sector reforms in Brazil introduced a new sort of consumers in the electricity market. The "Free Consumers" are able to choose their suppliers and freely negotiate contractual terms.
\end{abstract}

The restructuring process of electricity industry promoted the competition into the retail sales subindustry. It gave new responsibilities to market participants and also potential opportunities to reduce its energy costs. On the other hands, the "Free Customers" are requested to manage their own risks. It is important therefore the establishment of contracting strategies to hedge against price risks.

As consequence, the purpose of this study is to address a methodology to implement short and long-term contract pricing and evaluate the risks associated with its strategies. Moreover, the work identifies the contracting decisions to optimize electricity costs accordingly to customer's needs. Finally, it is presented a study on contract flexibility where an opportunity could be given to such kind of consumers, making possible to resell part of their electricity contracts.

Keywords: Contract Flexibility; Electricity Retail Sales; Freely Negotiate Contractual Terms; Electricity Market; Risk Mitigation; Electricity Contracts 


\section{LISTA DE ILUSTRAÇÕES}

Figura 3.1 - Segmentação nas atividades do setor elétrico ...................................... 6

Figura 3.2 - Ambientes de contratação de energia.................................................. 7

Figura 3.3 - Diagrama das instituições do setor elétrico............................................... 8

Figura 3.4 - Decisão de despacho de geração com o uso dos recursos hidrelétricos no presente versus armazenamento de água para geração futura de energia .................. 14

Figura 3.5 - Minimização do custo total de geração .................................................. 15

Figura 3.6 - O planejamento da operação eletroenergética ........................................ 16

Figura 5.1 - Estratégia de contratação baseada em uma única escolha no período de análise.

Figura 5.2 - Ingredientes da formação de preços contratuais 31

Figura 5.3 - Fluxograma de formação do preço dos contratos com 1 ano de duração 35

Figura 5.4 - Representação da escolha de hidrologias similares 39

Figura 5.5 - Fluxograma de formação do preço dos contratos com 2 anos de duração

Figura 5.6 - Fluxograma de formação do preço dos contratos com duração variando entre 3 e 5 anos

Figura 5.7 - Exemplo de distribuição normal de probabilidades para caracterizar o perfil de consumo de energia do Consumidor Livre....

Figura 5.8 - Fluxograma indicando a caracterização do perfil de consumo de energia do Consumidor Livre

Figura 5.9 - Exemplificação da cessão de excedente contratual adotando a hipótese (i) 
Figura 5.10 - Exemplificação da cessão de excedente contratual adotando a hipótese (ii)

Figura 5.11 - Exemplificação da cessão de excedente contratual adotando a hipótese (i) 57

Figura 5.12 - Exemplificação da cessão de excedente contratual adotando a hipótese (ii) 58

Figura 5.13 - Fluxograma da metodologia de cessão dos excedentes contratuais de energia 59

Figura 5.14 - Faixas de preços para o cálculo do risco de preços 61

Figura 5.15 - Renovação contratual e o preço do MWmed .......................................... 62

Figura 5.16 - Adicional contratual e o preço do MWmed............................................. 63 


\section{LISTA DE GRÁFICOS}

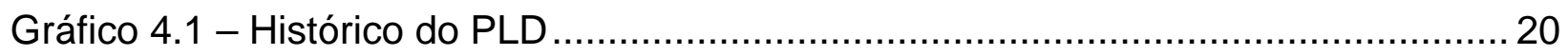

Gráfico 5.1 - Exemplificação do procedimento de formação do preço dos contratos com vigência de um ano... 36

Gráfico 5.2 - Exemplificação do procedimento de formação do preço dos contratos com vigência de dois anos

Gráfico 5.3 - Exemplificação do procedimento de formação do preço dos contratos com vigência de três ou mais anos.

Gráfico 5.4 - Exemplificação de perfil de consumo de energia do Consumidor Livre... 53

Gráfico 6.1 - Histograma das faixas de preços presentes no Cenário Favorável.

Gráfico 6.2 - Preços Médios nas distintas modalidades contratuais - Cenário Favorável

Gráfico 6.3 - Comportamento do risco ao longo do período para os contratos com um ano de duração e, variando-se o Preço Máximo Admissível (PMA) - Cenário Favorável

Gráfico 6.4 - Comportamento do risco ao longo do período para os contratos com cinco anos de duração e, variando-se o Preço Máximo Admissível (PMA) - Cenário Favorável

Gráfico 6.5 - Sensibilidade do risco dos contratos com a variação do Preço Máximo Admissível (PMA) - Cenário Favorável

Gráfico 6.6 - Histogramas das faixas de preços possíveis em cada modalidade contratual - Cenário Favorável.

Gráfico 6.7 - Contribuição das faixas de preços nos contratos de 3 anos com a variação do valor da Energia Nova - Cenário Favorável.

Gráfico 6.8 - Contribuição das faixas de preços nos contratos de 5 anos com a variação do valor da Energia Nova - Cenário Favorável... 
Gráfico 6.9 - Histograma das faixas de preços para o Cenário Escassez......

Gráfico 6.10 - Preços Médios nas distintas modalidades contratuais - Cenário Escassez....

Gráfico 6.11 - Comportamento do risco ao longo do período para os contratos com um ano de duração e, variando-se o Preço Máximo Admissível (PMA) - Cenário Escassez

Gráfico 6.12 - Comportamento do risco ao longo do período para os contratos com cinco anos de duração e, variando-se o Preço Máximo Admissível (PMA) - Cenário Escassez

Gráfico 6.13 - Sensibilidade do risco dos contratos com a variação do Preço Máximo Admissível (PMA) - Cenário Escassez.

Gráfico 6.14 - Histogramas das faixas de preços possíveis em cada modalidade contratual - Cenário Escassez

Gráfico 6.15 - Contribuição das faixas de preços nos contratos de 3 anos com a variação do valor da Energia Nova - Cenário Escassez

Gráfico 6.16 - Contribuição das faixas de preços nos contratos de 5 anos com a variação do valor da Energia Nova - Cenário Escassez

Gráfico 6.17 - Custo da energia nas distintas modalidades contratuais - cessão pelo limite - Cenário Favorável

Gráfico 6.18 - Preços Médios Máximos nas distintas modalidades contratuais e para um Preço Máximo Admissível (PMA) de 168 R $\$ / M W h$ - cessão pelo limite - Cenário Favorável

Gráfico 6.19 - Riscos médios de preços acima do PMA de $168 \mathrm{R} \$ / \mathrm{MWh}$ - cessão pelo limite - Cenário Favorável

Gráfico 6.20 - Riscos médios de preços acima do PMA de $240 \mathrm{R} \$ / \mathrm{MWh}$ - cessão pelo limite - Cenário Favorável

Gráfico 6.21 - Custo da energia nas distintas modalidades contratuais - cessão até o limite - Cenário Favorável 95 
Gráfico 6.22 - Preços Médios Máximos nas distintas modalidades contratuais e para um Preço Máximo Admissível (PMA) de 168 R \$/MWh - cessão até o limite - Cenário Favorável

Gráfico 6.23 - Riscos médios de preços acima do PMA de $168 \mathrm{R} \$ / \mathrm{MWh}$ - cessão até 0 limite - Cenário Favorável

Gráfico 6.24 - Riscos médios de preços acima do PMA de 240 R\$/MWh - cessão até o limite - Cenário Favorável

Gráfico 6.25 - Custo da energia mensal em uma modalidade contratual de curto prazo cessão até o limite - Cenário Favorável

Gráfico 6.26 - Custo da energia mensal em uma modalidade contratual de longo prazo - cessão até o limite - Cenário Favorável 101

Gráfico 6.27 - Os preços contratuais através do conceito de $V A R_{\text {mod }}$ cessão até o limite - Cenário Favorável. 104

Gráfico 6.28 - Custo da energia nas distintas modalidades contratuais - cessão até o limite - Cenário Escassez..

Gráfico 6.29 - Preços Médios Máximos nas distintas modalidades contratuais e para um Preço Máximo Admissível (PMA) de 168 R\$/MWh - cessão até o limite - Cenário Escassez.

Gráfico 6.30 - Riscos médios de preços acima do PMA de $168 \mathrm{R} \$ / \mathrm{MWh}$ - cessão até o limite - Cenário Escassez

Gráfico 6.31 - Riscos médios de preços acima do PMA de 240 R \$/MWh - cessão até o limite - Cenário Escassez

Gráfico 6.32 - Os preços contratuais através do conceito de $V A R_{\text {mod }}$ - cessão até o limite - Cenário Escassez 


\section{LISTA DE TABELAS}

Tabela 4.1 - Condições para poder optar pelo Mercado de Livre Contratação ............. 21

Tabela 6.1 - Valores correspondentes as faixas de preços das abcissas ...................74

Tabela 6.2 - Considerações sobre a expansão da oferta de energia para o Cenário

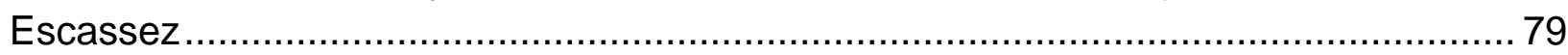




\section{LISTA DE ABREVIATURAS E SIGLAS}

ACL AMBIENTE DE CONTRATAÇÃO LIVRE

ACR AMBIENTE DE CONTRATAÇÃO REGULADA

ANEEL AGÊNCIA NACIONAL DE ENERGIA ELÉTRICA

CAR CURVA DE AVERSÃO AO RISCO

CCEAR CONTRATO DE COMERCIALIZAÇÃO DE ENERGIA ELÉTRICA EM AMBIENTE REGULADO

CCEE CÂMARA DE COMERCIALIZAÇÃO DE ENERGIA ELÉTRICA

CEPEL CENTRO DE PESQUISAS DE ENERGIA ELÉTRICA

CME CUSTO MARGINAL DE EXPANSÃO

CMO CUSTO MARGINAL DE OPERAÇÃO

CMSE COMITÊ DE MONITORAMENTO DO SETOR ELÉTRICO

CNPE CONSELHO NACIONAL DE POLÍTICAS ENERGÉTICAS

CNPJ CADASTRO NACIONAL DE PESSOA JURÍDICA

ENA ENERGIA NATURAL AFLUENTE

EPE EMPRESA DE PESQUISA ENERGÉTICA

FCF FUNÇÃO DE CUSTO FUTURO

FCl FUNÇÃO DE CUSTO IMEDIATO 


$\begin{array}{ll}\text { MAE } & \text { MERCADO ATACADISTA DE ENERGIA } \\ \text { MME } & \text { MINISTÉRIO DE MINAS E ENERGIA } \\ \text { ONS } & \text { OPERADOR NACIONAL DO SISTEMA ELÉTRICO } \\ \text { PCH } & \text { PEQUENAS CENTRAIS HIDRELÉTRICAS } \\ \text { PEN } & \text { PREÇO DA ENERGIA NOVA } \\ \text { PLD } & \text { PREÇO DE LIQUIDAÇÃO DE DIFERENÇAS } \\ \text { PMA } & \text { PREÇO MÁXIMO ADMISSÍVEL } \\ \text { PMM } & \text { PREÇO MÉDIO MÁXIMO } \\ \text { RM } & \text { RISCO MÉDIO } \\ \text { SIN } & \text { SISTEMA INTERLIGADO NACIONAL } \\ \text { VAR } & \text { VALUE AT RISK } \\ \text { VAR } & \text { VALUE AT RISK MODIFICADO }\end{array}$




\section{LISTA DE SÍMBOLOS}

c número da ordem referente ao contrato que compõe a carteira de contratos do Consumidor Livre

$\boldsymbol{C}_{1} \quad$ preço do contrato de 1 ano, $\mathrm{R} \$ / \mathrm{MWh}$

$C_{\text {final }} \quad$ custo final ao longo do horizonte de análise, $\mathrm{R} \$$, considerando os contratos de compra como os de venda de energia

$\boldsymbol{C}_{\text {mensal }} \quad$ custo de energia mensal, $\mathrm{R} \$$

$\boldsymbol{C}_{n} \quad$ preço do contrato de n anos, $\mathrm{R} \$ / \mathrm{MWh}$

$\boldsymbol{C}_{\text {total }} \quad$ custo total de energia durante o horizonte de análise, $\mathrm{R} \$$

D $\quad$ energia consumida, MWh

e número total de contratos excedentes que compõem a carteira de contratos do Consumidor Livre, referente ao mês em questão

$E_{a}$ tempo de atraso médio de início de um evento que afeta a demanda do consumidor

$E C_{c}$ montante de energia comprado no c-ésimo contrato que compõe a carteira de contratos do Consumidor Livre, MWh

$E C_{c, m}$ montante de energia comprado, em MWh, no m-ésimo mês calendário do horizonte de análise, relativo ao c-ésimo contrato constituinte da carteira de contratos do Consumidor Livre

$E_{d} \quad$ duração média da redução de consumo 
$E_{r} \quad$ a redução média do consumo

$E V_{c}$ montante de energia vendida no c-ésimo contrato excedente que compõe a carteira de contratos do Consumidor Livre, MWh

$E V_{c, m} \quad$ montante de energia vendida, em MWh, no m-ésimo mês calendário do horizonte de análise, relativo ao c-ésimo contrato excedente constituinte da carteira de contratos do Consumidor Livre

f fator de similaridade para definição das hidrologias aceitáveis (p.u.)

i taxa de desconto mensal

IC intervalo de confiança

IP intervalo de precisão

$\boldsymbol{k} \quad$ número da ordem referente à série hidrológica pertencente ao conjunto ordenado dos episódios hidrológicos que provocam valores de PLD satisfazendo a equação (2)

Lm número de ordem da série hidrológica com menor preço spot médio para o $2^{\circ}$ ano, que ainda supera o valor mínimo admitido como critério na equação (2)

LM número de ordem da série hidrológica com maior preço spot médio para o $2^{\circ}$ ano, que ainda não supera o valor máximo admitido como critério na equação (2)

$\boldsymbol{m} \quad$ número da ordem referente ao mês do ano

$\boldsymbol{N}$ número de ocorrências que forma o universo dos dados para a determinação das distribuições normais de probabilidade 
$\boldsymbol{n}$ número total de contratos que compõem a carteira de contratos do Consumidor Livre, referente ao mês em questão

$\boldsymbol{P} \quad$ preço do contrato de energia, $\mathrm{R} \$ / \mathrm{MWh}$

p.u. $\quad$ valor por unidade (valor percentual / 100)

$\boldsymbol{P}_{2} \quad$ preço que irá vigorar durante o segundo ano de cobertura do contrato, $\mathrm{R} \$ / \mathrm{MWh}$

$\boldsymbol{P}_{2 L P} \quad$ preço de longo prazo representativo do $2^{\circ}$ ano de contrato, $\mathrm{R} \$ / \mathrm{MWh}$, sendo este, um mix de ofertas com maior prazo de contratação e coerentes com entrega em dois anos como: Leilões de Energia Existente (A-1), Leilões de Ajuste e Geração Distribuída

$\boldsymbol{P}_{2 s} \quad$ preço de curto prazo representativo do $2^{\circ}$ ano de contrato, $\mathrm{R} \$ / \mathrm{MWh}$

$P_{c} \quad$ preço de compra do c-ésimo contrato que compõe a carteira de contratos do Consumidor Livre, $\mathrm{R} \$ / \mathrm{MWh}$

$\boldsymbol{P C}_{c, \boldsymbol{m}} \quad$ preço de compra no m-ésimo mês calendário do horizonte de análise, relativo ao c-ésimo contrato constituinte da carteira de contratos do Consumidor Livre, $\mathrm{R} \$ / \mathrm{MWh}$

$\boldsymbol{P}_{\boldsymbol{k}} \quad$ preço médio do ano a frente do instante de recontratação, $\mathrm{R} \$ / \mathrm{MWh}$, calculado pelas equações (1) e (3)

$\boldsymbol{P}_{\text {MWmed }} \quad$ preço do megawatt médio, $\mathrm{R} \$ / \mathrm{MWh}$

$\boldsymbol{P V}_{\boldsymbol{c}} \quad$ preço de venda do c-ésimo contrato excedente que compõe a carteira de contratos do Consumidor Livre, $\mathrm{R} \$ / \mathrm{MWh}$ 
$\boldsymbol{P} \boldsymbol{V}_{c, \boldsymbol{m}} \quad$ preço de venda no m-ésimo mês calendário do horizonte de análise, relativo ao césimo contrato excedente constituinte da carteira de contratos do Consumidor Livre, $\mathrm{R} \$ / \mathrm{MWh}$

$\boldsymbol{R}_{\text {mensal }} \quad$ receita com venda de energia excedente mensal, $\mathrm{R} \$$

$\boldsymbol{R}_{\text {total }} \quad$ receita total com venda de energia excedente durante o horizonte de análise, $\mathrm{R} \$$

Spot $_{m, k} \quad$ preço spot mensal do m-ésimo mês calendário do $2^{\circ}$ ano de contrato, relativo à késima série hidrológica selecionada por critério de similaridade, $\mathrm{R} \$ \mathrm{MWh}$

SpotMed $_{m}$ preço spot médio mensal, $\mathrm{R} \$ / \mathrm{MWh}$, do m-ésimo mês calendário, relativo ao ano no qual irá vigorar o contrato, considerando a média do conjunto de séries hidrológicas do Histórico (ou Sintéticas)

$V \boldsymbol{d}_{k} \mathbf{2}^{\circ}$ ano valor médio dos preços mensais para a k-ésima série hidrológica considerada na simulação, para o segundo ano de contrato, $\mathrm{R} \$ / M W h$

Vdo1ano valor baseado no preço do contrato para o $1^{\circ}$ ano ut ilizado na equação (1)

$\boldsymbol{x} \quad$ valor por unidade (valor percentual / 100) de tal forma a ponderar os preços que formarão o segundo ano de cobertura do contrato

$\boldsymbol{\sigma}_{E a}$ desvio padrão do tempo de atraso médio de início de um evento que afeta a demanda do consumidor

$\sigma_{E d} \quad$ desvio padrão da duração média da redução de consumo

$\sigma_{E r} \quad$ desvio padrão da redução média do consumo 


\section{SUMÁRIO}

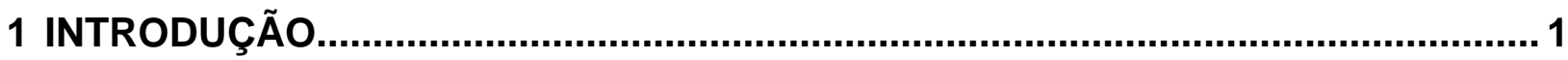

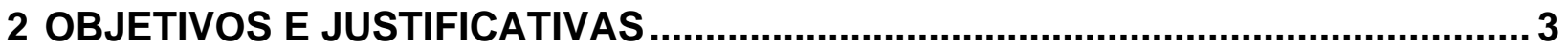

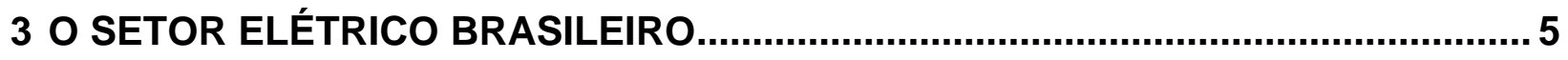

3.1. O MODELO INSTITUCIONAL .................................................................... 5

3.2. O PLANEJAMENTO DA OPERAÇÃO ELETROENERGÉTICA ................................11

3.2.1. O custo marginal de operação ......................................................................................... 12

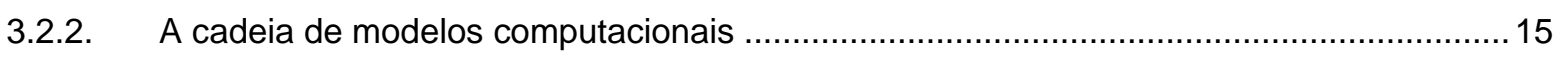

4 FORMAÇÃO DE PREÇOS EM MERCADOS DE ENERGIA ELÉTRICA ..................18

4.1. A VOLATILIDADE DOS PREÇOS DE CURTO PRAZO …...................................20

4.2. O MERCADO DE LIVRE CONTRATAÇÃO DE ENERGIA ....................................21

5 PREMISSAS, CONCEITOS E METODOLOGIA PARA O DESENVOLVIMENTO DA

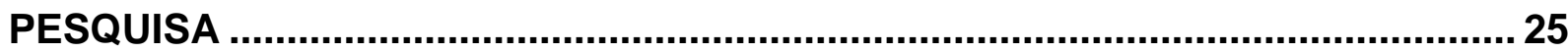

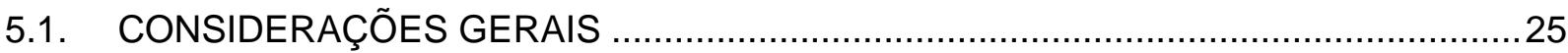

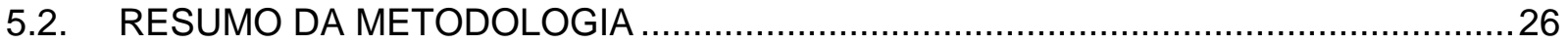

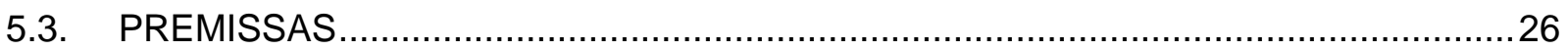

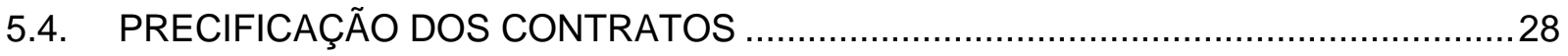

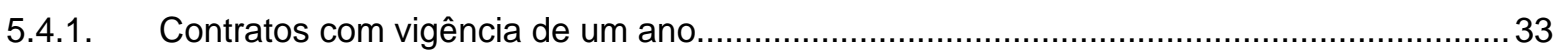

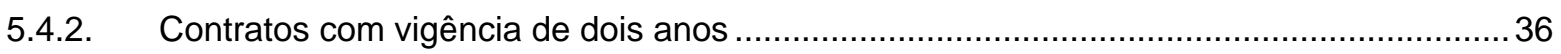

5.4.3. Contratos com vigência de três, quatro e cinco anos .................................................... 44

5.4.4. Contratos com vigência fracionária............................................................................ 47

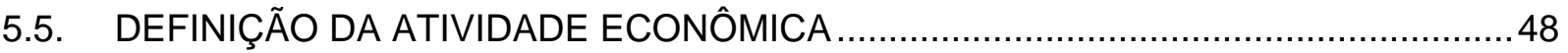

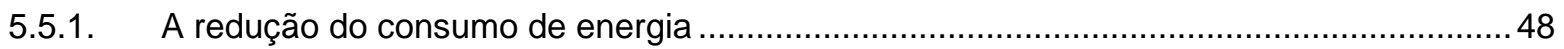

5.5.2. A duração da redução de consumo de energia .............................................................. 48

5.5.3. O tempo até a ocorrência do evento que provoca a redução de consumo de energia....... 49

5.5.4. Caracterização do perfil de consumo de energia do Consumidor Livre ............................. 49

5.6. A CESSÃO DOS EXCEDENTES CONTRATUAIS E SUA PRECIFICAÇÃO...............53

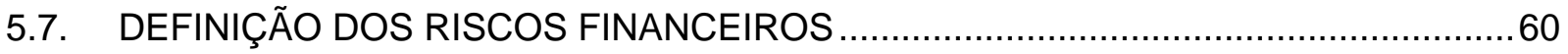

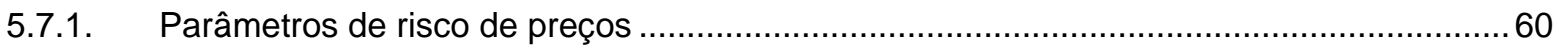

5.7.2. Definição do preço dos contratos ponderado pelo MWmed ...........................................61

5.7.3. Definição do conceito de Value at Risk Modificado ........................................................ 64 
5.7.4. Definição do custo de aquisição de energia ............................................................ 65

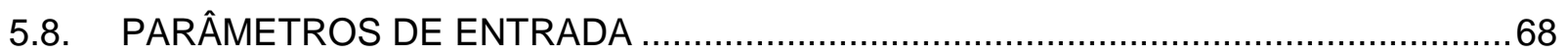

5.8.1. Preços spot gerados a partir do software NEWAVE....................................................... 68

5.8.2. Horizonte temporal para a simulação da contratação ................................................... 68

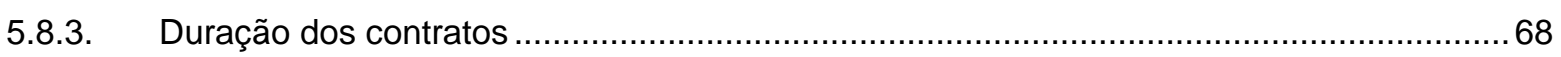

5.8.4. Taxa anual de atualização do capital........................................................................ 69

5.8.5. Fator de abertura para escolha das séries de preços similares ......................................... 69

5.8.6. Ponderação de preços para formar o segundo ano de vigência dos contratos .................69

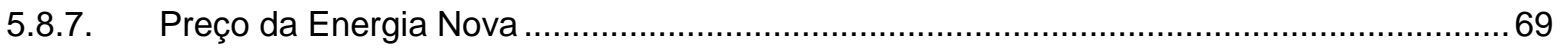

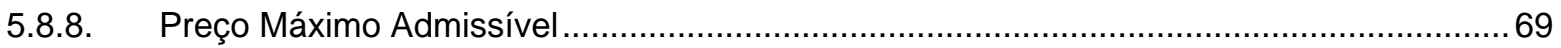

5.8.9. Distribuição normal de probabilidade: redução do consumo de energia........................... 70

5.8.10. Distribuição normal de probabilidade: duração da redução de consumo de energia.........70

5.8.11. Distribuição normal de probabilidade: tempo até a ocorrência do evento que provoca a

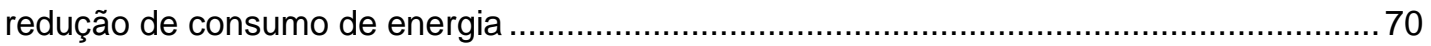

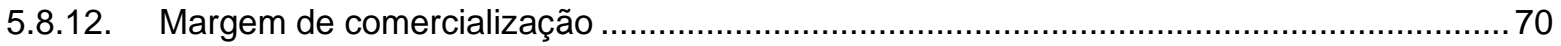

5.8.13. Energia consumida pelo Consumidor Livre …........................................................... 70

5.8.14. Limites de cessão dos excedentes contratuais ........................................................... 70

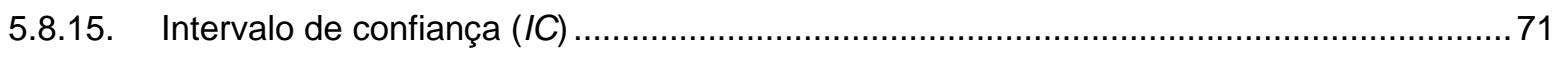

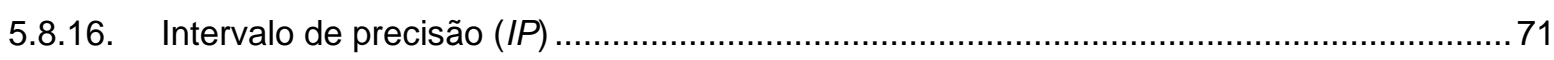

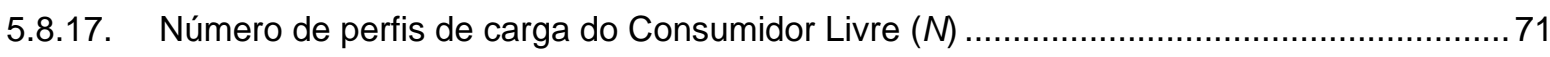

6 RESULTADOS OBTIDOS NAS SIMULAÇÕES....................................................... 72

6.1. OS PREÇOS CONTRATUAIS E SEUS RISCOS............................................. 72

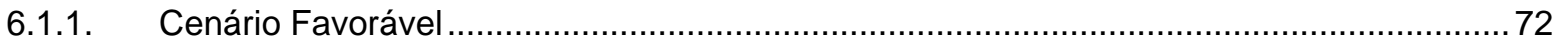

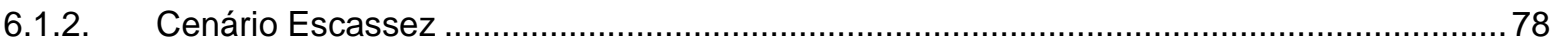

6.2. O EFEITO DA CESSÃO DOS EXCEDENTES CONTRATUAIS ...............................84

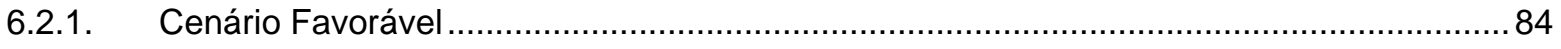

6.2.1.1. Cessão de excedentes pelo limite previsto na modalidade contratual ........................... 84

6.2.1.2. Cessão de excedentes até o limite previsto na modalidade contratual..........................94

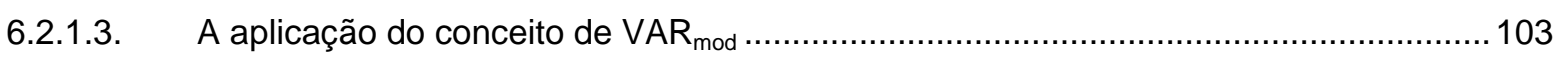

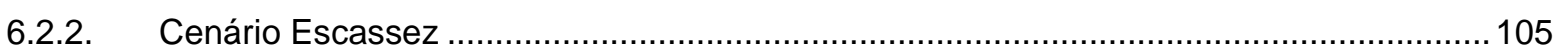

6.2.2.1. Cessão de excedentes até o limite previsto na modalidade contratual........................ 105

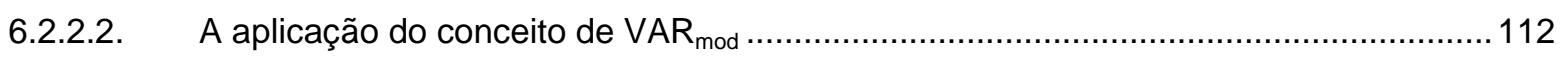

7 CONCLUSÕES............................................................................................... 115

8 REFERÊNCIAS BIBLIOGRÁFICAS ........................................................... 119 


\section{INTRODUÇÃO}

O recurso energia elétrica é um dos principais mantenedores do desenvolvimento econômico de um país. Destarte, a abrangência de sua utilização baliza índices para a comparação de níveis de progresso sócio-econômico entre Nações.

O emprego deste insumo é fundamental em qualquer setor da economia, recebendo especial atenção no ramo industrial, no qual uma estruturação regulatória apropriada do setor de energia, com vistas ao aumento da eficiência, certamente, é um fator decisivo para a competitividade das empresas, principalmente naquelas em que a utilização da energia elétrica é parte significativa na composição dos custos de seus processos produtivos.

Para atender as exigências tanto técnicas, econômicas e sociais demandadas pela complexidade das relações identificadas entre os atores presentes na produção, transmissão, distribuição, comercialização e uso do produto energia elétrica, foi reformulado o modelo do Setor Elétrico Brasileiro.

O modelo vigente do Setor Elétrico visa definir diretrizes para harmonizar a atuação dos diversos agentes setoriais (geradoras, transmissoras, distribuidoras, comercializadoras e consumidores) e instituições frente à sua constante reestruturação e adaptação às realidades do mercado de energia elétrica.

Conseqüentemente, o trato pelos agentes do mercado dessa especial commodity vem sofrendo constantes atualizações visando otimizar a sua cadeia de suprimento. 
É nesse contexto que surge este documento para analisar, com especial ênfase, as estratégias de comercialização de energia para os Consumidores Livres no âmbito do Setor Elétrico Brasileiro.

Nesse âmbito de considerações, são contempladas alternativas para obtenção do necessário suprimento de energia aos Consumidores Livres, buscando-se definir qual a melhor combinação das variáveis chave da contratação, ou seja, volume, preço e prazo. Por conseguinte, estratégias de contratação de energia a partir de contratos de curto, médio e longo prazos são comparadas, incluindo a aferição do potencial de mitigação de riscos de mercado oferecido por recente dispositivo regulatório, em fase de regulamentação por parte do $\mathrm{MME}$, que permite a venda de excedentes de contrato, quando ocorrem situações de redução persistente de consumo, com percentuais variáveis e tanto maiores quanto maior o prazo de contratação'.

\footnotetext{
${ }^{1}$ Esta diretriz do regulamento sendo implementado objetiva incentivar a contratação de longo prazo por parte dos Consumidores Livres, que rebate em benefícios para a expansão do sistema (contratos longos podem ser utilizados como garantia de financiamento - PPA "Power Purchase Agreements" - pelos agentes geradores), na medida em que mitiga parcela substancial dos riscos financeiros do Consumidor que, tendo assumido contrato de longo prazo, se defronte com redução prolongada de consumo, em face de adversidades da conjuntura econômica e, sem opção, tivesse que vender seus excedentes apenas no mercado de curto prazo. Ressalte-se, por oportuno, que a aferição da eficácia e eficiência do mecanismo citado é um dos principais objetivos da presente pesquisa de Mestrado.
} 


\section{OBJETIVOS E JUSTIFICATIVAS}

O remodelamento do Setor Elétrico Brasileiro instituiu o Ambiente de Contratação Livre - ACL. O presente texto objetiva analisar os custos de aquisição de energia elétrica, neste segmento de mercado, através de uma metodologia de precificação de contratos e, também, de avaliação dos riscos associados às modalidades contratuais de compra deste insumo em distintos cenários macro-econômicos, que condicionam as condições de balanço de oferta e demanda no Sistema Interligado Nacional - SIN, com rebatimento na fixação dos preços para contratação tanto de curto (entre um e dois anos de vigência), quanto de médio / longo prazo (entre três e cinco anos de vigência).

Na seqüência, o trabalho aborda a eficácia da contratação de longo prazo para mitigar os riscos de exposição financeira aos preços praticados no Mercado de Curto Prazo.

Finalmente, é estudada a comercialização de excedentes de energia elétrica por parte dos Consumidores Livres como forma de flexibilização contratual com vistas à otimizar a compra deste insumo dentro de um horizonte de longo prazo.

Cabe salientar, que a abordagem do tema "comercialização de excedentes contratuais" visa aferir a importância deste instrumento contratual, focado na adaptação de demanda do Consumidor Livre às circunstâncias vigentes no seu mercado. Posto desta maneira, o cliente ao optar pelo Ambiente de Contratação Livre, almeja não somente a liberdade de escolha do seu fornecedor de energia elétrica, mas também, a possibilidade de gerenciar seus contratos de fornecimento deste importante insumo, de modo a contemplar suas necessidades energéticas dentro do horizonte de vigência dos seus contratos. 
Um aspecto que não pode ser negligenciado diz respeito à imprevisibilidade de eventos externos que possam afetar o seu consumo de forma conjugada com reajustes de preços contratuais, baseados em índices de preços ou indexadores cambiais pósfixados, em conjunturas econômicas desfavoráveis, com severo impacto sobre os resultados financeiros da empresa consumidora.

Esse tipo de evento reforça ainda mais a importância da flexibilização contratual como mecanismo de promoção da alocação eficiente dos montantes de energia contratados e, consequentemente, da competitividade da indústria nacional no tocante à otimização dos custos que impactam os seus processos produtivos. Nesse caso, a venda de excedentes, ainda que não permita mitigar reajustes desfavoráveis de preços, posto que os contratos permanecem válidos e o consumidor em questão continua responsável pelo pagamento do volume integral do contrato ao vendedor e pelo preço pactuado, ao menos permite minimizar as conseqüências financeiras que poderiam ser desastrosas para a saúde financeira da empresa afetada. 


\section{O SETOR ELÉTRICO BRASILEIRO}

A partir da década de noventa, iniciou-se no Brasil a reestruturação do Setor Elétrico, cujo modelo institucional baseava-se em um padrão verticalizado e de predomínio estatal nas atividades relacionadas à geração, transmissão e distribuição de energia elétrica.

A reforma era necessária em virtude, principalmente, da insuficiência de recursos por parte do Estado para os devidos investimentos na expansão da oferta de energia em concordância com o crescimento da demanda do país.

Desta maneira, as diretrizes para a reforma do modelo do setor buscavam assegurar o adequado desenvolvimento da oferta de energia, promovendo a garantia na alocação eficiente dos recursos financeiros, na confiabilidade no fornecimento de energia e na modicidade tarifária.

\subsection{O MODELO INSTITUCIONAL}

A transição desta estrutura, predominantemente estatal, para um ambiente de mercado, foi sustentada pelo propósito de desmembramento dos segmentos de geração, transmissão, distribuição e comercialização de energia. A competição foi promovida nas atividades de geração e comercialização, enquanto que, de outro lado, houve a manutenção de monopólios naturais para prestação de serviços relacionados aos segmentos de transmissão e distribuição, com livre acesso às redes de transporte de energia, de acordo com a Figura 3.1. 


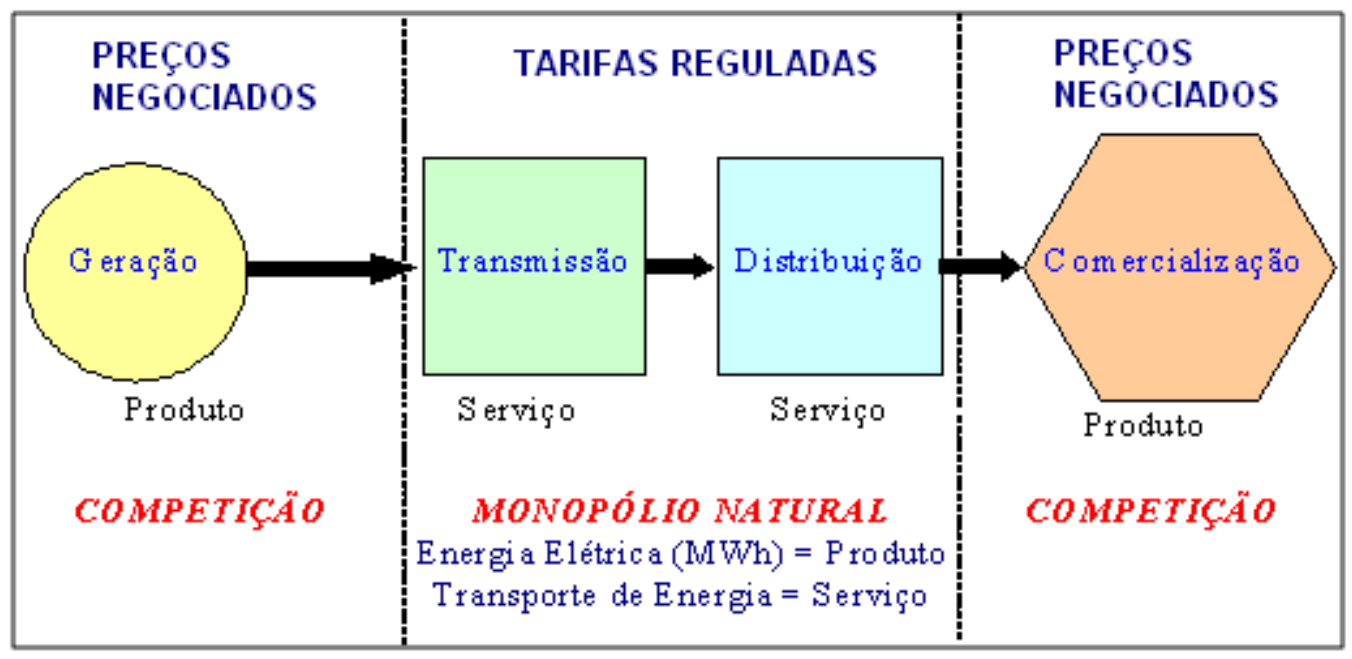

Figura 3.1 - Segmentação nas atividades do setor elétrico

Em complemento à desverticalização das atividades e do incentivo à entrada de capital privado no setor, identificou-se a necessidade da criação de instituições independentes com distintas funções: um órgão fiscalizador e regulador, a Agência Nacional de Energia Elétrica - ANEEL, um operador do sistema elétrico, o Operador Nacional do Sistema Elétrico - ONS e, por fim, um ambiente para a realização das transações de compra e venda de energia elétrica, o Mercado Atacadista de Energia - MAE.

Após as reformulações da década de noventa e, em virtude do racionamento de energia vivenciado durante o ano de 2001, um novo ciclo de reformas foi implementado, com alterações relevantes no modelo de comercialização de energia, onde foi instituída a Câmara de Comercialização de Energia Elétrica - CCEE, sucessora do MAE, para registro e contabilização da totalidade dos contratos de energia elétrica, sendo estes destinados a dois ambientes de mercado distintos: 
- Ambiente de Contratação Regulada - ACR, para atendimento dos consumidores cativos das distribuidoras, no qual a contratação é formalizada por meio de contratos bilaterais entre os agentes vendedores (geradores, produtores independentes ou autoprodutores) e compradores (distribuidoras) que participam de leilões de energia realizados pelo governo, nos quais a energia é adquirida pela menor tarifa. Os agentes de distribuição têm a obrigatoriedade da contratação da totalidade de seu mercado consumidor, de acordo com a Figura 3.2.

- Ambiente de Contratação Livre - ACL, para atendimento de consumidores livres e no qual a contratação é formalizada por meio de contratos bilaterais, com critérios livremente negociados entre os agentes de geração, comercialização, importadores e exportadores de energia, de acordo com a Figura 3.2.

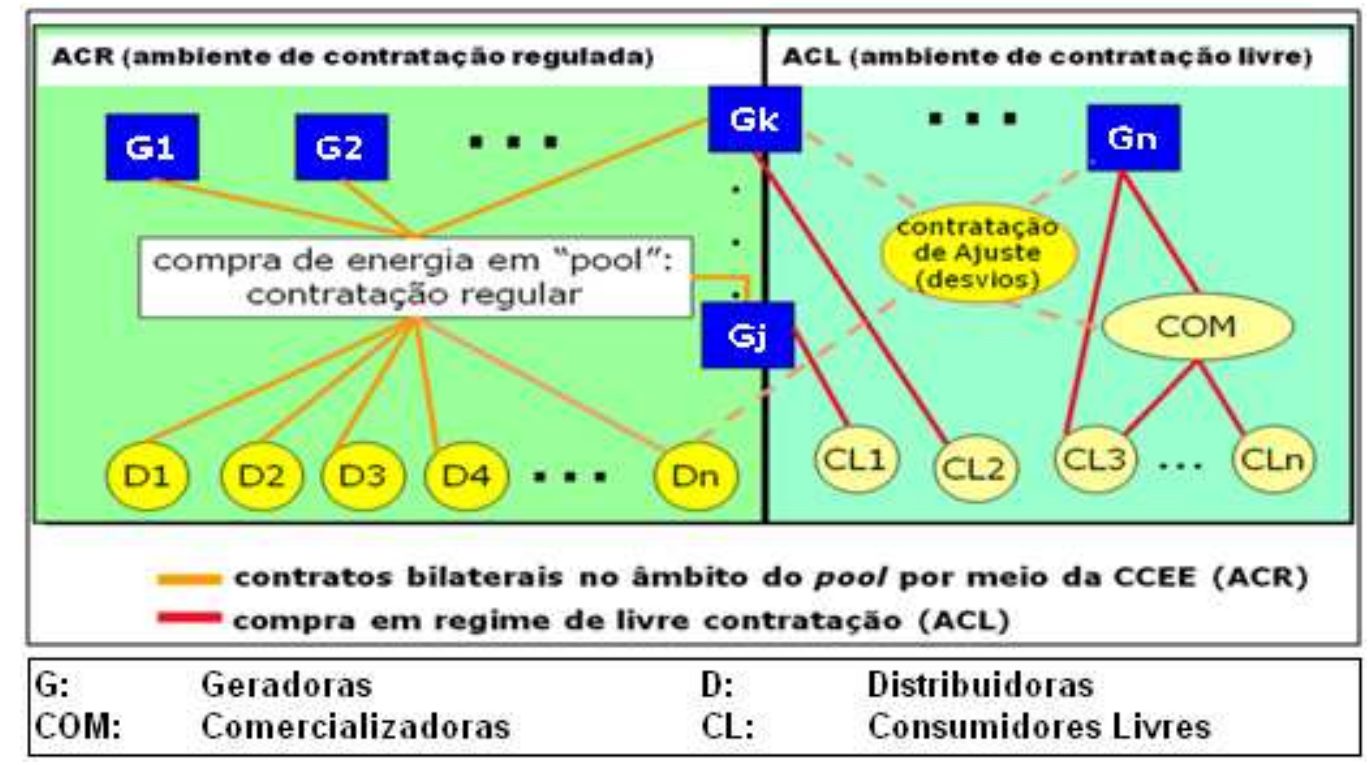

Figura 3.2 - Ambientes de contratação de energia 
Neste novo modelo foram criadas, também, a Empresa de Pesquisa Energética - EPE responsável pelo planejamento do setor energético de longo prazo e o Comitê de Monitoramento do Setor Elétrico - CMSE, responsável por avaliar permanentemente a segurança do suprimento de energia elétrica.

Atualmente, o diagrama das instituições presentes no setor está representado na Figura 3.3, sendo apresentado, na seqüência, uma síntese de suas respectivas atribuições.

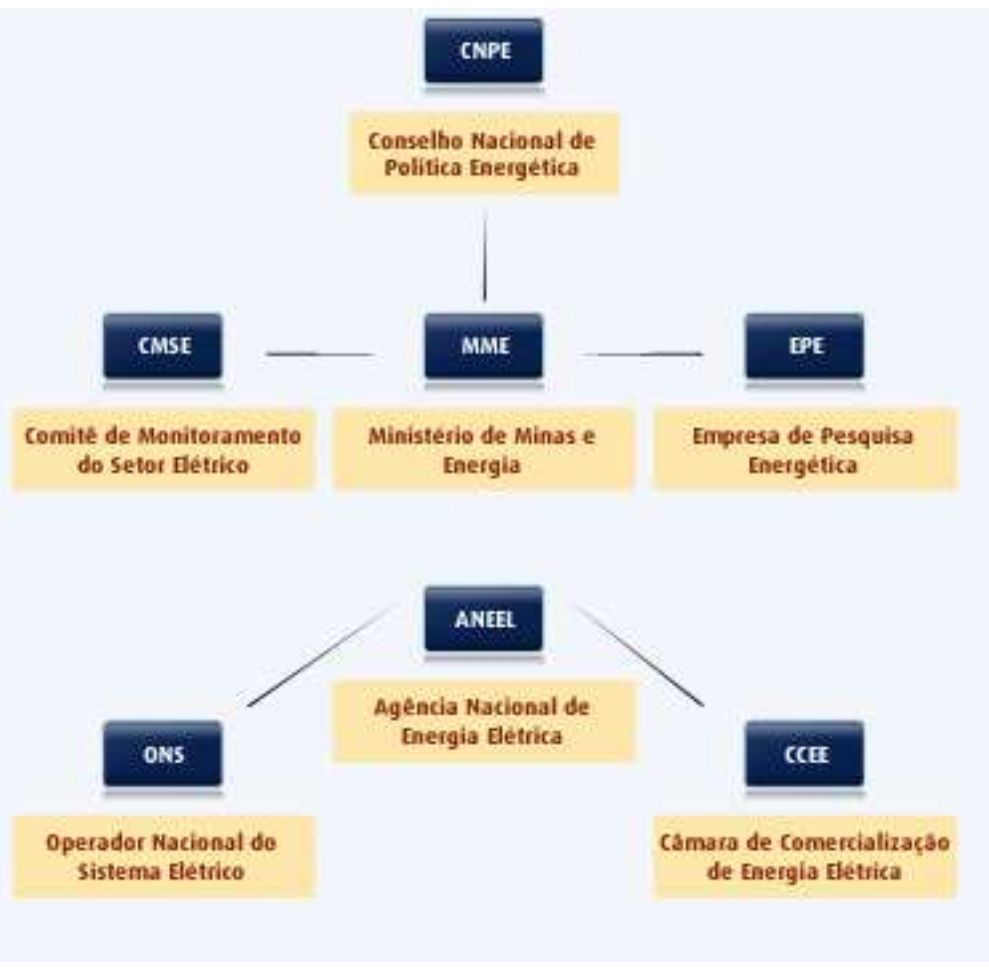

Figura 3.3 - Diagrama das instituições do setor elétrico ${ }^{2}$

${ }^{2}$ CÂMARA DE COMERCIALIZAÇÃO DE ENERGIA ELÉTRICA. 


\section{Conselho Nacional de Políticas Energéticas - CNPE}

Órgão interministerial de assessoramento à Presidência da República. Sua principal atribuição é a formulação de políticas e diretrizes de energia, assegurando o suprimento de insumos energéticos nas áreas mais remotas ou de difícil acesso do País. Sua responsabilidade também engloba revisar periodicamente as matrizes energéticas das diversas regiões do País, além de estabelecer diretrizes para a importação e exportação de petróleo e gás natural.

\section{Ministério de Minas e Energia - MME}

O Ministério de Minas e Energia é o órgão do Governo Federal responsável pela condução das políticas energéticas do País. É deste órgão a responsabilidade de formular e implementar as políticas para o setor energético, adotando as diretrizes definidas pelo CNPE. O MME é também responsável por estabelecer o planejamento do setor energético nacional, monitoração do suprimento do setor elétrico brasileiro e definir as ações preventivas para restauração da segurança de suprimento no caso de desequilíbrios conjunturais entre oferta e demanda de energia.

\section{Comitê de Monitoramento do Setor Elétrico - CMSE}

Este comitê é responsável por monitorar a geração, transmissão, distribuição, comercialização, importação e exportação de energia elétrica, acompanhando a continuidade e a segurança do fornecimento de energia elétrica brasileiro. 
O CMSE avalia a condição do sistema elétrico nacional, realizando de forma periódica a análise das dificuldades e problemas que possam prejudicar a expansão do setor, as condições de fornecimento e atendimento, propondo ações que visem assegurar o fornecimento de energia elétrica.

\section{Empresa de Pesquisa Energética - EPE}

Este órgão é responsável pela realização de estudos que propiciem o planejamento do uso de recursos energéticos de curto, médio e longo prazo e, também, da expansão do sistema elétrico nacional. Além disso, tem por atribuição gerar análises de viabilidade técnico-econômica e sócio ambiental de usinas.

\section{Agência Nacional de Energia Elétrica - ANEEL}

A Agência Nacional de Energia Elétrica é o órgão regulador do setor elétrico. Suas funções são de regular e fiscalizar a produção, transmissão, distribuição e comercialização da energia elétrica, sempre visando à qualidade dos serviços oferecidos e protegendo o consumidor final, ditando as regras de formulação do custo de energia elétrica.

\section{Operador Nacional do Sistema Elétrico - ONS}

O Operador Nacional do Sistema Elétrico é responsável por gerenciar o fornecimento de energia elétrica do Brasil. É este órgão que define o despacho das hidroelétricas, termoelétricas e de outros meios de geração, atendendo aos requisitos de carga e confiabilidade do Sistema Interligado Nacional - SIN. 


\section{Câmara de Comercialização de Energia Elétrica - CCEE}

A CCEE foi criada, em substituição ao MAE, na reformulação do setor energético, sendo responsável pela contabilização do total da energia comercializada, apurando o custo da energia elétrica no curto prazo, além de realizar a liquidação financeira das transações de compra e venda de energia no mercado de curto prazo.

Esta instituição, também, implementa os leilões de compra e venda de energia elétrica existentes no Ambiente de Contratação Regulado - ACR, por delegação da ANEEL.

\subsection{O PLANEJAMENTO DA OPERAÇÃO ELETROENERGÉTICA}

O Parque Gerador Brasileiro é composto, majoritariamente, por usinas hidrelétricas, que são responsáveis por cerca de $80 \%$ da capacidade instalada, com reservatórios de regularização plurianual até passado relativamente recente, mas que, em função da expansão termelétrica vigorosa nos últimos anos e a implementação de novas hidrelétricas apenas do tipo "fio d'água", vem perdendo expressão e hoje em dia já se verifica uma possibilidade de regularização apenas anual. Em função da extensão do território brasileiro, a estrutura do sistema tronco é complementada por longas linhas de transmissão interligando os grandes subsistemas regionais.

Nos momentos em que as hidrologias são favoráveis, o parque hidráulico pode produzir mais que sua energia assegurada, permitindo que o mercado seja atendido, preferencialmente, por essa forma de geração, reduzindo o custo global de operação do sistema na medida em que as termelétricas flexíveis podem ter seu despacho substancialmente reduzido, poupando combustível. 
Esta modalidade de operação é denominada de "Operação em Complementação Térmica", ou seja, as outras formas de geração são mais solicitadas a operar em períodos hidrológicos desfavoráveis, quando o nível dos reservatórios é insuficiente para atender a carga, ou ainda pode ser necessário acionar termelétricas para complementação de potência no horário de ponta. O suprimento de energia por outras fontes, que não a hidráulica portanto, se faz necessário para o restabelecimento dos níveis dos reservatórios das usinas hidrelétricas ou mesmo para resguardar níveis de reserva que estejam sendo registrados, como precaução contra uma futura conjuntura hidrológica adversa e, deste modo, prezar pela manutenção dos critérios de segurança no atendimento da demanda previstos pelo planejamento operativo do SIN.

Em virtude da predominância da geração hidráulica no fornecimento de energia elétrica, optou-se no Brasil, pela programação eletroenergética de despacho centralizado das usinas integrantes do Sistema Interligado Nacional. Sob essa configuração, cabe ao ONS a responsabilidade de operar as usinas do parque gerador nacional, subsidiada por modelos computacionais de otimização do uso da água armazenada nos reservatórios, moldando as estratégias de geração das usinas que minimizem o custo marginal de operação do SIN.

\subsubsection{O custo marginal de operação}

O Custo Marginal de Operação - CMO é definido como o custo incorrido para atender o aumento incremental na demanda por energia do Sistema Interligado Nacional e seu valor é expresso em $\mathrm{R} \$ / \mathrm{MWh}$. 
Para se aferir o custo de operação do sistema, diferentemente de sistemas puramente térmicos, em que o despacho ideal depende da capacidade de geração das usinas termelétricas e dos seus respectivos custos de combustível, o SIN tem seu custo operacional vinculado à sua estratégia de despacho.

Deste modo, a operação eletro-energética do SIN traduz as características inerentes aos sistemas hidrotérmicos de despacho centralizado, sendo de relevância destacar :

- Acoplamento temporal - a água armazenada nos reservatórios pode ser alocada à produção futura de energia, substituindo-se os custos de combustível das termelétricas. Ou seja, existe vinculação entre uma decisão tomada em um estágio no tempo e sua conseqüência futura.

- Natureza estocástica - impossibilidade de uma perfeita previsão das energias afluentes futuras, uma vez que estas são dependentes das condições hidrológicas futuras.

a Grande porte e acoplamento espacial - o sistema elétrico é formado por múltiplos reservatórios e com capacidades distintas, além disso, suas operações são dependentes da disponibilidade de energia de outras usinas, quando estas estão localizadas no mesmo aproveitamento de bacias hidrográficas.

C Comportamento não-linear - para as funções que representam a produção das hidrelétricas e os custos de operação das termelétricas.

Usos múltiplos da água - fator que afeta a disponibilidade hidráulica quando da utilização deste recurso para outros fins, tais como, navegação e irrigação. 
Neste contexto, o dilema existente na operação do sistema hidrotérmico, onde uma decisão tomada no presente sobre a utilização de recursos hidrelétricos, tem impactos sobre a disponibilidade desse bem no futuro, está representado no diagrama da Figura 3.4 .

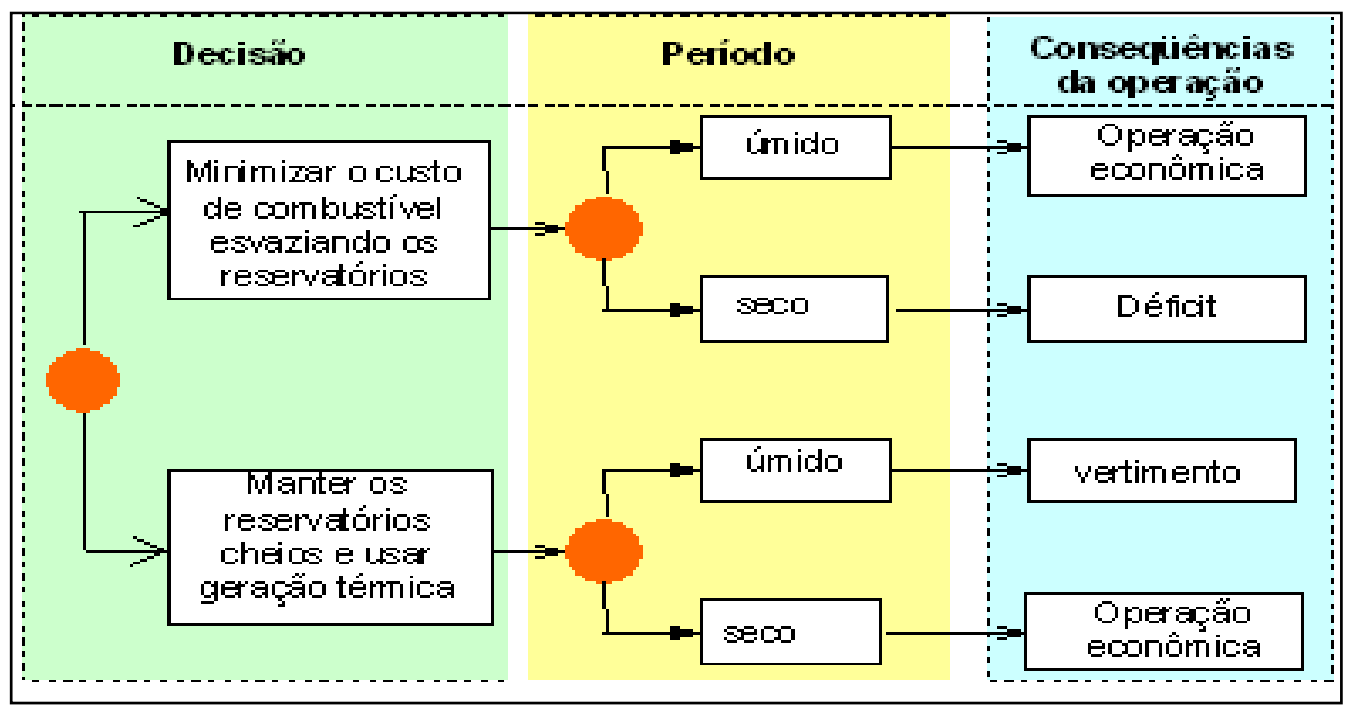

Figura 3.4 - Decisão de despacho de geração com o uso dos recursos hidrelétricos no presente versus armazenamento de água para geração futura de energia

Os custos de operação são dependentes da estratégia adotada para o despacho, de maneira que existe a possibilidade de utilização imediata da energia hidráulica armazenada ou economizá-la para geração futura de energia.

Essa dinâmica de decisões é traduzida pela composição de uma função de custo de operação que considera duas parcelas, sendo a primeira imediata, chamada de Função de Custo Imediato - FCl, refletindo os benefícios de uso imediato da água, e a segunda futura, chamada de Função de Custo Futuro - FCF, representando o custo de oportunidade do uso da água como benefício de seu armazenamento e, consequente geração de energia no futuro, conforme ilustra a Figura 3.5. 


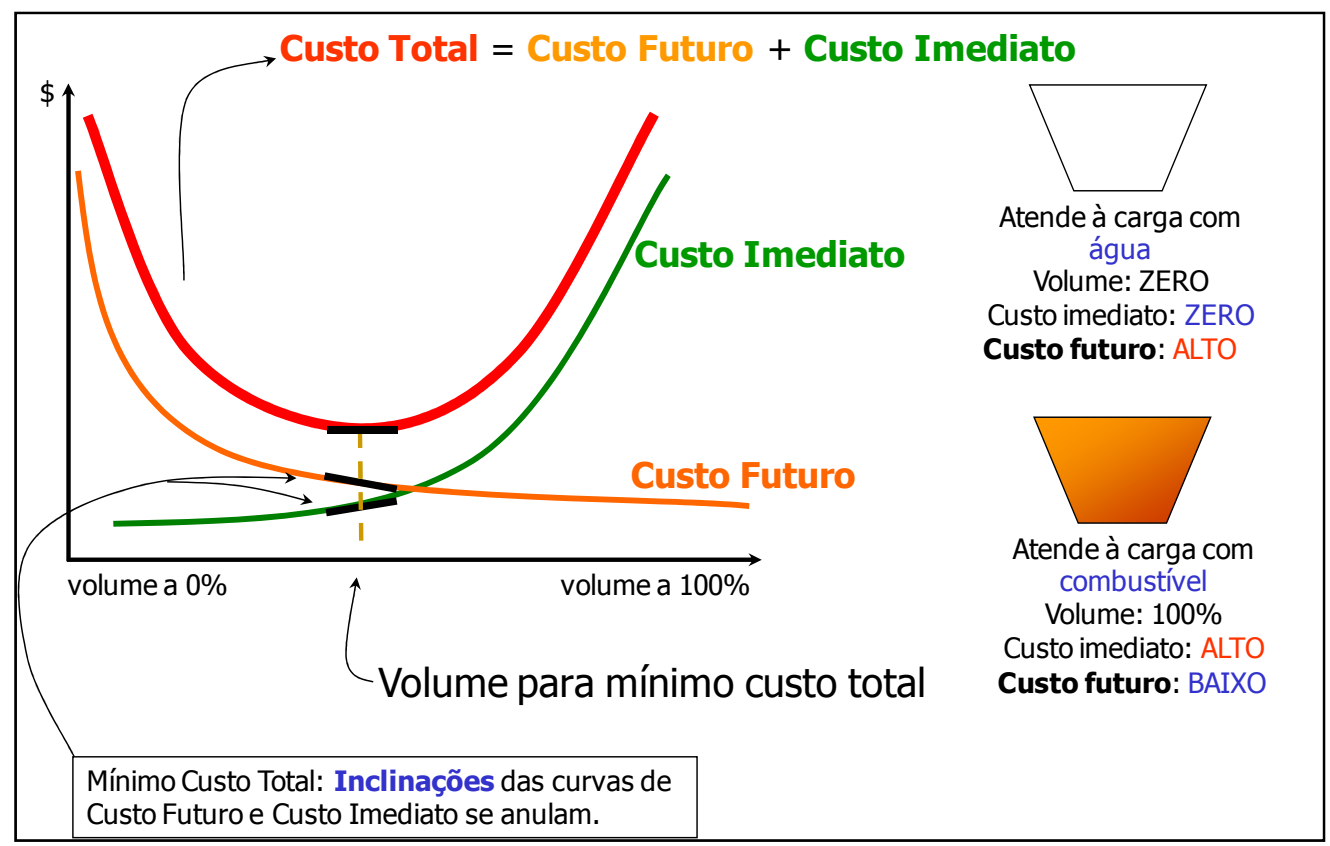

Figura 3.5 - Minimização do custo total de geração ${ }^{3}$

Dessa forma, conclui-se que o uso ótimo da água é aquele que minimiza a soma do custo de geração térmica no presente e o valor esperado do custo de geração desta fonte até o fim do período de estudo, traduzido pelo ponto de mínimo da curva apontada na Figura 3.5.

\subsubsection{A cadeia de modelos computacionais}

Fundamentalmente, os valores do custo marginal de operação são associados aos seguintes parâmetros: (i) energia hidráulica armazenada, representada pelo nível de armazenamento dos reservatórios; (ii) vazão afluente anterior, que reflete os registros hidrológicos no período que antecede a simulação da função de custo do sistema; (iii) previsão de carga; (iv) expansão da oferta de geração e transmissão; (v) limites de

${ }^{3}$ CÂMARA DE COMERCIALIZAÇÃO DE ENERGIA ELÉTRICA. 
transmissão entre submercados; (vi) custo de geração térmica, que traduz o custo de combustível; (vii) disponibilidade de equipamentos de geração e, finalmente, (viii) função do custo de déficit, como sumarizado na Figura 3.6.

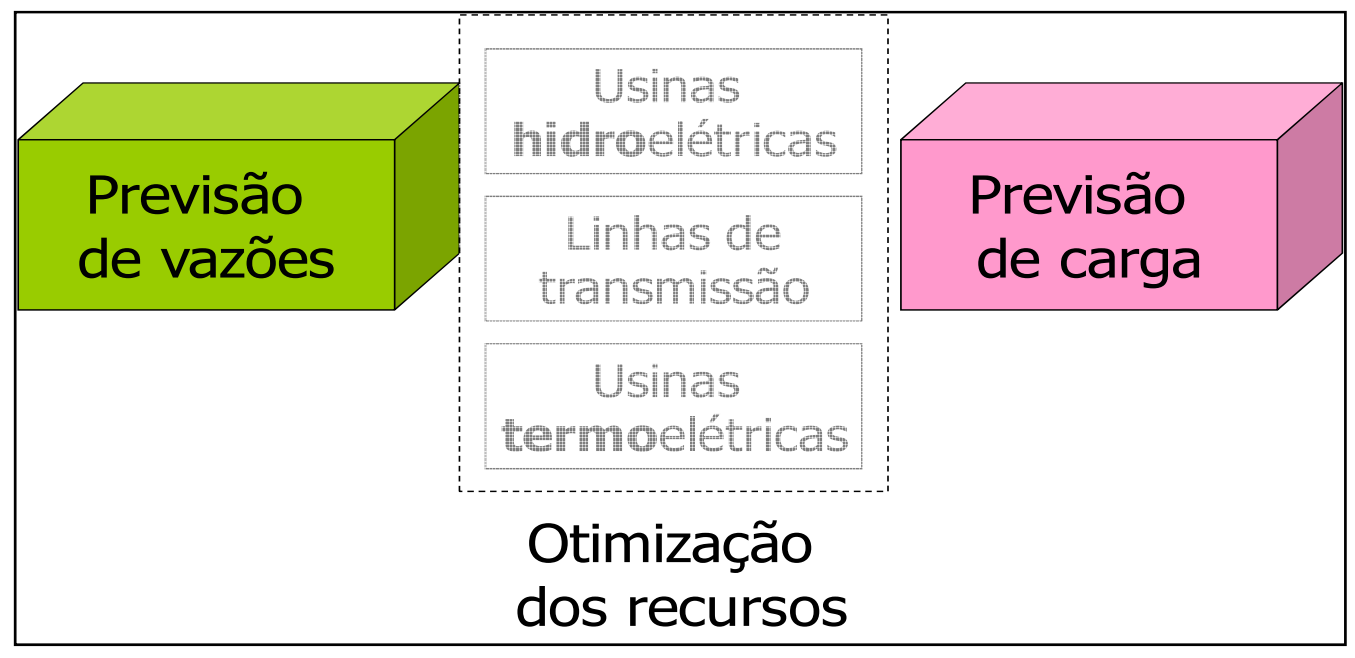

Figura 3.6 - O planejamento da operação eletroenergética ${ }^{4}$

Os modelos computacionais utilizados no cálculo do CMO são o NEWAVE e o DECOMP, ambas as ferramentas são desenvolvidas pelo Centro de Pesquisas de Energia Elétrica - CEPEL.

O NEWAVE é utilizado para otimizar a política de operação no horizonte de médio prazo (5 anos), subdividido em base mensal. Tem como objetivo a definição da Função de Custo Futuro e representa as usinas hidrelétricas de forma agregada, sendo um reservatório equivalente por submercado de energia. O submercado é caracterizado como uma região do sistema elétrico onde não há restrições significativas de transmissão internamente às suas fronteiras, fazendo com que o preço dentro de cada

${ }^{4}$ CÂMARA DE COMERCIALIZAÇÃO DE ENERGIA ELÉTRICA. 
uma dessas regiões seja único. O SIN é constituído por quatro submercados: Sudeste/Centro-Oeste, Sul, Nordeste e Norte.

Já o DECOMP, é o modelo computacional utilizado para horizontes de curto prazo (12 meses) e utiliza a Função de Custo Futuro do NEWAVE como um dado de entrada, para determinação do despacho ótimo por usina que minimiza o custo de operação em um horizonte de programação semanal. 


\section{FORMAÇÃO DE PREÇOS EM MERCADOS DE ENERGIA ELÉTRICA}

Em mercados com participação substancial de geração hidráulica e, especificamente, no caso do Brasil, em que o atendimento à demanda está sujeito à conjuntura hidrológica vigente, os preços de curto prazo não são formados por oferta dos geradores, mas sim como resultado direto do custo marginal de operação do sistema, de maneira intrínseca à sua programação de despacho centralizado.

O preço de curto prazo, batizado de Preço de Liquidação de Diferenças - PLD, é calculado e divulgado pela CCEE e, de fato, é um subproduto dos modelos computacionais utilizados pelo ONS no processo de operação do Sistema Interligado Nacional.

O PLD é determinado para cada submercado constituinte do SIN, Sudeste/CentroOeste, Sul, Norte e Nordeste. Este preço, diferentemente, do custo marginal de operação, não considera as restrições de transmissão internas de cada submercado, ou seja, fazendo com que o preço dentro destes sejam únicos, além de não contemplar as unidades geradoras em fase de testes.

Outro aspecto importante, considerado na formação do PLD, é que este valor reflete as eventuais situações de racionamento de energia, posto que os modelos incorporam a função de custo do déficit ao determinar os preços em cada submercado. Desde 2001, foi introduzida na formação de preço, um item de segurança energética adicional, a chamada Curva de Aversão ao Risco - CAR. 
A "CAR" estipula valores mínimos para os níveis de armazenamento dos reservatórios de cada submercado, sendo que, sob o crivo desses patamares de armazenamento, as usinas termelétricas podem ser solicitadas a operar fora da ordem de mérito econômico, como medida preventiva para manutenção e regularização dos níveis de armazenamento dos reservatórios em condições críticas. Outro fator que afeta a segurança energética do SIN, é a definição dos chamados níveis meta por submercado. Estes valores impõem valores mínimos aceitáveis para os níveis dos reservatórios agrupados por submercado e são definidos pelo ONS, em conjunto com a EPE, sendo disponibilizados para consulta pública depois de aprovados pelo CMSE.

A CCEE faz a contabilização das quantidades de energia contratadas e as quantidades realmente consumidas pelos agentes, comparando esses valores e aferindo as diferenças para efeito de contabilização e liquidação no mercdo de curto prazo. Por conseguinte, as flutuações positivas ou negativas, em torno dos lastros contratuais, são liquidadas ao PLD, ponderando as diferenças de preços entre submercados. A determinação dos preços de liquidação do mercado de curto prazo (PLD's) toma por base os CMO's calculados pelos modelos, limitados por um preço mínimo e um preço máximo, definidos pela ANEEL. A seguir é apresentado um gráfico com o histórico de preços do PLD, divulgados pela CCEE. 


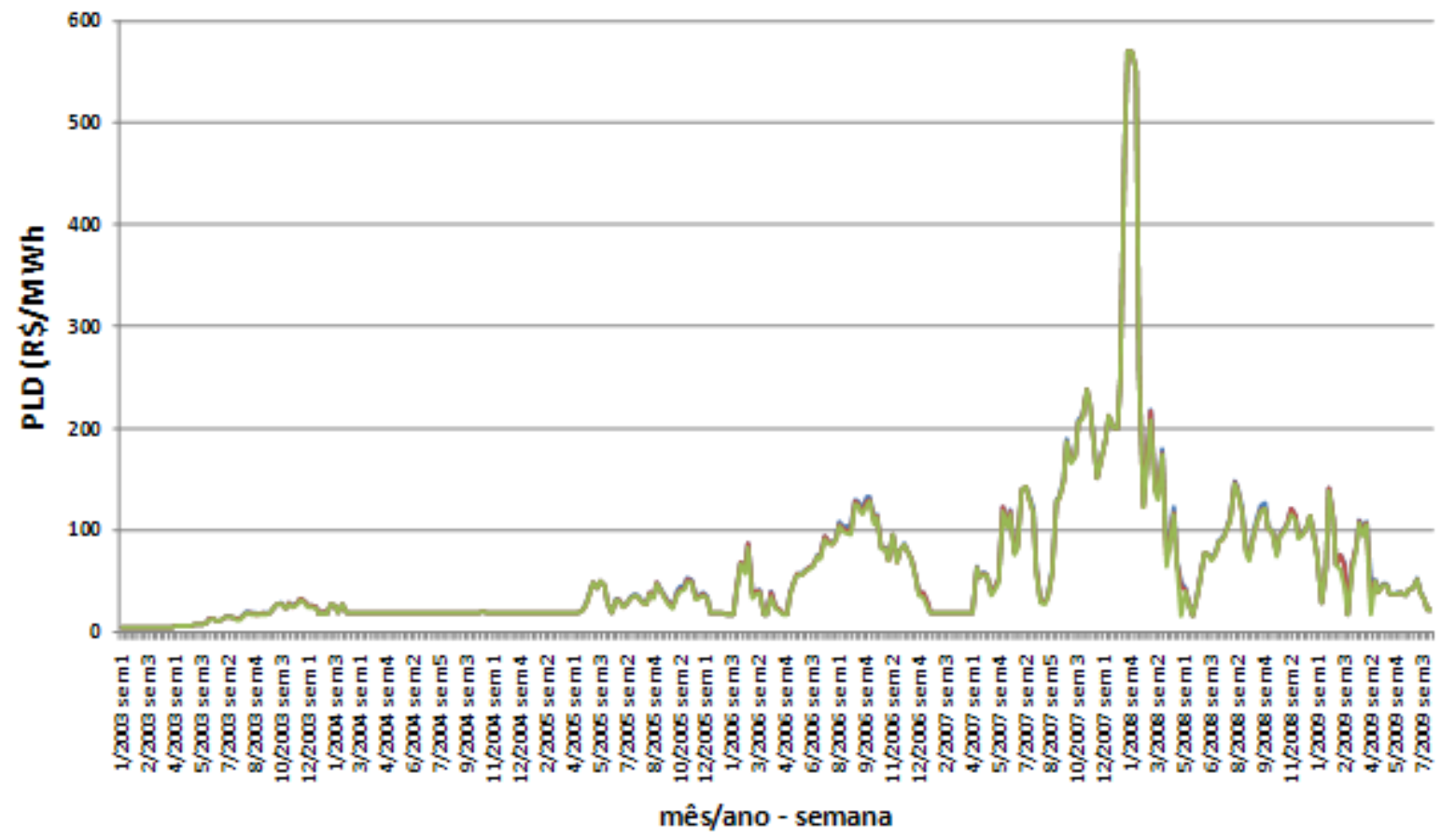

Gráfico 4.1 - Histórico do PLD

\subsection{A VOLATILIDADE DOS PREÇOS DE CURTO PRAZO}

A imprevisibilidade de parâmetros chave ${ }^{5}$ utilizados na programação do despacho das usinas constituintes do SIN e que subsidiam o cálculo dos valores de preço da energia no curto prazo, ou preço spot, introduzem significativa volatilidade, dentro de um determinado intervalo de tempo, ao preço sinalizado para o mercado de curto prazo.

Outro aspecto relevante que influencia na volatilidade dos preços spot é a restrição de transmissão de energia entre submercados, imposta pelas condições operativas das redes do SIN.

\footnotetext{
${ }^{5}$ Como, por exemplo, as variáveis de natureza estocástica, energia natural afluente e regime dos ventos, nesse último caso em virtude da recente incorporação de usinas eólicas ao parque gerador.
} 
Esta característica é conferida pela modelagem empregada na programação da operação do Sistema Interligado Nacional e impõe aos agentes do setor elétrico, principalmente aqueles que participam do Ambiente de Contratação Livre, uma exposição importante que traz associada um risco financeiro, que é função da decisão de contratação do suprimento e se materializa na contabilização no mercado de curto prazo.

\subsection{O MERCADO DE LIVRE CONTRATAÇÃO DE ENERGIA}

Em meados de 2003, as reformulações do setor introduziram o denominado Ambiente de Livre Contratação de Energia - ACL. Neste segmento de mercado, os Consumidores Livres, ao contrário dos Clientes Cativos, podem formalizar a aquisição de energia elétrica para suprimento dos requisitos de seu processo produtivo, através de contratos bilaterais, onde os prazos, os preços e os volumes são livremente negociados com os agentes geradores ou comercializadores.

O consumidor é elegível à livre contratação de energia ao atender os critérios descritos na Tabela 4.1, de acordo com a Lei № 9074, de 08 de julho de 1995, com redação dada pelas Leis N ${ }^{\text {os }} 9648$, de 1998 e 10848, de 2004.

Tabela 4.1 - Condições para poder optar pelo Mercado de Livre Contratação

\begin{tabular}{|l|c|c|}
\hline \multicolumn{1}{|c|}{ Consumidores Livres } & Potência & Tensão \\
\hline Conectados antes de 08/07/1995 & $\geq 3 \mathrm{MW}$ & $\geq 69 \mathrm{kV}$ \\
\hline Conectados após 08/07/1995 & $\geq 3 \mathrm{MW}$ & Qualquer tensão \\
\hline $\begin{array}{l}\text { Quem optar pelo fornecimento através de } \mathrm{PCH}^{\prime} \mathrm{s}, \\
\text { fontes eólicas, biogás e solar }\end{array}$ & $\geq 0.5 \mathrm{MW}$ & Qualquer tensão \\
\hline
\end{tabular}


O Consumidor Livre poderá retornar à condição de consumidor atendido mediante tarifa regulada, garantida a continuidade da prestação dos serviços, desde que informe à concessionária, à permissionária ou à autorizada de distribuição local, com antecedência mínima de 5 (cinco) anos. Este prazo poderá ser reduzido a critério da concessionária, da permissionária ou da autorizada de distribuição local.

O Consumidor Livre Especial denota a unidade consumidora ou conjunto de unidades consumidoras do Grupo A (refere-se à classificação, pela distribuidora de energia, do nível de tensão em que a unidade consumidora é atendida), integrante(s) do mesmo submercado no Sistema Interligado Nacional - SIN, reunidas por comunhão de interesses de fato ou de direito, cuja carga seja maior, ou igual, a $500 \mathrm{~kW}$. As condições para o atendimento ao conjunto de unidades consumidoras, reunidas por comunhão de interesses de fato ou de direito, exigem que as unidades estejam localizadas em áreas contíguas ou possuírem o mesmo Cadastro Nacional de Pessoa Jurídica - CNPJ caso localizadas em áreas não contíguas. Estes clientes atendidos por fontes primárias incentivadas poderão retornar à condição de consumidor atendido por tarifa regulada, mediante aviso à concessionária ou permissionária de distribuição com antecedência de 180 (cento e oitenta) dias em relação à data de início de fornecimento. Este prazo poderá ser reduzido a critério da concessionária ou permissionária de distribuição.

Um dispositivo regulatório em análise para o Consumidor Livre, expresso na Portaria MME №73, de 1ํ de março de 2010, é a cessão de excedentes contratuais. A proposta desta Portaria foi disponibilizada em 02.03.2010, para Consulta Pública e visa estabelecer as diretrizes para regulamentar a cessão de excedentes contratuais de 
energia elétrica por consumidores livre e especial, definidos pelo Decreto 5.163 de 30.07.2004 e pela Resolução ANEEL 247 de 21.12.2006. Mesmo com prazo de contribuição esgotado, o MME ainda não providenciou a consolidação da Proposta colocada em Consulta Pública, incorporando as contribuições dos Agentes.

A citada portaria define que os montantes de energia a serem descontratados pelos consumidores, quando de seu interesse, devem seguir limites pré-definidos dos contratos celebrados e registrados na CCEE:

- Cessão Integral: Neste caso, não há restrição envolvendo a duração do contrato e seus percentuais. Uma vez que se trata de uma energia que ainda não foi incorporada ao parque de geração e, representa, portanto uma energia "nova" para o sistema elétrico, ou seja, o empreendimento que proporciona a garantia física e constitui o respectivo lastro para a venda da energia, ainda não está em operação. Neste caso, temos:

- Contrato com até cinco anos contados da data do ato de outorga de concessão para a implantação do empreendimento que proporciona a garantia física que constitui o respectivo lastro para venda;

- Contrato com até três anos contados da data do ato de outorga de autorização para implantação do empreendimento que proporciona a garantia física que constitui o respectivo lastro para venda. 
- Cessão Limitada a percentuais: Já nesta situação, o repasse dos contratos, refere-se a uma energia já participante do parque gerador e, desta maneira, é tratada como uma energia "velha", ou seja, o empreendimento que proporciona a garantia física e constitui o respectivo lastro para a venda da energia, já está em operação. Para esta condição, foi estabelecido que:

- Até $10 \%$ da energia contratada para contratos de menos de 2 anos;

- Até $20 \%$ para contratos entre 2 e 5 anos;

- Até $50 \%$ para contratos de 5 a 10 anos;

- Integral para contratos que durem mais de 10 anos.

A opção de pertencer ao ACL impõe ao consumidor a identificação e a utilização adequada de instrumentos para o gerenciamento eficiente dos riscos, de lastro contratual, de preços, de tarifas pelo uso dos sistemas de transmissão e distribuição e, finalmente, de limites de descontratação para flexibilização dos contratos, enfrentados na aquisição de eletricidade neste ambiente de contratação. 


\section{PREMISSAS, CONCEITOS E METODOLOGIA PARA 0 DESENVOLVIMENTO DA PESQUISA}

\subsection{CONSIDERAÇÕES GERAIS}

Os acordos, ou contratos, são os dispositivos de hedge no âmbito do ACL contra as variações de preços no curto prazo, pois proporcionam, para as partes envolvidas na negociação, previsibilidade e estabilidade, de receita no caso do produtor e, de custo, no caso do consumidor. Os contratos, nesse contexto, em geral protegem os agentes envolvidos, mas podem implicar em prejuízo financeiro, ou pelo menos em uma redução das oportunidades de ganho, em algumas situações. Este fato torna nebulosa a definição da melhor estratégia de contratação, impondo decisões criteriosas e muito bem avaliadas em todos os seus prós e contras.

O presente trabalho analisa os custos de aquisição de energia elétrica no Ambiente de Contratação Livre. Inicialmente, formulam-se os conceitos e se desenvolve os procedimentos para formatar uma metodologia de precificação de contratos de energia elétrica e, também, de avaliação dos riscos associados às modalidades contratuais de aquisição deste insumo.

A análise contempla distintos cenários macro-econômicos, que condicionam as condições de balanço de oferta e demanda no Sistema Interligado Nacional, com rebatimento na fixação dos preços para contratação tanto de curto (entre um e dois anos de vigência), quanto de longo prazo (entre três e cinco anos de vigência). 
Na seqüência, o texto aborda os resultados emulados para cenários alternativos de oferta de energia elétrica, caracterizados por nuances bastante distintas e, em seguida, compara a eficácia da contratação de longo prazo para mitigar os riscos de exposição financeira aos preços praticados no Mercado de Curto Prazo, perfazendo ainda, análises criteriosas com foco na cessão de excedentes contratuais pelos agentes com prerrogativas de Consumidor Livre.

\subsection{RESUMO DA METODOLOGIA}

A metodologia de precificação e avaliação dos riscos dos contratos firmados no Mercado Livre aqui descrita, baseia-se nos valores do custo marginal de operação, CMO, obtidos a partir de simulação do software NEWAVE .

Este programa, desenvolvido pelo CEPEL - Centro de Pesquisas de Energia Elétrica, gerencia o despacho hidrotérmico das usinas conectadas ao Sistema Interligado Nacional. Para a sua operação são contempladas as informações de séries hidrológicas históricas, a composição do Parque Gerador Brasileiro e a projeção de demanda por energia no País para um horizonte temporal de médio prazo.

\subsection{PREMISSAS}

Para efeito deste trabalho, considera-se a opção do consumidor de pertencer ao Mercado Livre já tomada, ou seja, pressupõe-se que o agente já decidiu por adquirir energia no ACL. 
O horizonte de análise para simular as diversas modalidades contratuais é igual a 10 anos. Isto porque é coincidente com o prazo temporal de estudo das projeções de preços, CMO, extraídas do NEWAVE.

Para o citado horizonte de tempo, adotou-se a hipótese de moeda constante, de modo que os contratos não sofreram qualquer reajuste dentro dos seus respectivos prazos de validade.

Outro aspecto considerado é que a estratégia de contratação será baseada em uma única escolha no período analisado. Ou seja, para um prazo contratual escolhido, o horizonte temporal é coberto por vários contratos de mesmo prazo de vigência até o final do período simulado. Não se considera, portanto, a alternância de estratégias para o período de análise comparativa adotado (10 anos), de acordo com a Figura 5.1. Esta premissa é calcada no objetivo de decidir sobre a melhor estratégia de contratação comparando o comportamento médio dos preços nos contratos curtos em contraposição aos contratos de longa duração dentro do horizonte de análise de 10 anos. Estes contratos lastreiam a totalidade da carga exigida pelo consumidor no momento de sua efetivação.

Além disso, no estudo elimina-se a influência das condições de partida da simulação (nível de armazenamento dos reservatórios e afluências anteriores). O intuito desta imposição é poder aferir o comportamento médio dos preços nas diversas modalidades contratuais para um horizonte de longo prazo e, dessa maneira, não fixar o processo decisório em uma condição estática específica do Sistema Interligado Nacional no início do período emulado. 
Essa hipótese é semelhante àquela utilizada para o cálculo de garantia física dos empreendimentos de geração de energia elétrica, na qual se adota, como configuração de partida, um estado inicial após inclusão de 10 anos no horizonte de simulação, antecedendo o período de estudo.

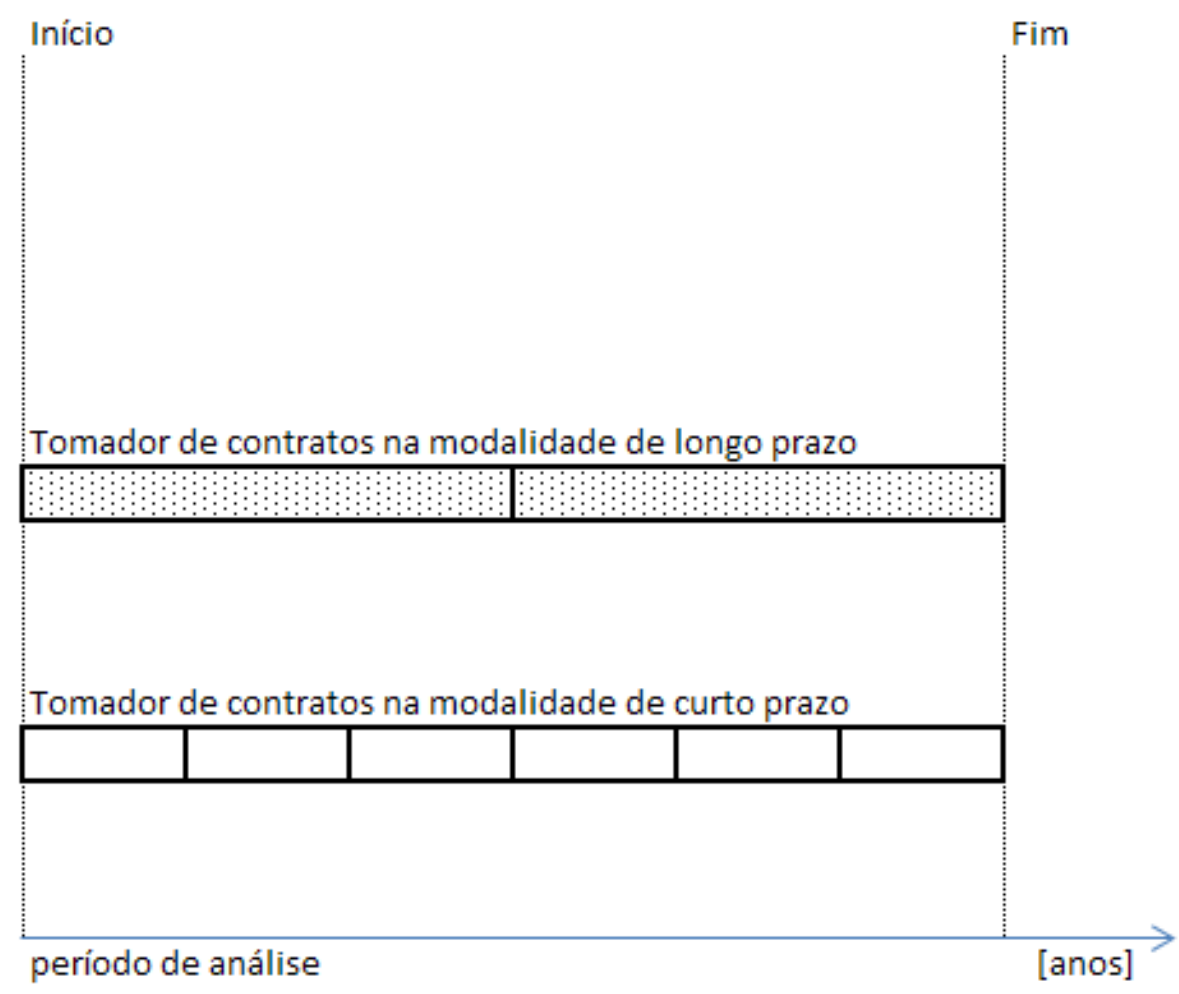

Figura 5.1 - Estratégia de contratação baseada em uma única escolha no período de análise

Em uma situação real, a metodologia poderia ser aplicada a partir de uma condição de partida específica, comparando os resultados vinculados a essa condição inicial.

\subsection{PRECIFICAÇÃO DOS CONTRATOS}

A precificação dos contratos bilaterais no Mercado Livre (ACL), como conceito básico, responde à conjunção de duas expectativas, quais sejam, o comportamento dos preços no mercado de curto prazo (PLD) e o comportamento esperado dos preços para 
expandir a oferta do parque de geração, Preço da Energia Nova (PEN), este último obtido das ofertas vencedoras dos leilões realizados para atendimento da totalidade do mercado referenciado ao Ambiente de Contratação Regulado (ACR), conforme a descrição feita a seguir:

"As concessionárias, as permissionárias e as autorizadas de serviço público de Distribuição de energia elétrica do Sistema Interligado Nacional (SIN), por meio de licitação na modalidade de leilões, devem garantir o atendimento à totalidade de seu mercado no Ambiente de Contratação Regulada (ACR), de acordo com o estabelecido pelo artigo 11 do Decreto $n^{\circ}$ 5.163/2004 e artigo $2^{\circ}$ da Lei $n^{\circ}$ 10.848/2004.

O critério de menor tarifa (inciso VII, do art. 20, do Decreto $n^{\circ}$ 5.163/2004) é utilizado para definir os vencedores de um leilão, ou seja, os vencedores do leilão serão aqueles que ofertarem energia elétrica pelo menor preço por Mega-Watt hora para atendimento da demanda prevista pelas Distribuidoras. Os Contratos de Comercialização de Energia Elétrica em Ambiente Regulado (CCEAR), serão, então, celebrados entre os vencedores e as Distribuidoras que declararam necessidade de compra para o ano de início de suprimento da energia contratada no leilão.

Considerando-se "A" como o ano previsto para o início do suprimento de energia elétrica adquirida pelos Agentes de Distribuição nos leilões de energia, o cronograma para a realização dos leilões é o seguinte:

* No quinto ano anterior ao ano "A" (chamado ano "A" - 5), é realizado o leilão para compra de energia de novos empreendimentos de Geração;

* No terceiro ano anterior ao ano "A" (chamado ano "A" - 3), é realizado o leilão para aquisição de energia de novos empreendimentos de Geração;

* No ano anterior ao ano "A" (chamado ano " $A$ " - 1), é realizado o leilão para aquisição de energia de empreendimentos de Geração existentes. 
Além disso, poderão ser promovidos Leilões de Ajuste, previstos no artigo 26 do Decreto no 5.163, de 30/07/2004, tendo por objetivo complementar a carga de energia necessária ao atendimento do mercado consumidor das concessionárias de distribuição, até o limite de 1\% dessa carga (CCEE, 2011)."

Para tanto, os ingredientes básicos a serem contemplados na busca de regras para aproximar o mecanismo de mercado que conduz à formação dos preços dos contratos são:

* Projeção do PLD

* Duração do Contrato

* Prazo para início de entrega da energia (delay de entrega)

* Preço da Oferta Estrutural de Energia Futura (Preço da Energia Nova)

A idéia básica seria estabelecer uma combinação desses fatores, tendo-se definido pelo procedimento empírico apresentado a seguir, para estabelecimento de preços representativos de contratos de um ano, com entrega da energia em momentos distintos, que seriam o ano inicial e seguintes, de modo a cobrir o período de duração dos contratos (a notação $1^{\circ}$ ano $/ 2^{\circ}$ ano, etc, deno ta contrato de duração de um ano com entrega a partir do ano indicado).

* 1 Ano : Projeção do preço de curto prazo (PLD) + uma porcentagem de ágio praticado na comercialização da energia no curto prazo.

* 2 Ano : 90 \% preço de curto prazo (PLD) e $10 \%$ custo marginal de expansão, CME (A-3 / Existente / Ajuste / Geração Distribuída). 
* 3ำ Ano : $20 \%$ preço de curto prazo (PLD) e $80 \%$ custo marginal de expansão, CME (A-3 / Existente / Ajuste / Geração Distribuída) .

* 4ํㅡㄹ : custo marginal de expansão, $\mathrm{CME}_{\mathrm{A}-5} / \mathrm{CME}_{\mathrm{A}-3}$.

* 5o Ano para frente : custo marginal de expansão, $\mathrm{CME}_{\mathrm{A}-5}$.

O diagrama da Figura 5.2 resume a aplicação dos drivers para a formação dos preços contratuais.

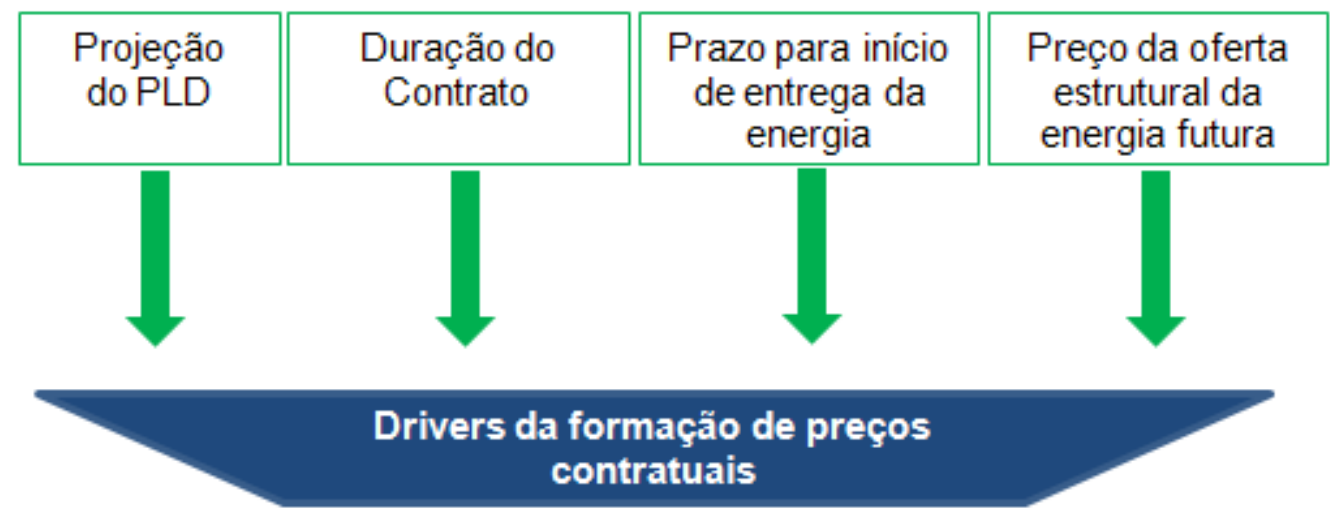

\section{Regras para a formação de preços nas diversas} modalidades contratuais

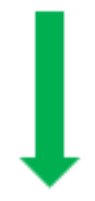

1 Ano Vigência

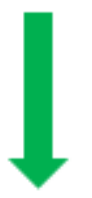

2 Anos Vigência

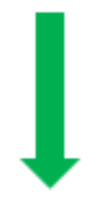

3 Anos Vigência

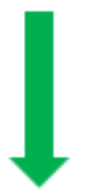

4 Anos Vigência
5 Anos Vigência

Figura 5.2 - Ingredientes da formação de preços contratuais 
Com o intuito de emular a formação dos preços contratuais no Ambiente de Contratação Livre foram incorporadas as seguintes hipóteses para balizar 0 comportamento dos preços neste mercado:

- Os contratos de curto prazo, com vigência de um ano, estão fortemente atrelados às condições de oferta de energia no momento da renovação contratual e, portanto, estes acordos são modelados com a influência dos preços de curto prazo (PLD) somente, ou seja, os preços de liquidação de diferenças contratuais no Mercado de Curto Prazo, agregando-se o ágio usual praticado no mercado de curto prazo.

- Contratos com duração de dois anos também se encontram fortemente influenciados pela conjuntura e são precificados considerando uma ponderação entre preços spot (PLD) e preços de aquisição de energia para contratos de longo prazo, conforme se explicará posteriormente. Na citada ponderação, os preços de energia que formarão o contrato serão os preços do mercado de curto prazo com ponderação 100 \% para o primeiro ano, assumindo ponderação ainda bastante alta para o segundo ano (por exemplo, 90\%). O complemento de energia, que se supõe adquirir e que influencia a formação do preço de contrato, é representado por um mix de ofertas de maior prazo de contratação, como por exemplo, Leilões de Energia Existente (A-1); Leilões de Ajuste e Geração Distribuída, que são opções coerentes para entrega em dois anos.

- Por sua vez, os contratos de longo prazo, aqui definidos com vigência entre três e cinco anos, também possuem parcelas ponderadas pela hidrologia vigente, 
preços de curto prazo (PLD), mas são, predominantemente, influenciados pelo Preço da Energia Nova (PEN), ou seja, o valor do custo unitário ( $\$$ \$MWh) para os novos empreendimentos de energia que serão incorporados ao parque de geração do País.

O conceito utilizado aqui é o de "valor justo da energia", que se baseia na determinação de um preço de contrato que represente o equivalente econômico de diversos preços anuais de aquisição de energia. Nesse contexto, cada um desses preços representa, por sua vez, o preço de mercado para adquirir o bloco correspondente de energia, como um mix de diversas opções viáveis, assumindo-se a entrega exatamente no ano do horizonte de contrato que se esteja considerando.

Assim, por exemplo, o preço para um contrato de três anos será constituído por um preço justo da energia que considere (i) um valor representativo do preço para contratos de um ano e entrega imediata, (ii) um valor representativo do preço de aquisição de um bloco de energia com um ano de duração e entrega um ano depois do início da contagem do tempo de contrato. Finalmente, incorpora-se (iii) um valor para representar a aquisição de um bloco de energia com um ano de duração e entrega a dois anos do início da contagem do tempo de contrato. Seguindo essa lógica, são apresentadas as formulações para definições dos preços contratuais.

\subsubsection{Contratos com vigência de um ano}

Para cada ano de operação do sistema submetido a uma possível série hidrológica de vazões afluentes (série proveniente do Histórico ou Sintética), caracterizado pelas respectivas séries projetadas dos custos marginais de operação do Sistema Interligado 
Nacional, o preço spot de cada mês é trazido a valor presente para o mês de janeiro do ano de renovação contratual.

O valor do contrato é então calculado, pela média dos valores presentes mensais, de acordo com (1).

$$
C_{1}=\frac{\sum_{m=1}^{12} \frac{\text { spotMed }_{m}}{(1+i)^{m-1}}}{12}
$$

Onde:

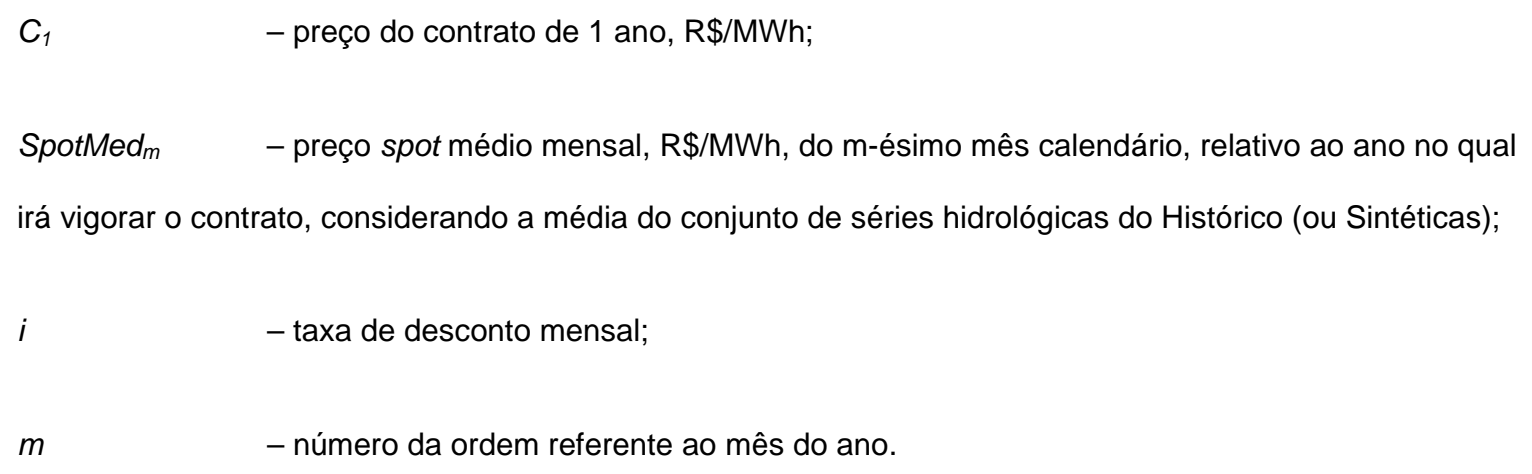

A metodologia para o cálculo do preço dos contratos com um ano de duração é apresentada na Figura 5.3 a seguir, para a qual se aplica a seguinte notação:

[ 1 ] - Período de análise - corresponde ao horizonte de tempo a ser considerado na simulação da contratação de energia;

[ II ] - Duração do contrato - denota o tempo de vigência da modalidade contratual;

[ III ] - Séries de preços - indicam as séries de preços extraídas do software NEWAVE;

[ IV ] - Taxa de atualização do capital - refere-se à taxa de juros considerada para a atualização monetária;

[ V ] - Cálculo pela equação (1) - etapa que indica a aplicação da equação (1) para cada ano dentro de cada uma das séries de preços do NEWAVE; 
[VI] - Nesta etapa são formados os preços dos contratos para cada ano dentro de cada uma das séries de preços;

[ VII ] - Preço Médio dos contratos de um ano - finalmente, são disponibilizados os preços médios dos contratos de um ano no horizonte de simulação. De modo que, cada contrato de um ano de duração, é a média aritmética, no horizonte de tempo correspondente, entre todos os contratos de um ano de vigência nas diversas séries de preços.

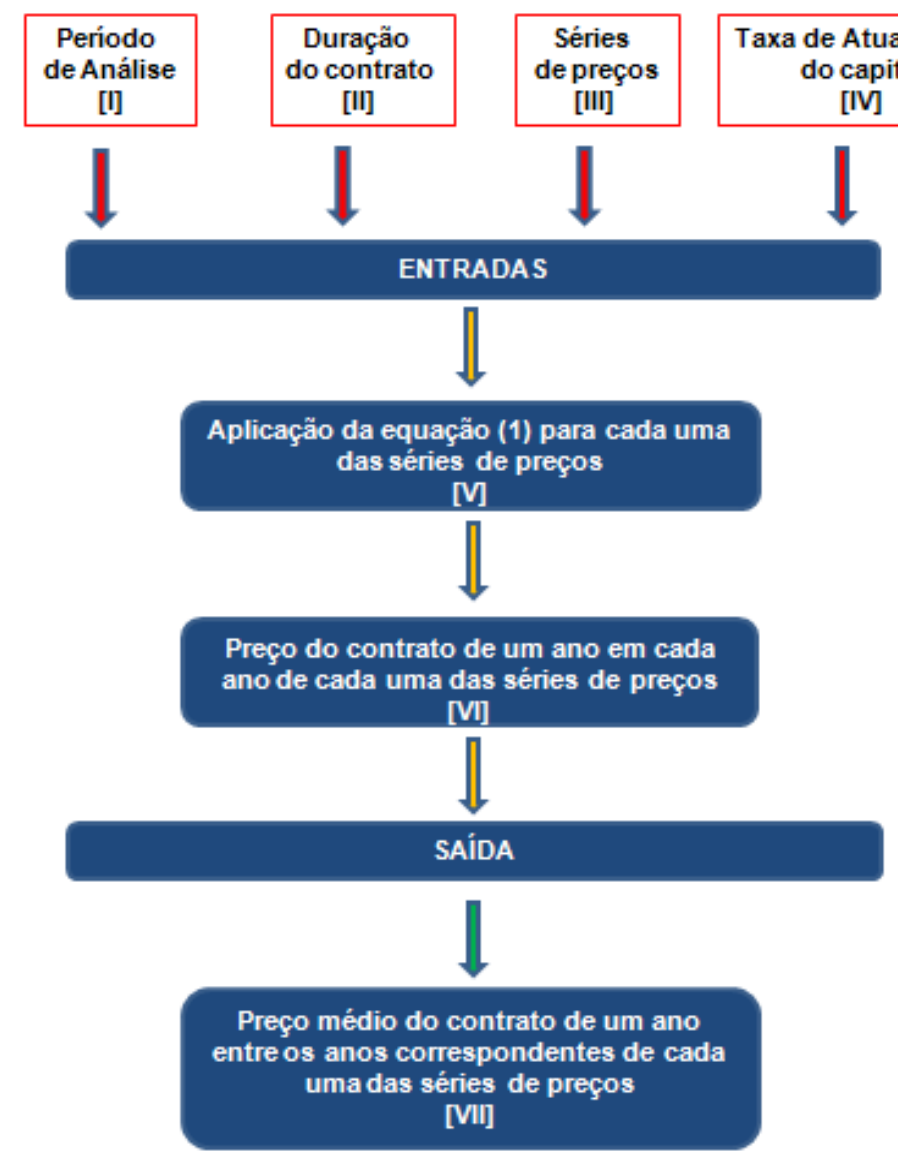

Figura 5.3 - Fluxograma de formação do preço dos contratos com 1 ano de duração

Para exemplificar a metodologia empregada, sugere-se que no instante de início da contratação ( $t_{0}$ ), avalie-se a expectativa dos preços da energia para o horizonte temporal de vigência do contrato, utilizando os valores encontrados para compor os preços dos contratos com duração de um ano, como ilustrado no Gráfico 5.1. 
Aplicando essa metodologia a cada uma das séries hidrológicas disponibilizadas pela simulação do modelo NEWAVE foi possível compor os preços contratuais para o período de análise de dez anos. Ao final, computou-se a média aritmética entre todas as séries utilizadas resultando nos preços médios de cada um dos contratos de um ano dentro do horizonte de simulação total de dez anos.

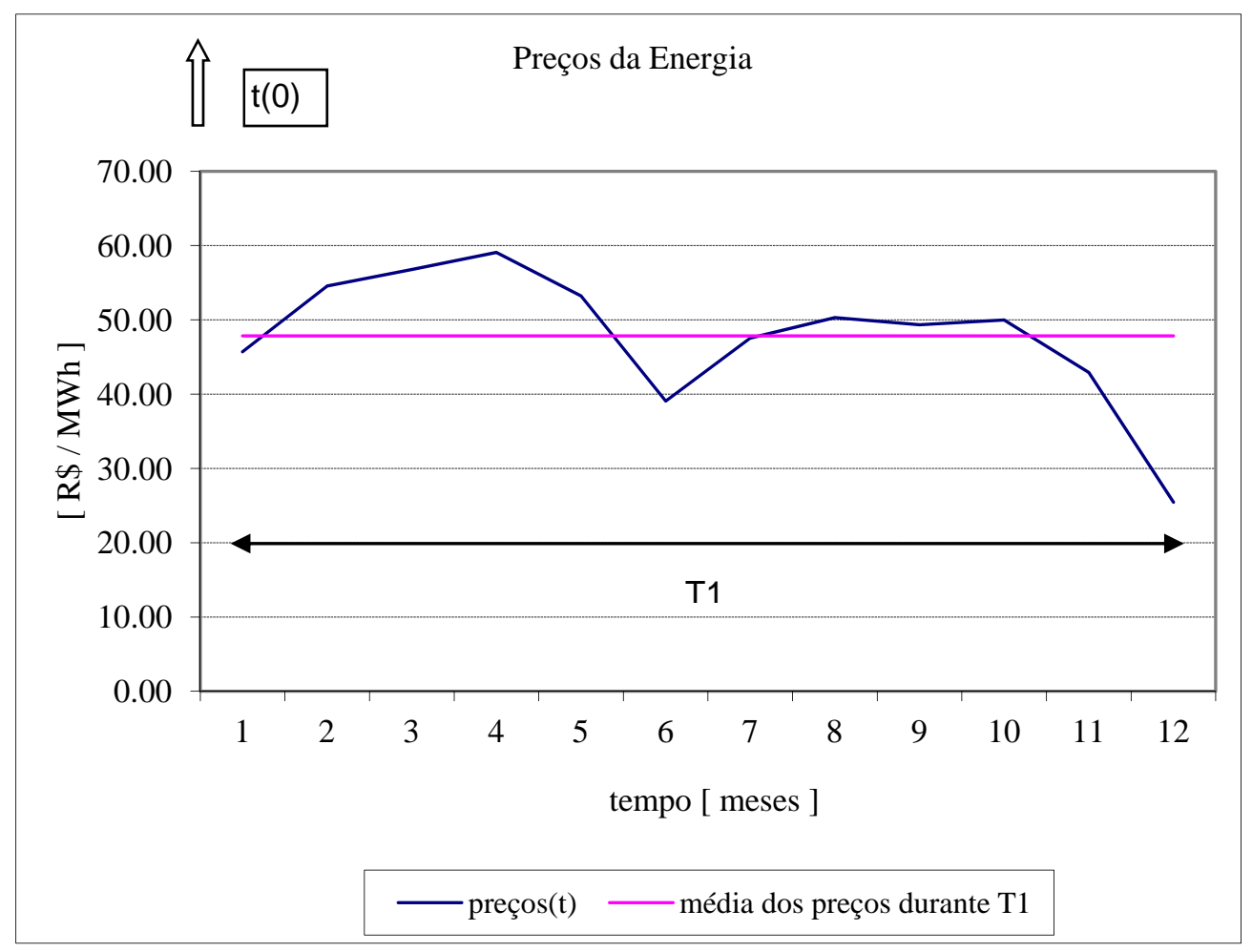

Gráfico 5.1 - Exemplificação do procedimento de formação do preço dos contratos com vigência de um ano

\subsubsection{Contratos com vigência de dois anos}

Para os contratos com duração de dois anos, o método de formação de preços é semelhante ao desenvolvido anteriormente. 
No entanto, propõe-se uma etapa adicional para emular a incerteza no comportamento da hidrologia sobre o segundo ano do horizonte temporal de vigência do contrato.

O processo consiste na escolha de valores de custo marginal de operação para o segundo ano à frente do instante de renovação contratual, de tal forma que a partir do preço de contrato calculado para o primeiro ano a frente do instante de recontratação, define-se uma faixa de valores aceitáveis para o segundo ano em que o contrato vigorará, de acordo com (2), representando, em outras palavras, de uma forma bastante aproximada, o reflexo da faixa de abertura das projeções de vazão, devido ao aumento da incerteza, no segundo ano do horizonte de análise.

$$
(1-f) * V d o 1^{\circ} \text { ano } \leq V d_{k} 2^{\circ} \text { ano } \leq V d o 1^{\circ} \text { ano } *(1+f)
$$

Onde:

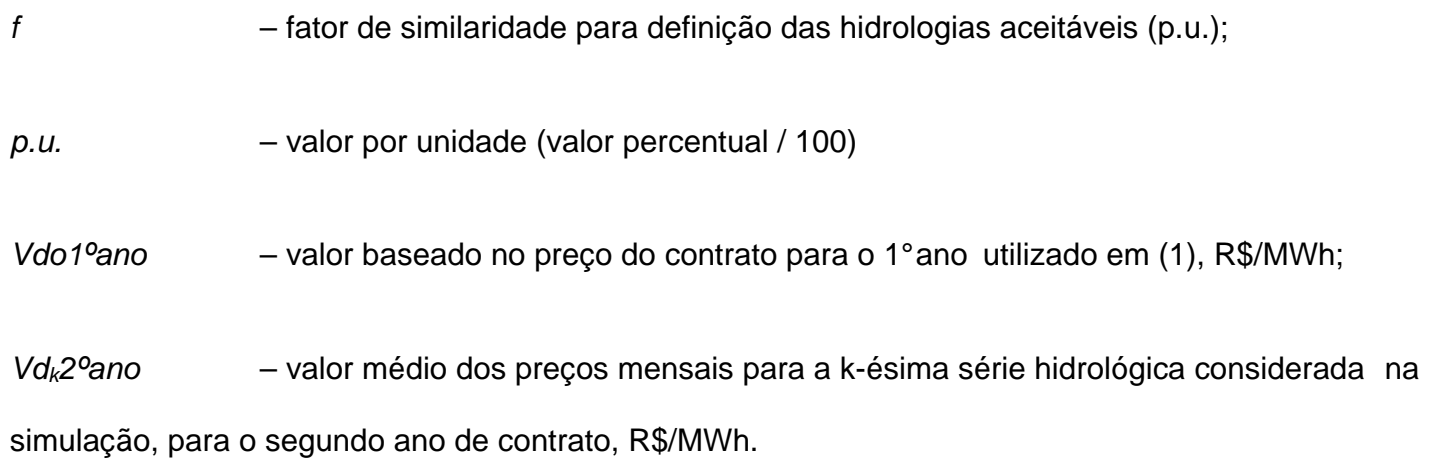

Na seqüência, definidas as séries "similares" àquelas que caracterizam os preços do $2^{\circ}$ ano de contrato, calcula-se o preço spot médio do $2^{\circ}$ ano do contrato, conforme segue em (3). 


$$
P_{2 s}=\frac{\sum_{k=L m}^{L M}\left\{\frac{\sum_{m=1}^{12}\left[\frac{S^{S p o t} t_{m, k}}{(1+i)^{m-1}}\right]}{12}\right\}}{(L M-L m)}
$$

Onde:

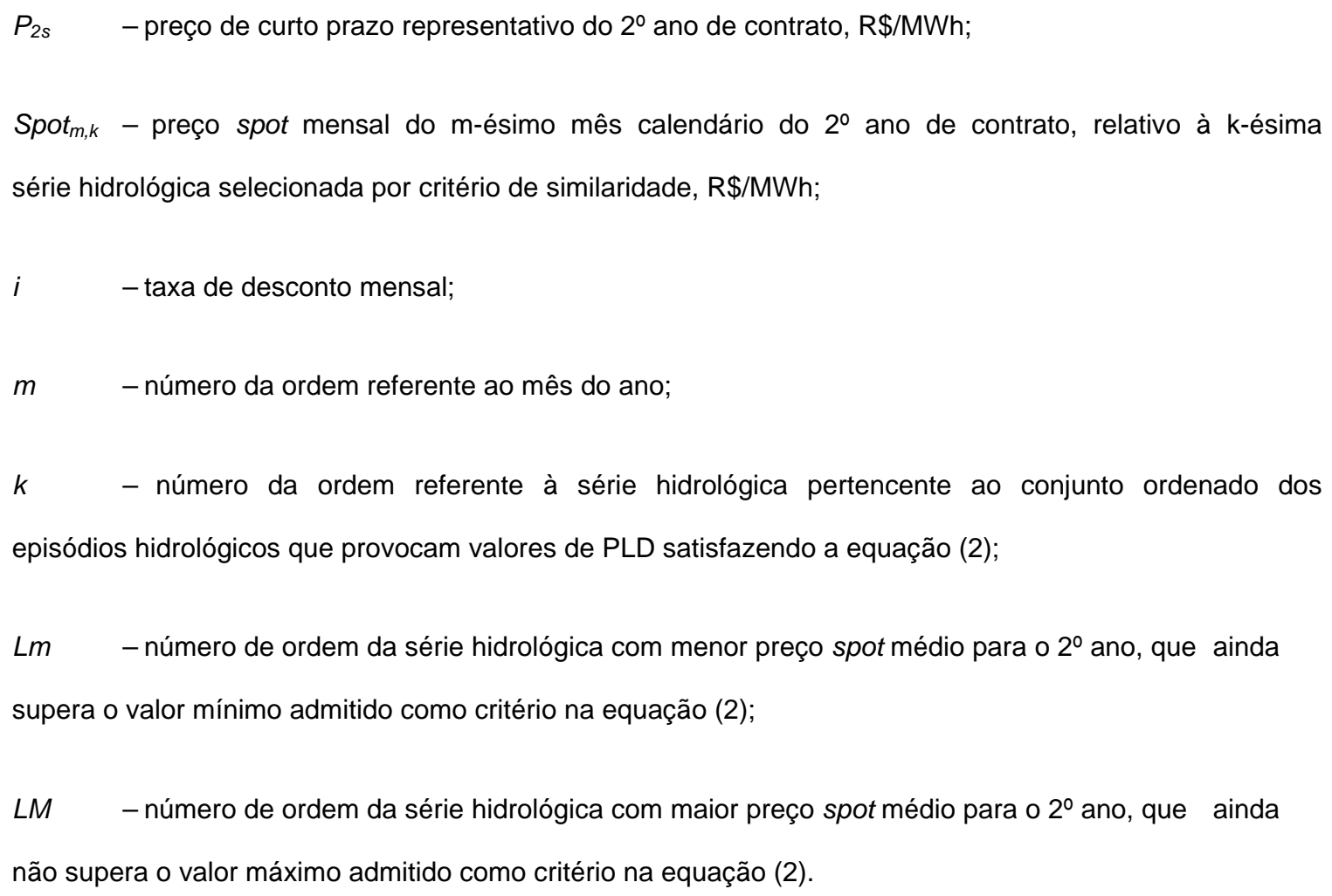

Dessa maneira, é possível determinar, a partir de séries de valores de preços spot (PLD), o valor médio do preço de curto prazo para o segundo ano a frente do instante de recontratação.

Como critério de consistência, considera-se portanto, para compor a média, um conjunto mais restrito de séries, extraídas da distribuição original, representando uma distribuição de probabilidades condicionada para as afluências do $2^{\circ}$ ano do horizonte, 
de tal forma que as afluências de um determinado ano estão correlacionadas com as do ano anterior. Este processo é resumido na Figura 5.4.

Uma vez definido o valor representativo do preço de curto prazo para o segundo ano de cobertura do contrato, determina-se o valor representativo do preço de longo prazo, ponderando as opções de oferta que oferecem possibilidade de contratação de longa duração e, ao mesmo tempo, permitem entrega de energia no $2^{\circ}$ ano do horizonte. Sendo $P_{2 L P}$ esse valor, a equação (4) que se segue permite calcular o preço ponderado para representar o $2^{\circ}$ ano de contratação.

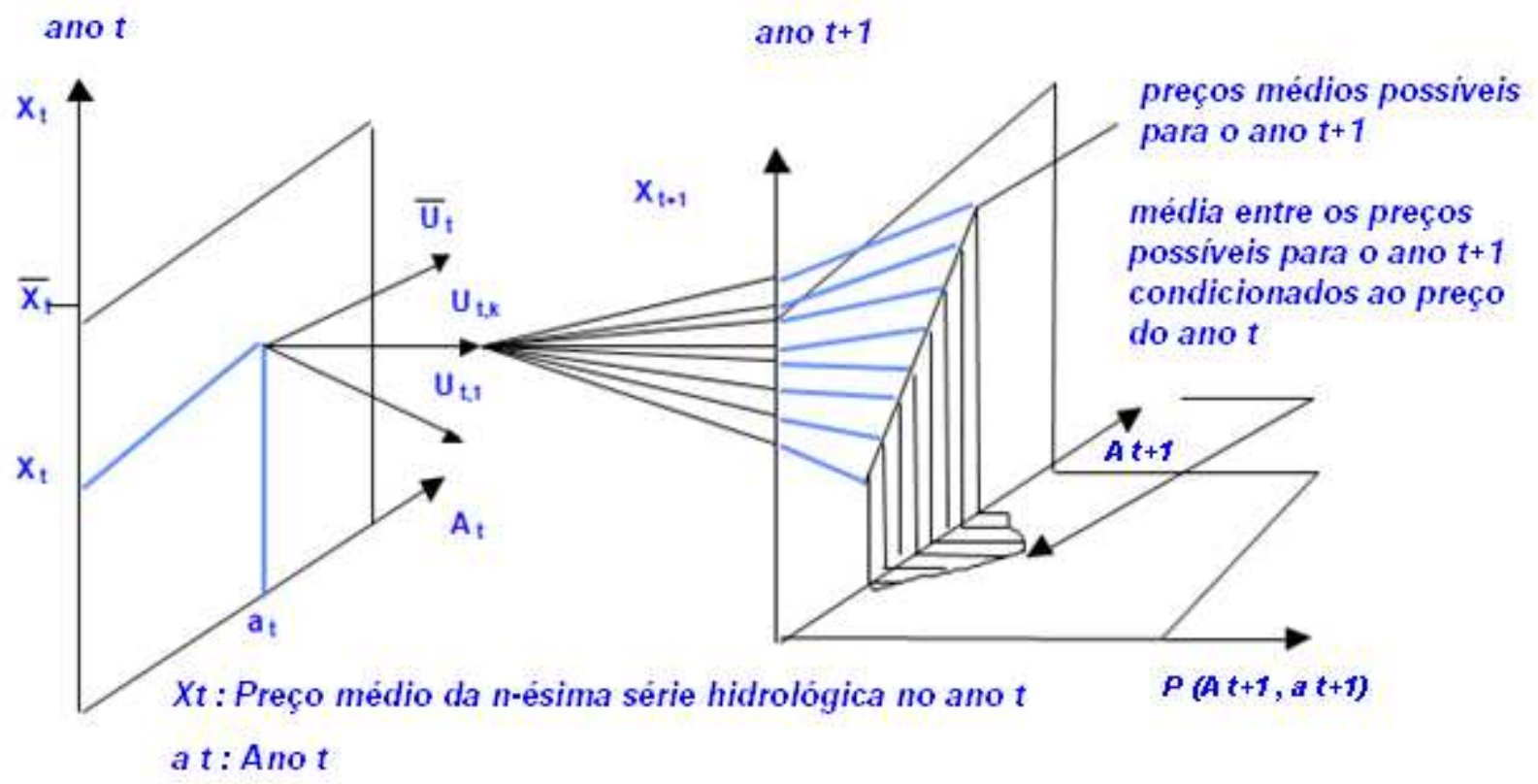

Figura 5.4 - Representação da escolha de hidrologias similares

$$
P_{2}=\left[x * P_{2 s}+(1-x) P_{2 L P}\right]
$$

Onde:

$P_{2} \quad$ - preço que irá vigorar durante o segundo ano de cobertura do contrato, $\mathrm{R} \$ / \mathrm{MWh}$; 
$x \quad$ - valor por unidade (valor percentual / 100) de tal forma a ponderar os preços que formarão o segundo ano de cobertura do contrato;

$P_{2 s} \quad$ - preço de curto prazo representativo do $2^{\circ}$ ano de contrato, $\mathrm{R} \$ / \mathrm{MWh}$, calculado pela equação (3);

$P_{2 L P} \quad$ - preço de longo prazo representativo do $2^{\circ}$ ano de contrato, $\mathrm{R} \$ / \mathrm{MWh}$, sendo este, um mix de ofertas com maior prazo de contratação e coerentes com entrega em dois anos como: Leilões de Energia Existente (A-1), Leilões de Ajuste e Geração Distribuída.

Com base neste valor, aplica-se a equação (5) para se obter o preço do contrato com dois anos de duração.

$$
C_{n}=\frac{\sum_{k=1}^{n}\left(\frac{P_{k}}{(1+i)^{k-1}}\right)}{\sum_{k=1}^{n}(1+i)^{k-1}}
$$

Onde:

$C_{n} \quad-$ preço do contrato de $\mathrm{n}$ anos, $\mathrm{R} \$ / \mathrm{MWh}$;

$P_{k} \quad-$ preço médio do ano a frente do instante de recontratação, $\mathrm{R} \$ / \mathrm{MWh}$, calculado com as equações (1) e (4).

O fluxograma para a formação dos preços contratuais com dois anos de duração é apresentado na Figura 5.5 a seguir, para a qual se aplica a seguinte notação:

[ l ] - Período de análise - corresponde ao horizonte de tempo a ser considerado na simulação da contratação de energia;

[ II ] - Duração do contrato - denota o tempo de vigência da modalidade contratual;

[ III ] - Séries de preços - indicam as séries de preços extraídas do software NEWAVE;

[ IV ] - Taxa de atualização do capital - refere-se à taxa de juros considerada para a atualização monetária; 
[ V ] - Fator de similaridade - fator de similaridade para definição das hidrologias aceitáveis (p.u.);

[ VI ] - Preço de expansão da oferta de energia $\operatorname{CME}(\mathrm{A})$ - refere-se ao custo marginal de expansão com prazo de entrega de energia compatível com o horizonte de dois anos. Este valor é o preço definido nos Leilões de energia: A-3, Existente, Ajuste ou Geração Distribuída;

[ VII ] - Pesos para formar o preço do $2^{\circ}$ ano do contrato - estes valores são utilizados para ponderar o $2^{\circ}$ ano de vigência do contrato entre o preço de curto prazo e também pelo custo marginal de expansão definido em [ VI ];

[ VIII ] - Cálculo do preço anual - etapa que indica a aplicação da equação (1) para o cálculo do preço anual dentro de cada uma das séries de preços do NEWAVE;

[ IX ] - Seleção das séries de preços similares - através da aplicação da equação (2);

[X ] - Definição do preço do $1^{\circ}$ ano de vigência do contrato - nesta etapa é formado o preço referente à parcela do $1^{\circ}$ ano que irá compor o valor do contrato de dois anos;

[XI ] - Definição do preço do $2^{\circ}$ ano de vigência do contrato - nesta etapa é formado o preço referente à parcela do $2^{\circ}$ ano que irá compor o valor do contrato de dois anos;

[ XII ] - Ponderação para ajustar o preço do $2^{\circ}$ ano de vigência do contrato - o preço referente à parcela do $2^{\circ}$ ano é formado pelo mix de preço spot associado ao $2^{\circ}$ ano, mesclado com o valor de custo marginal de expansão definido na etapa [ VI ];

[ XIII ] - Cálculo do preço do contrato com 2 anos de vigência - forma-se o preço contratual de dois anos pela aplicação da equação (5), que contempla as parcelas calculadas nas etapas [ X ] e [ XII ];

[XIV] - Preço Médio dos contratos de dois anos de duração - finalmente, são disponibilizados os preços médios dos contratos de dois anos para o horizonte de simulação. De modo que, cada contrato de dois anos de duração, é a média aritmética, no horizonte de tempo correspondente, entre todos os contratos de dois anos de vigência nas diversas séries de preços consideradas. 


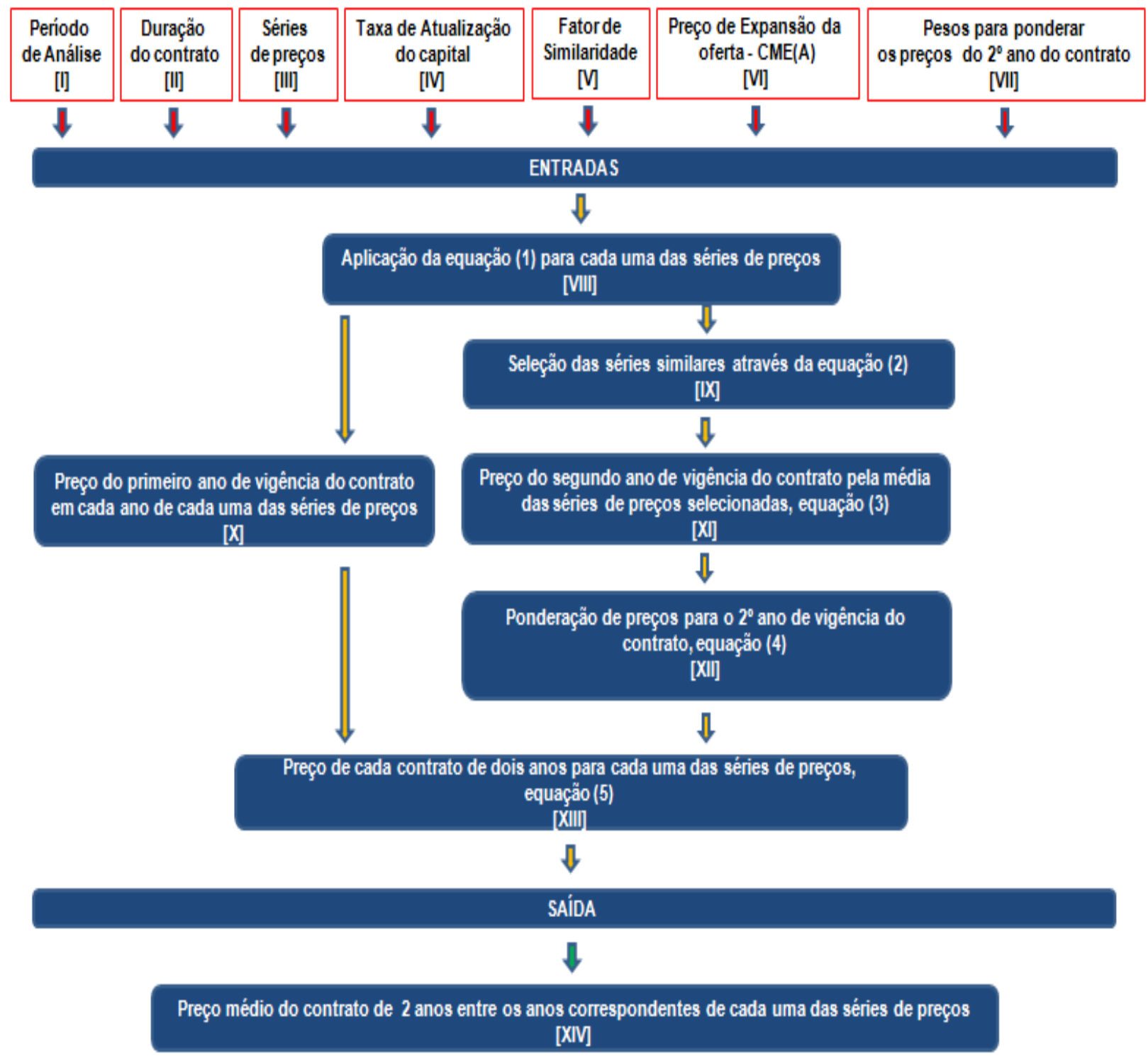

Figura 5.5 - Fluxograma de formação do preço dos contratos com 2 anos de duração

Na sequência é exemplificada a metodologia empregada na constituição dos preços contratuais com vigência de dois anos, onde no instante de início da contratação ( $t_{0}$ ), monitora-se a expectativa dos preços da energia para os próximos dois anos, utilizando 
os valores encontrados, mais o custo marginal de expansão (CME), para compor os preços dos contratos com duração de dois anos, de acordo com o Gráfico 5.2.

É importante enfatizar uma das principais premissas assumidas nesse trabalho, qual seja, a de que as séries de preço bem representam a tendência hidrológica em cada caso analisado. De fato, ao não se dispor do modelo de hidrologias inserido no NEWAVE (modelo DESAG) para permitir que se trabalhasse com séries de energias afluentes ao invés do preço, assumiu-se a premissa de que as séries de preço são sinalizadoras aceitáveis da tendência hidrológica, daí porque se trabalhou com séries de PLD / CMO e não de Energias Naturais Afluentes - ENA's.

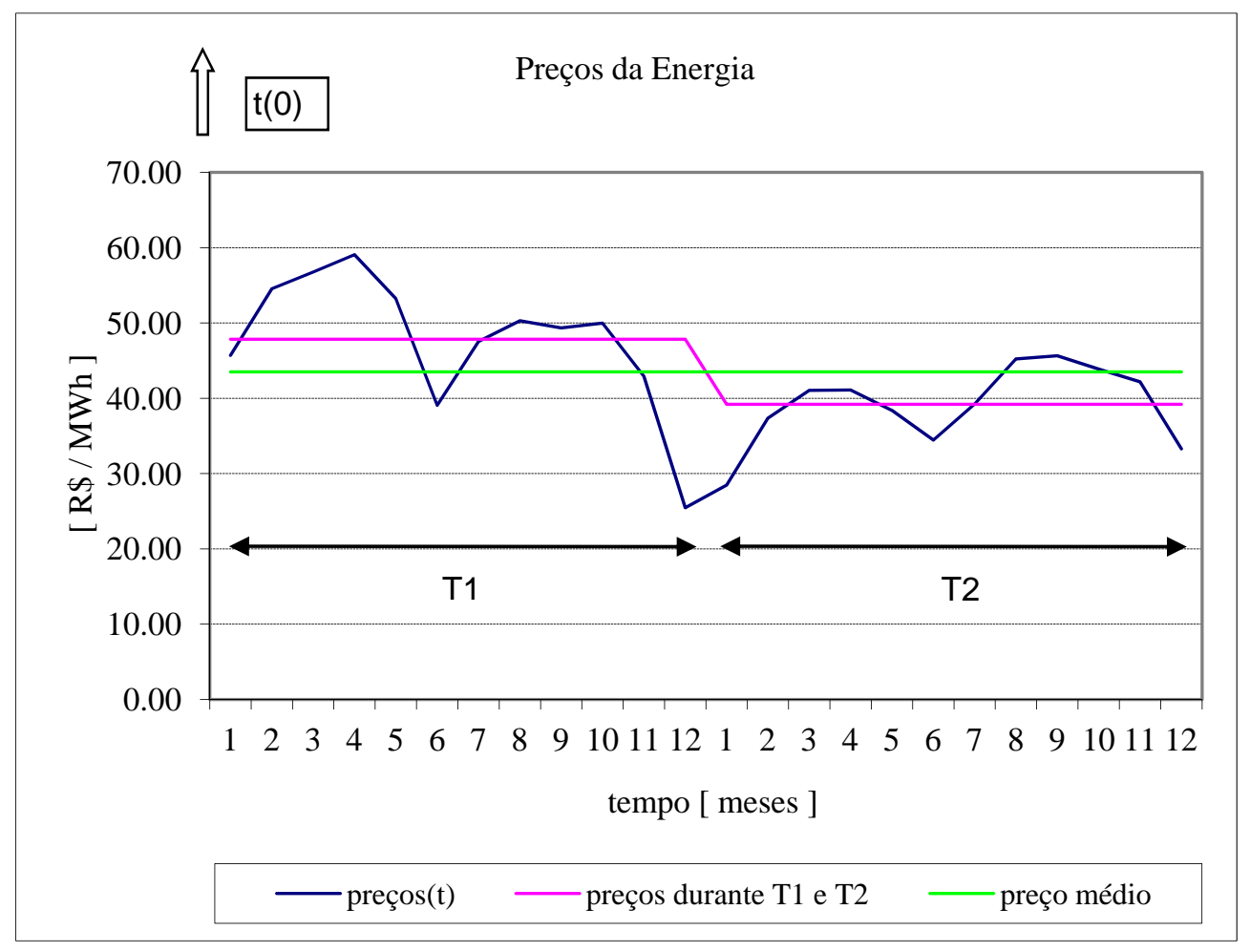

Gráfico 5.2 - Exemplificação do procedimento de formação do preço dos contratos com vigência de dois anos 


\subsubsection{Contratos com vigência de três, quatro e cinco anos}

Nos contratos com duração de três ou mais anos, o preço dos contratos obedece à seguinte lei de formação: os dois primeiros anos do contrato são calculados utilizandose o mesmo método para os contratos de dois anos, já para o terceiro ano em diante, o preço da energia é o próprio custo da energia nova. Este valor é definido como dado de entrada da simulação, de modo a refletir o custo unitário incorrido nos projetos de expansão da oferta de energia do Parque Gerador Brasileiro.

A precificação do contrato pode, então, ser calculada pela média dos valores presentes do primeiro, do segundo e do terceiro ano a frente do instante de recontratação. Essa dinâmica para a síntese do valor contratual é, também, usada para os contratos com quatro e cinco anos de duração, onde, da mesma forma, se aplica a equação (5) para a implementação destes preços contratuais.

O fluxograma para a formação dos preços contratuais com duração de três, quatro e cinco anos é apresentado na Figura 5.6.

A seguir, é exemplificada a metodologia empregada na constituição dos preços contratuais com vigência de três, quatro ou cinco anos, onde no instante de início da contratação ( $\left.t_{0}\right)$, monitora-se a expectativa dos preços da energia para os próximos dois anos, utilizando os valores encontrados, mais o custo marginal de expansão (CME), para compor as parcelas de preços dos contratos referentes ao terceiro, quarto ou quinto ano de cobertura do contrato, de acordo com o Gráfico 5.3. 


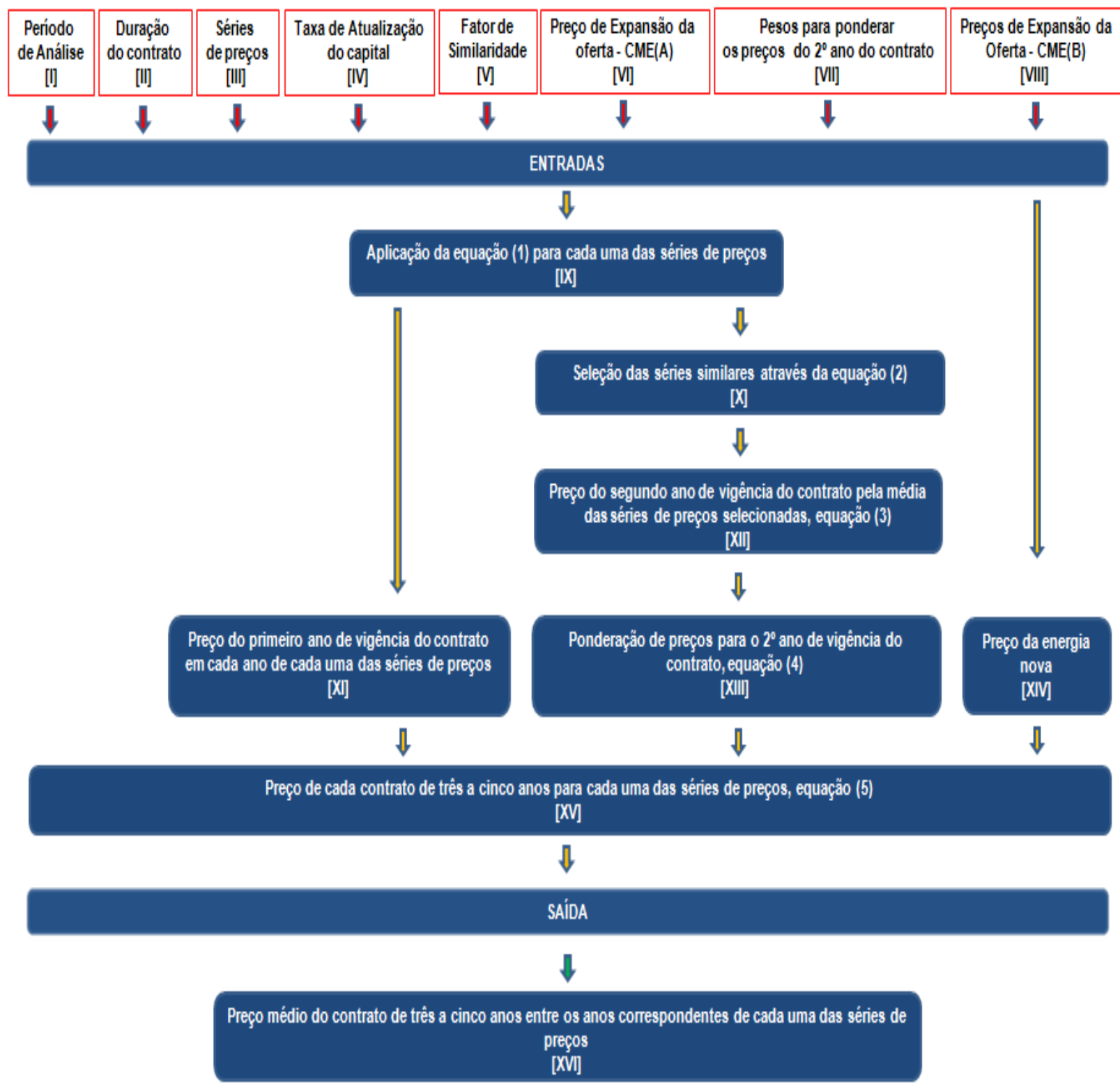

Figura 5.6 - Fluxograma de formação do preço dos contratos com duração variando entre 3 e 5 anos

Onde:

[ l ] - Período de análise - corresponde ao horizonte de tempo a ser considerado na simulação da contratação de energia;

[ II ] - Duração do contrato - denota o tempo de vigência da modalidade contratual;

[ III ] - Séries de preços - indicam as séries de preços extraídas do software NEWAVE; 
[ IV ] - Taxa de atualização do capital - refere-se à taxa de juros considerada para a atualização monetária;

[ V ] - Fator de similaridade - fator de similaridade para definição das hidrologias aceitáveis (p.u.);

[ $\mathrm{VI}$ ] - Preço de expansão da oferta de energia $\operatorname{CME}(\mathrm{A})$ - refere-se ao custo marginal de expansão com prazo de entrega de energia compatível com o horizonte de dois anos. Este valor é o preço definido nos Leilões de energia: A-3, Existente, Ajuste ou Geração Distribuída;

[ VII ] - Pesos para formar o preço do $2^{\circ}$ ano do contrato - estes valores são utilizados para ponderar o $2^{\circ}$ ano de vigência do contrato entre o preço de curto prazo e também pelo custo marginal de expansão definido em [ VI ];

[ VIII ] - Preço de expansão da oferta de energia $\operatorname{CME}(B)$ - refere-se ao custo marginal de expansão com prazo de entrega de energia compatível com o horizonte de três, quatro ou cinco anos. Este valor é o preço definido nos Leilões de energia nova: A-5;

[ IX ] - Cálculo do preço anual - etapa que indica a aplicação da equação (1) para o cálculo do preço anual dentro de cada uma das séries de preços do NEWAVE;

[X ] - Seleção das séries de preços similares - através da aplicação da equação (2);

$[\mathrm{XI}]$ - Definição do preço do $1^{\circ}$ ano de vigência do contrato - nesta etapa é formado o preço referente à parcela do $1^{\circ}$ ano que irá compor o valor do contrato de três, quatro ou cinco anos de duração;

[ XII ] - Definição do preço do 20 ano de vigência do contrato - nesta etapa é formado o preço referente à parcela do $2^{\circ}$ ano que irá compor o valor do contrato de três, quatro ou cinco anos de duração;

[ XIII ] - Ponderação para ajustar o preço do $2^{\circ}$ ano de vigência do contrato - o preço referente à parcela do $2^{\circ}$ ano é formado pelo mix de preço spot associado ao $2^{\circ}$ ano, mesclado com o valor do custo marginal de expansão definido em [ VI ];

[ XIV ] - Preço de expansão da oferta de energia $\mathrm{CME}(\mathrm{B})$ - refere-se ao custo marginal de expansão com prazo de entrega de energia compatível com o horizonte de três, quatro ou cinco anos. Este valor é o preço definido nos Leilões de energia nova: A-5; 
[ XV ] - Cálculo do preço do contrato com três, quatro ou cinco anos de vigência - forma-se o preço contratual de três, quatro ou cinco anos pela aplicação da equação (5), que contempla as parcelas calculadas nas etapas [ XI ], [ XIII ] e [ XIV ];

[ XVI ] - Preço Médio dos contratos de três, quatro ou cinco anos de duração - finalmente, são disponibilizados os preços médios dos contratos de três, quatro ou cinco anos para o horizonte de simulação. De modo que, cada contrato de três, quatro ou cinco anos de duração, é a média aritmética, no horizonte de tempo correspondente, entre todos os contratos de três, quatro ou cinco anos de vigência nas diversas séries de preços consideradas.

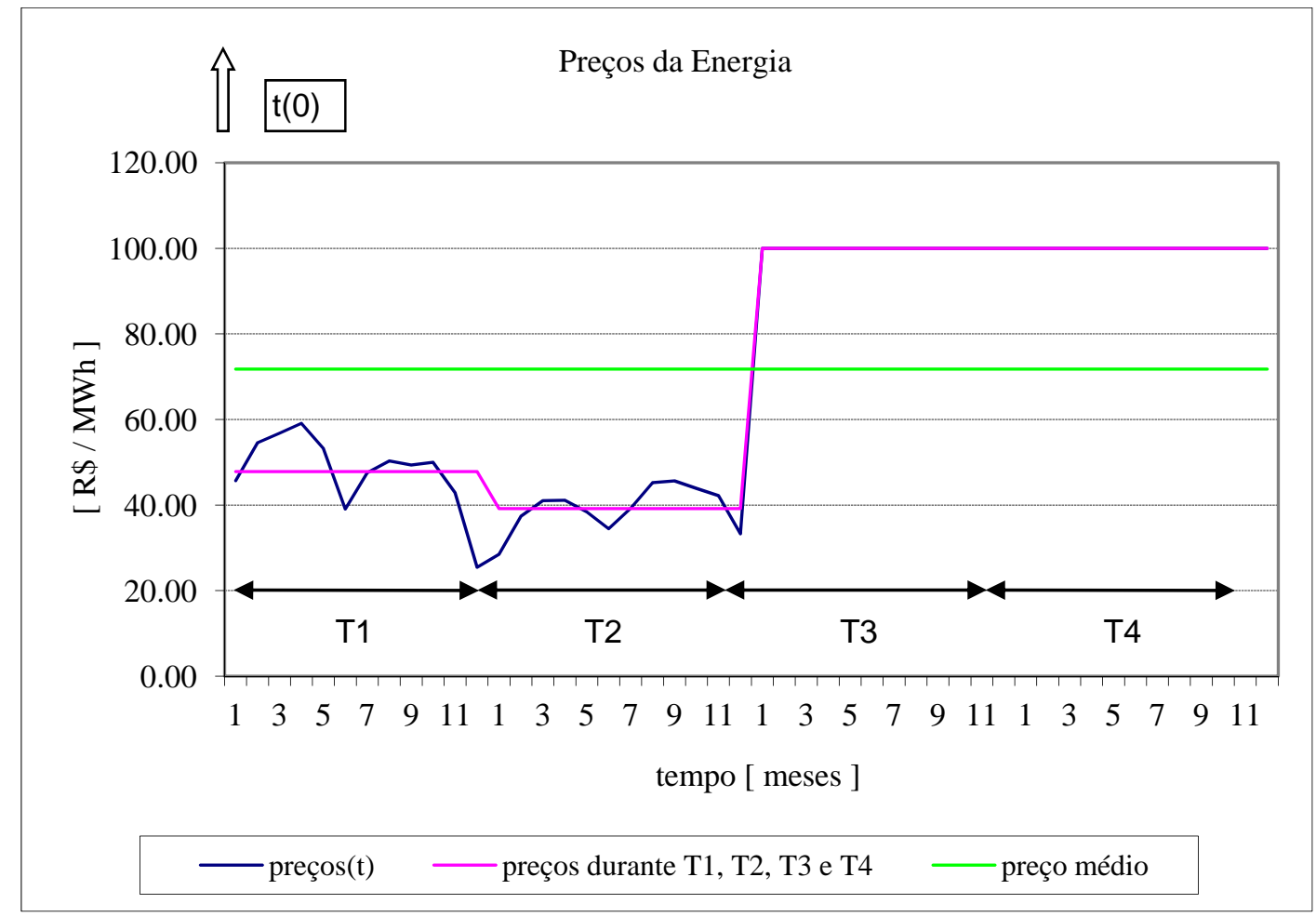

Gráfico 5.3 - Exemplificação do procedimento de formação do preço dos contratos com vigência de três ou mais anos

\subsubsection{Contratos com vigência fracionária}

Para se estabelecer um contrato com vigência fracionária, como por exemplo, 2 anos e 5 meses, a metodologia precedente deve ser aplicada na forma proposta, com o 
cuidado de que, para ponderar o ano fracionado, devem ser considerados apenas os meses correspondentes na formação do preço anual e, depois, na aplicação da equação (5) deve-se afetar o preço anual por um peso igual à fração (no de meses do ano fracionado / 12).

\subsection{DEFINIÇÃO DA ATIVIDADE ECONÔMICA}

Para emular o comportamento econômico do setor de atividade no qual o Consumidor Livre esteja inserido, foram definidas três distribuições normais de probabilidade, geradas a partir de extrações de números aleatórios pelo método de Monte Carlo.

\subsubsection{A redução do consumo de energia}

A redução do consumo de energia está representada por uma distribuição normal de probabilidades, que caracteriza o comportamento médio de redução do consumo de energia do Consumidor Livre quando este é afetado por um evento que impacte a sua demanda. Para a implementação dessa distribuição de probabilidades, são definidos como dados de entrada, a redução média do consumo $\left(E_{r}\right)$ como uma porcentagem do valor total demandado pelo consumidor, o desvio padrão da redução média do consumo $\left(\sigma_{E r}\right)$ e o número de ocorrências (ensaios) a serem considerados para representar estatisticamente essa distribuição $(N)$. O valor da redução de demanda é uma fração do consumo total do Cliente Livre e, portanto é definido em p.u.

\subsubsection{A duração da redução de consumo de energia}

Esta segunda distribuição normal de probabilidades determina a duração média da redução de consumo, em meses, de um Consumidor Livre quando da ocorrência do evento de redução de sua demanda. 
Neste caso, são definidos como dados de entrada, a duração média da redução de consumo $\left(E_{d}\right)$, o desvio padrão desta mesma variável $\left(\sigma_{E d}\right)$ e o número de ocorrências (ensaios) a serem considerados para representar estatisticamente essa distribuição $(M)$.

\subsubsection{O tempo até a ocorrência do evento que provoca a redução de consumo de energia}

Outra variável considerada na determinação do perfil de consumo do Consumidor Livre é o tempo médio, também expresso em meses, que marca o intervalo desde a efetivação da primeira contratação, em $t(0)$, ou final de um evento de redução de consumo, até o início de um próximo evento que reduza o valor de consumo firmado originalmente.

Novamente, são definidos como dados de entrada, o delay médio de início de um evento que afeta a demanda do consumidor $\left(E_{a}\right)$, o seu desvio padrão $\left(\sigma_{E a}\right)$ e o número de ocorrências (ensaios) a serem considerados para representar estatisticamente essa distribuição $(N)$.

\subsubsection{Caracterização do perfil de consumo de energia do Consumidor Livre}

As três variáveis independentes descritas anteriormente são caracterizadas por distribuições normais de probabilidade, com média, desvio padrão e número de observações atribuídos no início da simulação, de tal forma que sintetizarão o comportamento médio do nível de atividade econômica do setor no qual o consumidor pertença ao longo do período de análise comparativo de 10 anos. 
Dessa maneira, adotados os parâmetros para estas três distribuições normais de probabilidade, Figura 5.7, realiza-se um processo iterativo para modular o perfil de consumo do Cliente Livre ao longo do horizonte de estudo de 10 anos.

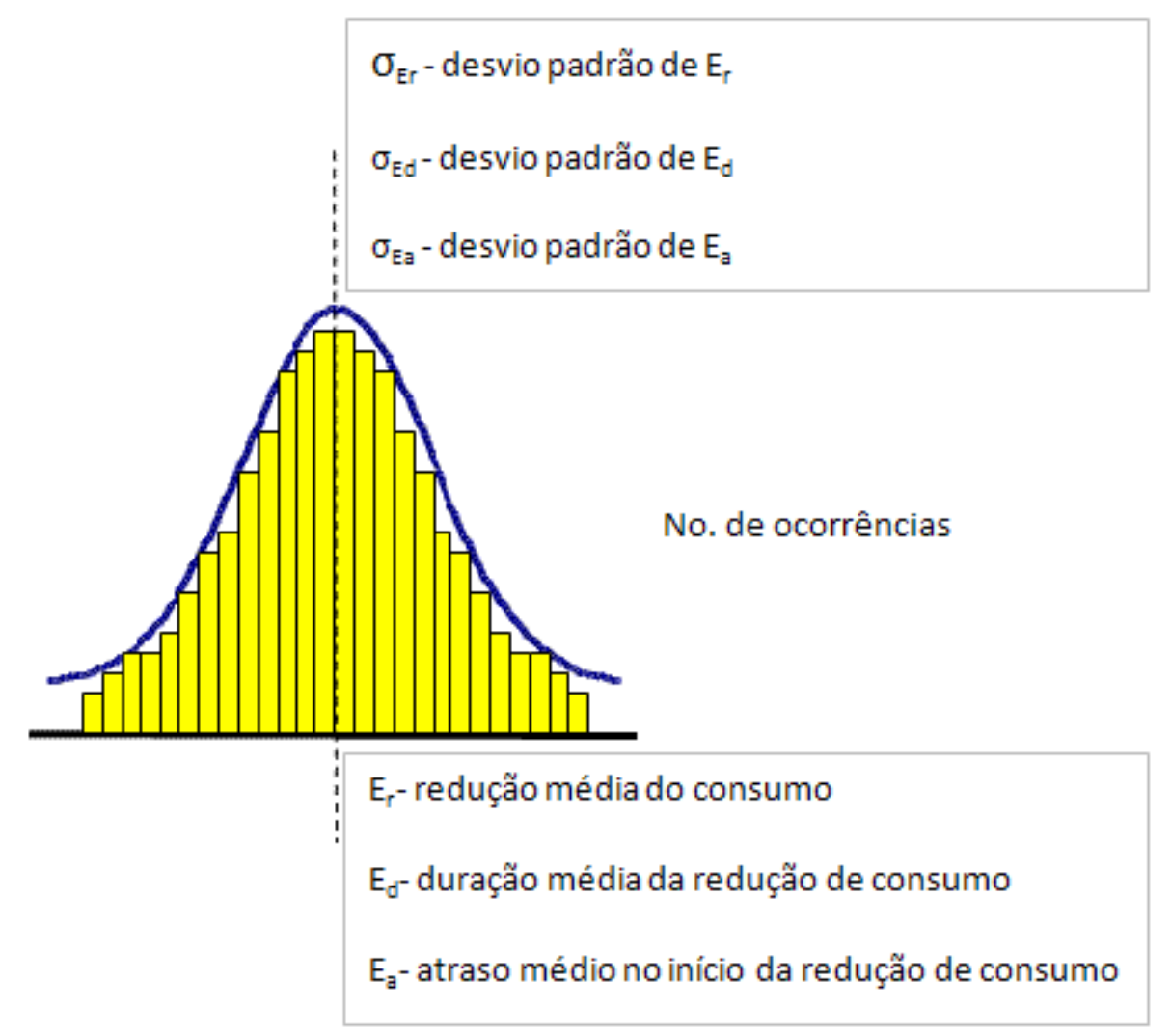

Figura 5.7 - Exemplo de distribuição normal de probabilidades para caracterizar o perfil de consumo de energia do Consumidor Livre

O procedimento para a construção do perfil de consumo do agente livre é iniciado pelo sorteio de uma amostra de cada uma das três distribuições de probabilidades disponíveis, de tal modo que se seleciona primeiro o intervalo de tempo que representa, em meses, o tempo desde o instante da primeira contratação, $\mathrm{t}(0)$, até a ocorrência do primeiro evento de redução de consumo de energia. 
Na sequência, é sorteada uma nova amostra, agora da distribuição de probabilidades que indica o valor da redução de consumo, em p.u, enfrentada pelo Consumidor Livre. E, finalmente, escolhe-se também, aleatoriamente, uma amostra dentro da distribuição de probabilidades que representa a duração da redução de consumo a que o Consumidor Livre estará submetido nesta ocasião.

O processo é então repetido até que seja coberto todo o horizonte temporal de análise, sendo este igual a 10 anos. O fluxograma indicativo desta metodologia está descrito na Figura 5.8, para o qual se aplica a seguinte notação:

[ I ] - Instante $\mathrm{t}(0)$ - define o instante da primeira contratação de energia e início da simulação considerando o horizonte de tempo igual a 10 anos;

[ II ] - Etapa de sorteio - início da seleção de dados das distribuições de probabilidades normais definidas como dados de entrada da simulação;

[ III ] - Primeiro sorteio - corresponde à escolha aleatória de uma amostra da distribuição de probabilidades que define o tempo desde a primeira contratação de energia ou final de um evento de redução de consumo até a ocorrência de um próximo evento que provoca a redução de consumo;

[ IV ] - Segundo sorteio - define a escolha aleatória de uma amostra da distribuição de probabilidades que representa o valor da redução de consumo de energia em p.u;

[ V ] - Terceiro sorteio - indica a escolha aleatória de uma amostra da distribuição de probabilidades que determina o tempo de permanência da redução de consumo de energia, em meses;

$[\mathrm{VI}$ ] - Perfil de consumo de energia no instante $\mathrm{t}(\mathrm{t})$ - até este instante de tempo t, o perfil de consumo do Cliente Livre está definido;

[ VII ] - Verificação do fim do período de análise - caso o instante de tempo t seja igual a 120 meses, o processo iterativo está concluído e, não são mais sorteadas amostras das distribuições normais de probabilidades. Caso contrário, o processo é reiniciado até que a condição de fim do período de análise seja satisfeita; 
[ VIII ] - Perfil de consumo para todo o período de análise - quando a condição da etapa VII é atendida, está construído e mapeado o perfil de consumo de energia do Consumidor Livre para todo o horizonte temporal de análise que é de 10 anos.

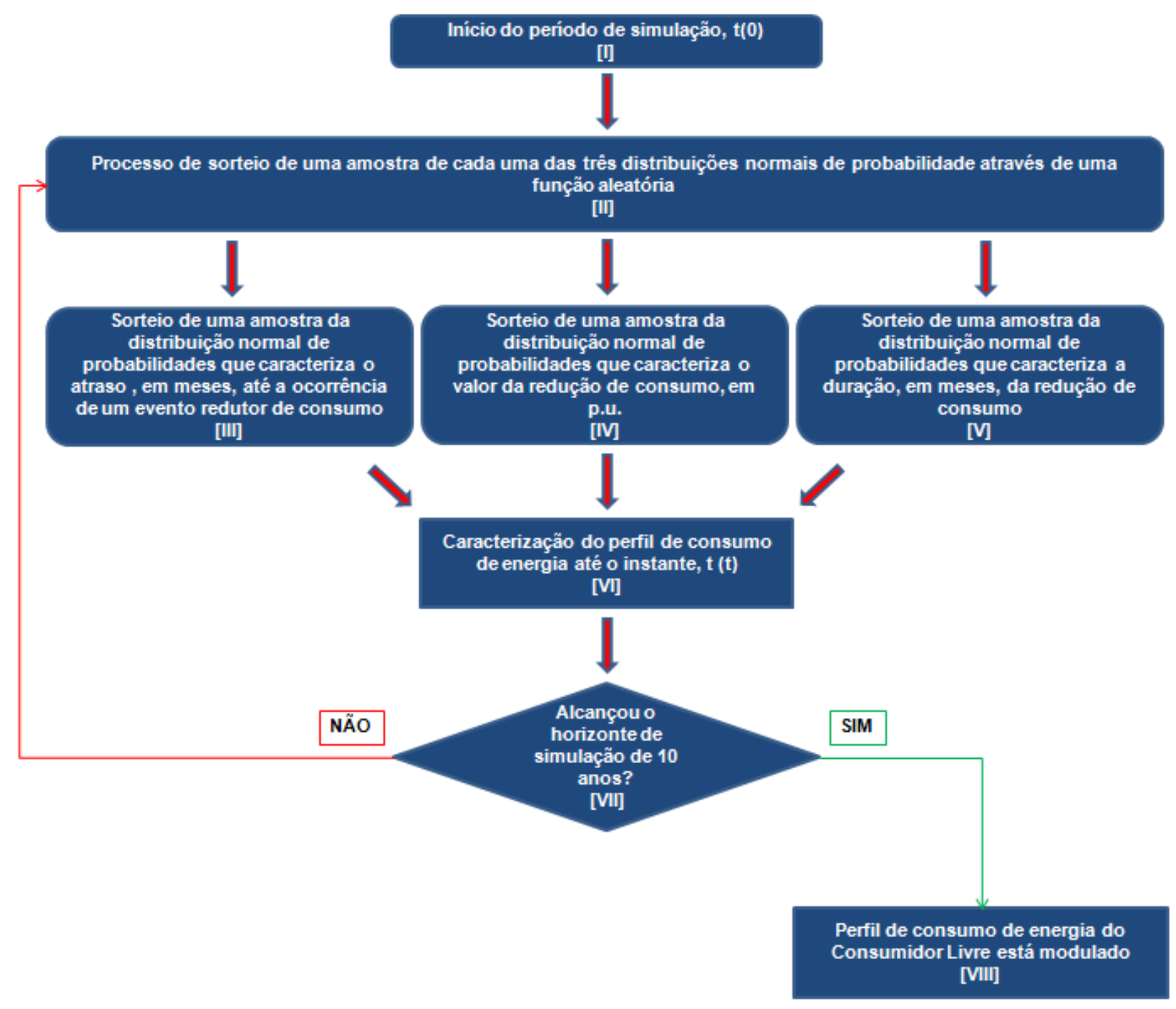

Figura 5.8 - Fluxograma indicando a caracterização do perfil de consumo de energia do Consumidor Livre

A seguir se apresenta, no Gráfico 5.4, um exemplo de perfil de consumo de energia modulado a partir do processo descrito nesta seção. 


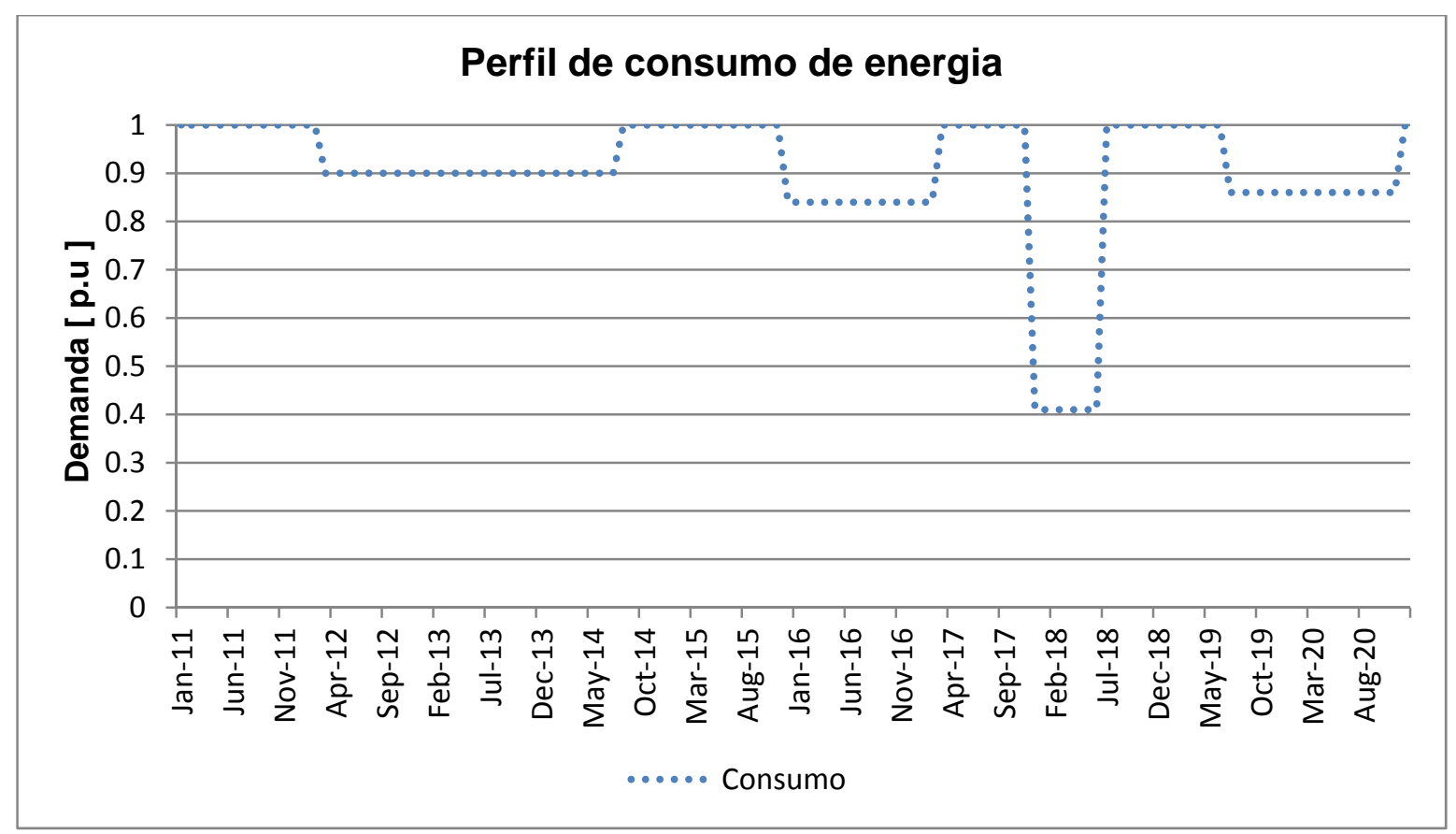

Gráfico 5.4 - Exemplificação de perfil de consumo de energia do Consumidor Livre

\subsection{A CESSÃO DOS EXCEDENTES CONTRATUAIS E SUA PRECIFICAÇÃO}

Os montantes de energia a serem descontratados pelos consumidores devem seguir limites pré-definidos dos contratos celebrados e registrados na Câmara de Comercialização de Energia Elétrica (CCEE):

- Até $10 \%$ da energia contratada para contratos de menos de 2 anos;

- Até $20 \%$ para contratos entre 2 e 5 anos;

- Até 50\% para contratos de 5 a 10 anos.

Adicionalmente, impõe-se que na ocasião de uma redução de demanda, independente da sua duração, o Consumidor Livre cederá o seu montante excedente em um contrato cujo término seja coincidente com o prazo de vigência do contrato que o originou. 
Os preços dos contratos excedentes seguem as mesmas regras de formação dos preços de contratos definidos anteriormente, na seção 5.4 - Precificação dos contratos, com a ressalva de que estes são aplicados no momento em que os excedentes se apresentam e, terão suas durações compreendidas entre o início da redução e o instante de renovação do contrato original. Ou seja, existe sempre a concatenação entre o prazo de vencimento do contrato de venda do excedente e o prazo de vigência do contrato de energia que o concretizou.

Posto desta maneira, uma vez simulado o perfil de consumo de energia do Consumidor Livre ao longo do horizonte de análise de 10 anos, estão caracterizados, (i) o instante de tempo que marca o início da realização do excedente contratual, (ii) o volume de energia a ser cedido nesta ocasião e (iii) a sua respectiva duração. Uma vez definidos estes parâmetros, particularizados para cada ocorrência de uma cessão contratual, existirão as seguintes possibilidades para a venda dos excedentes contratuais, em todas as modalidades de contrato aqui contempladas:

- Primeira Possibilidade: A duração da redução de consumo simulada (que terá que ser acomodada por uma cessão de contrato vigente em volume equivalente) é menor do que o prazo de vigência original do contrato. Neste caso, o Consumidor Livre cede seus excedentes contratuais por igual período do contrato original. A compra de energia no horizonte de tempo compreendido entre o término da redução de consumo e o vencimento da modalidade contratual analisada, é realizada no mercado, através da aquisição de novos contratos, considerando-se duas hipóteses: 
- (i) vigência igual àquela que reflete o período entre o início da retomada da demanda e o final do contrato majoritário que esteja vigente, representado na Figura 5.9 e

- (ii) compra de contratos de duração reduzida no mercado de curto prazo, ilustrado na Figura 5.10.

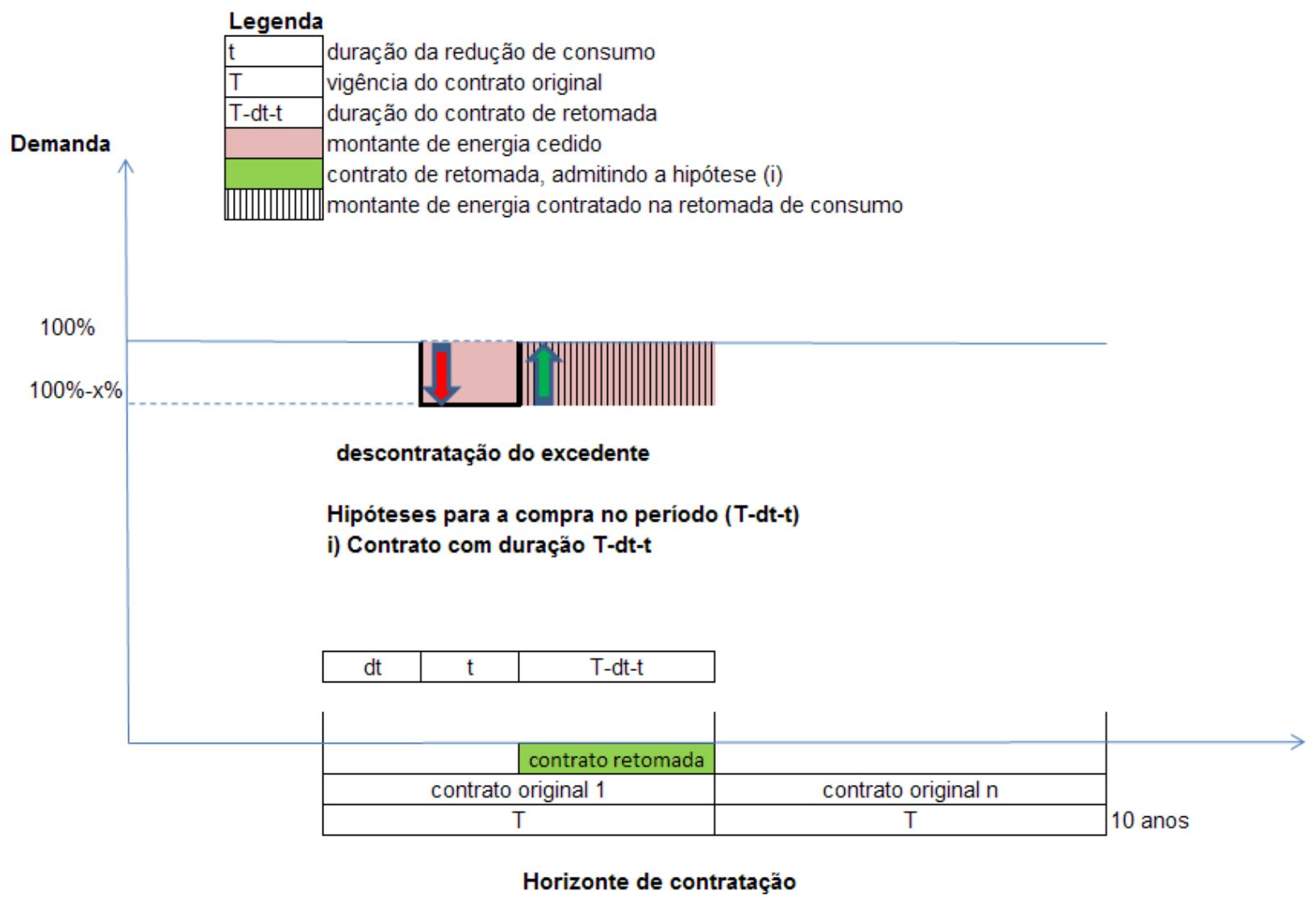

Figura 5.9 - Exemplificação da cessão de excedente contratual adotando a hipótese (i) 


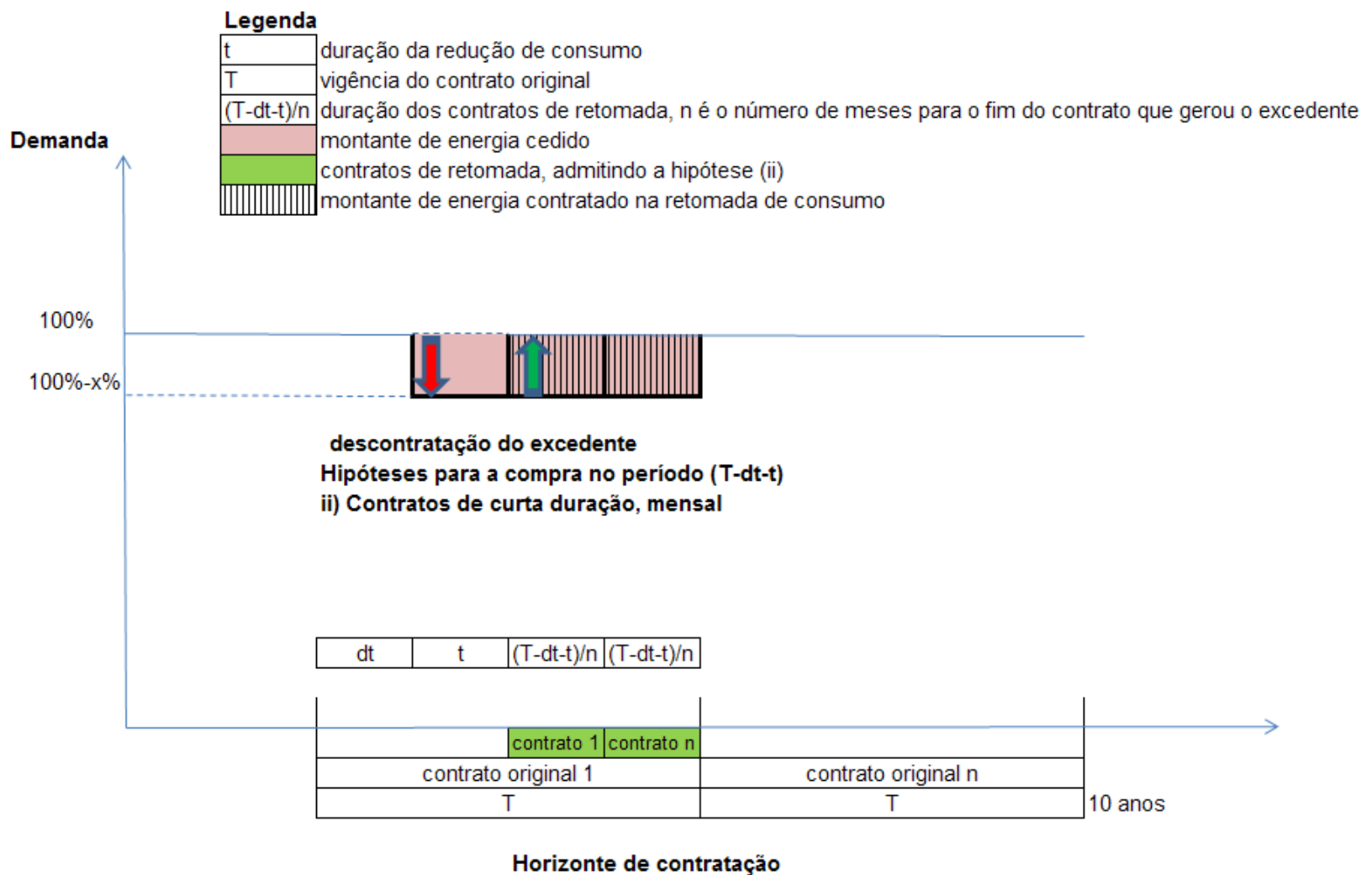

Figura 5.10 - Exemplificação da cessão de excedente contratual adotando a hipótese (ii)

- Segunda Possibilidade: A duração da redução de consumo simulada é maior do que o prazo de vigência original do contrato. Nesta situação, o Consumidor Livre também cede os seus excedentes contratuais por igual período do contrato original. E, na renovação contratual, adquire novo acordo, com montante coerente, absorvendo a redução do seu consumo. Além disso, a compra de energia no horizonte de tempo compreendido entre o início da retomada de consumo até o fim da modalidade contratual que esteja vigente, obedecerá as mesmas duas hipóteses, (i) e (ii), do caso anterior. A exemplificação desta segunda possibilidade adotando a hipótese (i) está ilustrada na Figura 5.11. Já a hipotése (ii) para esta mesma possibilidade está representada na Figura 5.12. 
- De modo a resumir a metodologia de cessão dos excedentes contratuais aqui implementada, é apresentado o fluxograma da Figura 5.13, onde estão ilustradas as duas possibilidades vislumbradas quanto a duração da redução de demanda por energia do consumidor e, também, as duas hipóteses que balizam a compra de energia através de contratos de retomada na eventualidade de reestabelecimento do consumo por parte do Cliente Livre. É importante frisar que as regras de formação de preços para aquisição de contratos de retomadas de consumo são as mesmas descritas na seção 5.4 - Precificação dos contratos.

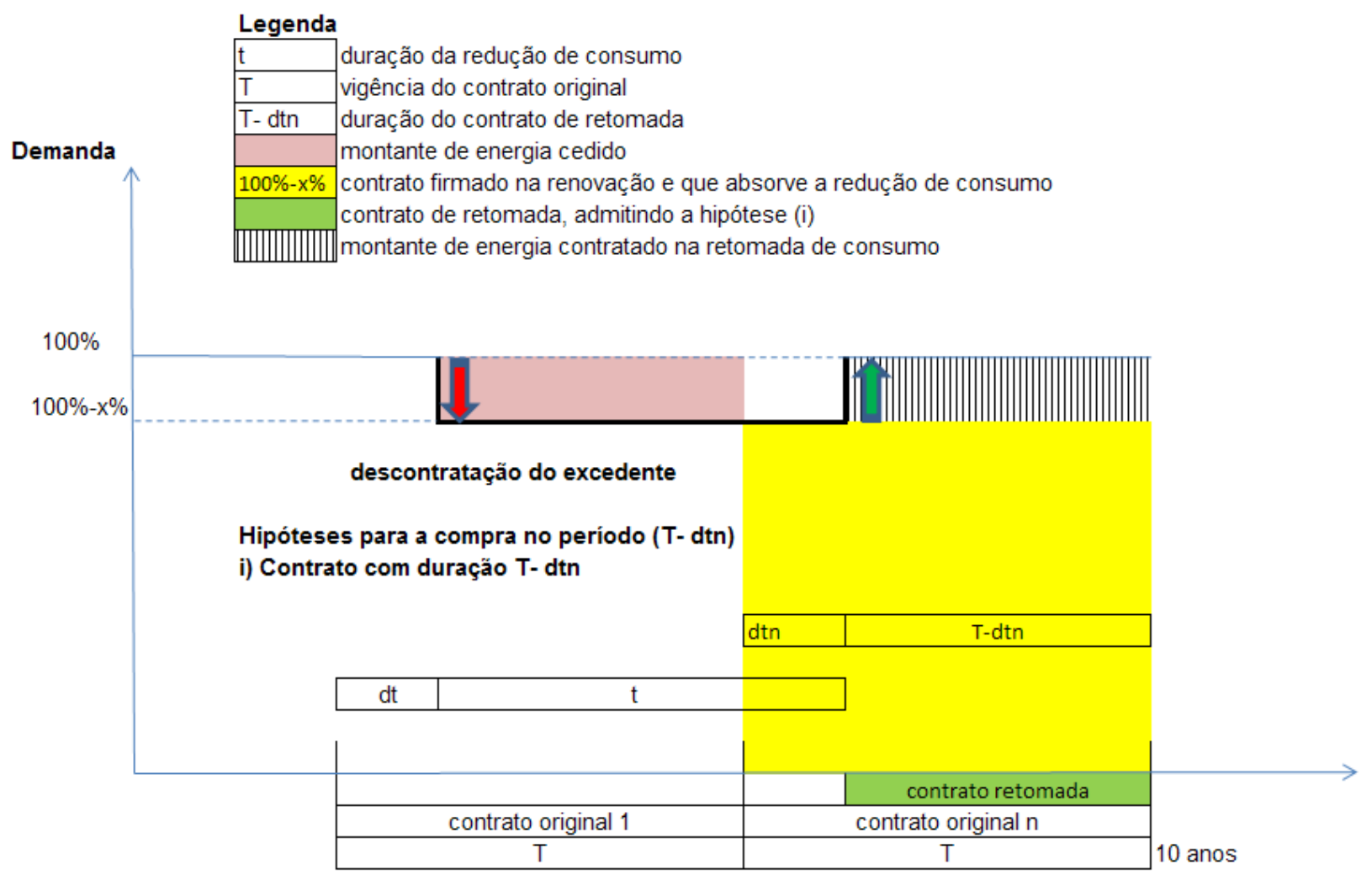

Horizonte de contratação

Figura 5.11 - Exemplificação da cessão de excedente contratual adotando a hipótese (i) 


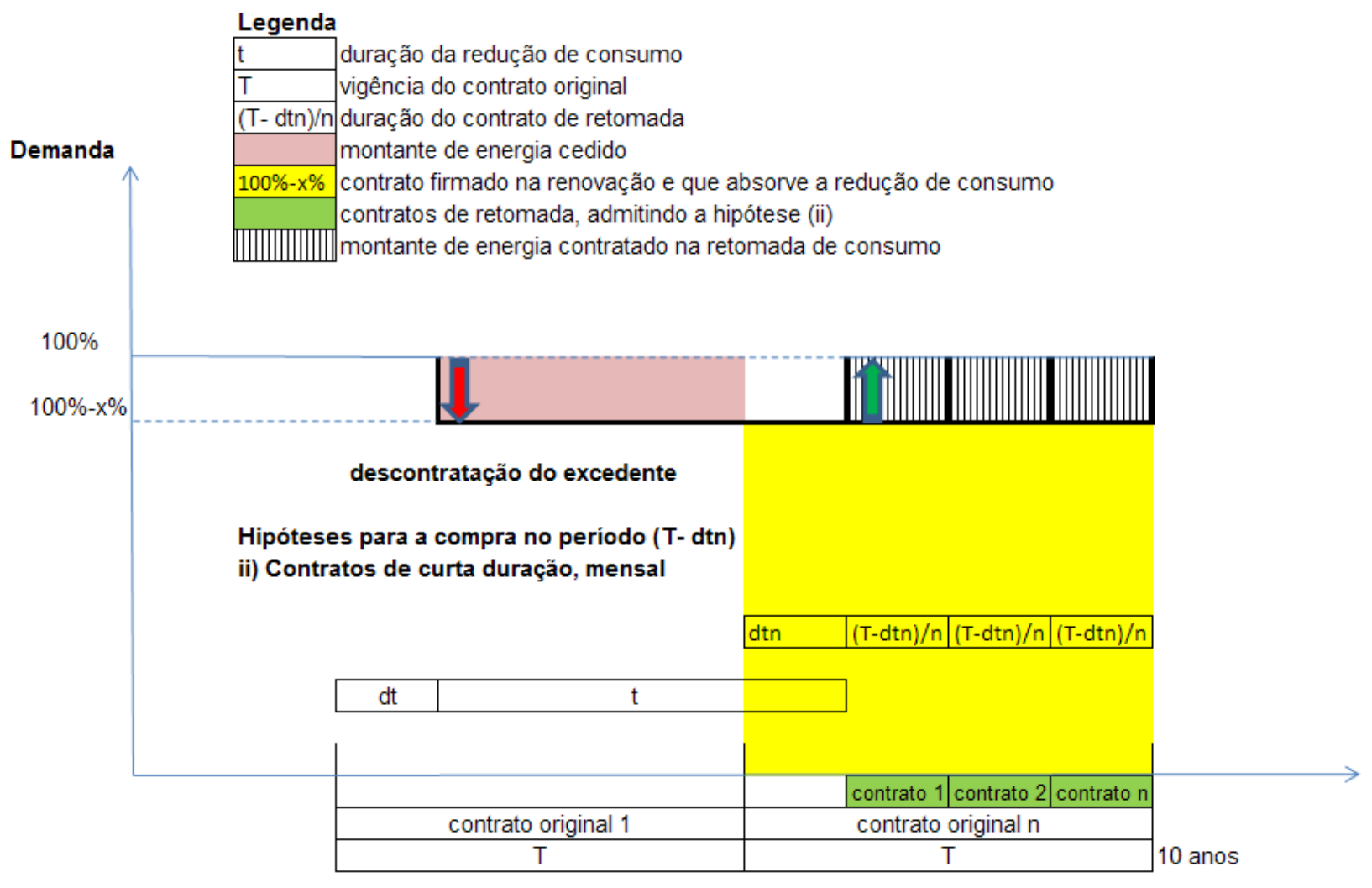

Horizonte de contratação

Figura 5.12 - Exemplificação da cessão de excedente contratual adotando a hipótese (ii)

Para o Fluxograma da Figura 5.13 a seguir, aplica-se a seguinte notação:

[ I ] - O perfil de consumo de energia é analisado e identifica-se o instante de tempo no qual o excedente de energia se apresenta;

[ II ] - No momento de ocorrência da cessão do excedente contratual, verifica-se a duração da redução de consumo de energia;

[ III ] - Nesta etapa, exerce-se a venda da sobra de energia com o montante limite determinado pela duração do contrato que originou o excedente. O preço de venda do contrato excedente segue a lógica proposta na seção 5.4 Precificação dos contratos; 


\section{METODOLOGIA PARA A VENDA DE EXCEDENTES CONTRATUAIS}

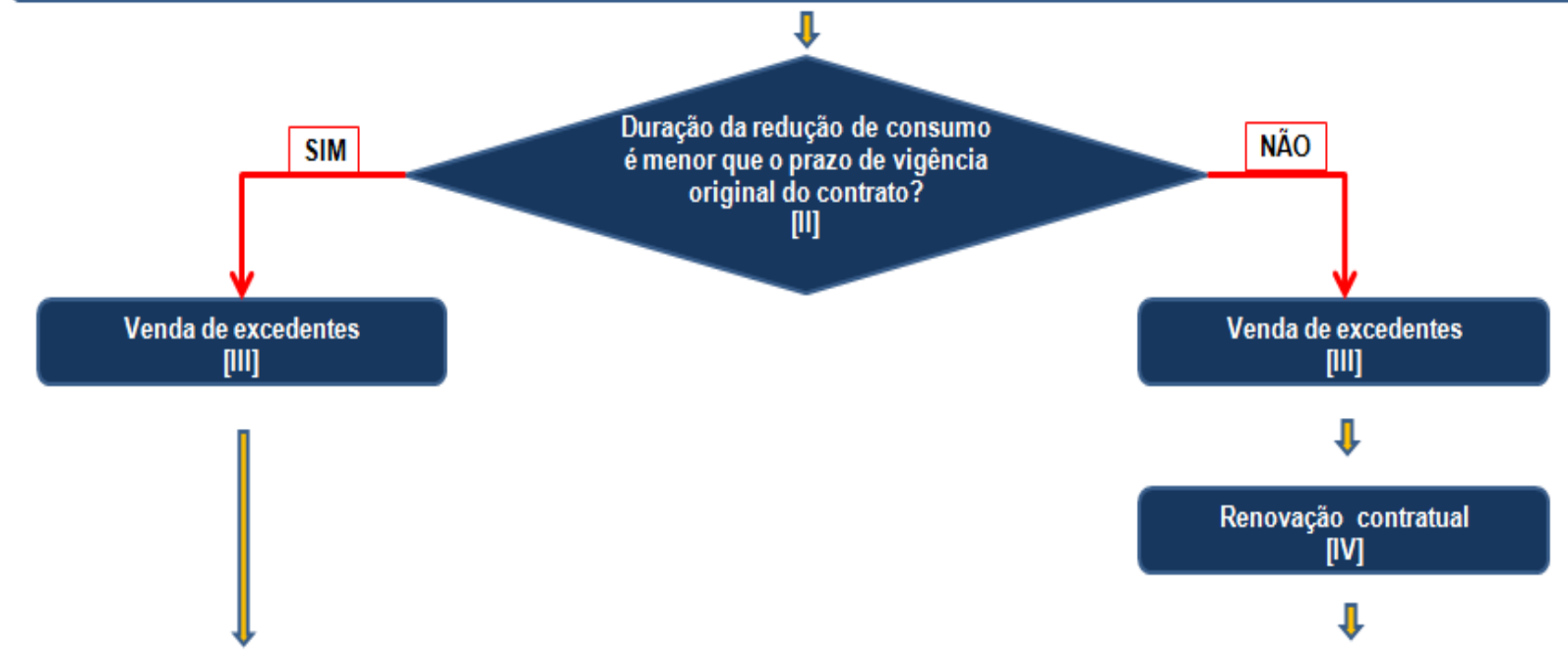

RETOMADA DO CONSUMO DE ENERGIA
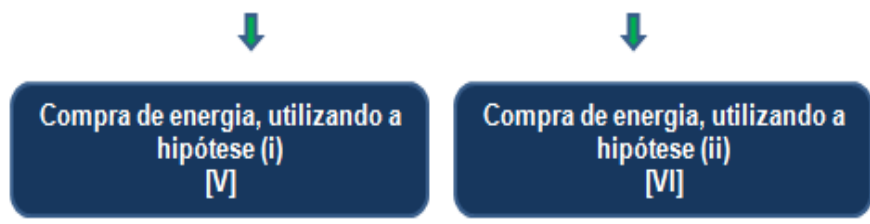

Figura 5.13 - Fluxograma da metodologia de cessão dos excedentes contratuais de energia

[ IV ] - Caso a duração da redução de consumo supere o prazo de vigência do contrato que originou o excedente de energia, na renovação do contrato, qual seja a modalidade contratual escolhida, o montante de energia a ser contratado já considera a redução de energia para este novo acordo a ser firmado;

[ V ] - Quando existe uma retomada de consumo, a compra de energia no horizonte de tempo compreendido entre o término da redução de consumo e o fim do horizonte de estudo da modalidade contratual vigente, é realizada no mercado, através da aquisição de novos contratos. Considerando-se a hipótese (i), a vigência deste contrato de retomada é igual àquela que reflete o período entre $\mathrm{o}$ início da retomada da demanda e o final do contrato majoritário que originou o excedente de energia. O preço de compra do contrato de retomada, que garante o lastro para a energia consumida, segue a lógica proposta na seção 5.4 Precificação dos contratos; 
[ VI ] - Quando existe uma retomada de consumo de energia, a compra de energia no horizonte de tempo compreendido entre o término da redução de consumo e o fim do horizonte de estudo da modalidade contratual vigente, é realizada no mercado, através da aquisição de novos contratos. Considerando-se a hipótese (ii), a vigência destes contratos de retomada é mensal e, o número de contratos é igual àquele que reflete os meses entre o início da retomada da demanda e o final do contrato majoritário que originou o excedente de energia. O preço de compra dos contratos de retomada, que garantem o lastro para a energia consumida, segue a lógica proposta na seção 5.4 Precificação dos contratos.

\subsection{DEFINIÇÃO DOS RISCOS FINANCEIROS}

\subsubsection{Parâmetros de risco de preços}

O risco de preços quantificado nesta simulação envolve dois parâmetros, os quais definem as faixas de preços de acordo com o grau de aversão ao risco de determinado Consumidor Livre e, consequentemente, impõem o seu limite de exposição financeira em cada modalidade contratual.

O primeiro indicador, denominado Preço da Energia Nova - PEN, é definido como um dado de entrada da simulação e determina um valor de referência para o preço de expansão da oferta do parque de geração de energia. O segundo indicador, chamado Preço Máximo Admissível - PMA, determina o preço, também indicado pelo cliente, sobre o qual é associado um valor de probabilidade aceitável para todos àqueles preços contratuais que forem classificados como superiores ao valor de PMA. Portanto, os dois parâmetros delineiam faixas de preços de acordo com a Figura 5.14.

A primeira faixa de preços, preços admissíveis, contempla os preços menores ou iguais a PMA. Já a segunda faixa, contempla os preços "não" admissíveis, onde preços acima 
de PMA são enumerados e, em função da amostragem obtida, calcula-se a média dos preços máximos, PMM, pertencentes à esta faixa, além de ser mensurada, também, a probabilidade de ocorrência dos preços maiores que PMA, que implementam o risco médio - RM.

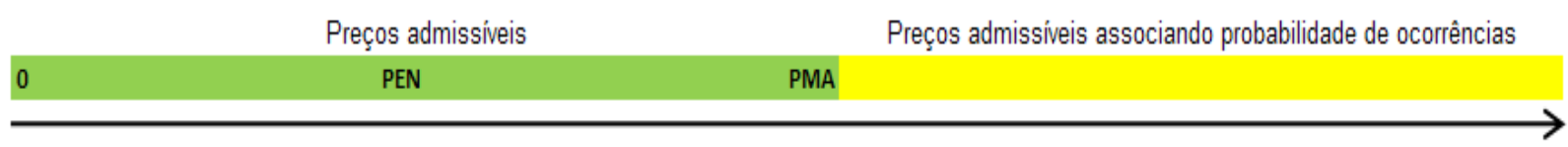

[RS/ MWh ]

Figura 5.14 - Faixas de preços para o cálculo do risco de preços

Onde:
[PEN] - Preço da Energia "Nova", R\$/MWh;
[ PMA ] - Preço Máximo Admissível, R $\$ / M W h$.

\subsubsection{Definição do preço dos contratos ponderado pelo MWmed}

Como mencionado na seção anterior, optou-se por ilustrar a metodologia e potencial de análise, enfocando-se a probabilidade de ocorrência de valores de preço de contratos de compra de energia acima do Preço Máximo Admissível, para cada uma das estratégias contratuais de aquisição de energia.

É importante ressaltar que o preço de um contrato, independente do momento que este é firmado, seja este (i) em uma condição de renovação contratual ou (ii) em situação de aquisição de um contrato adicional que lastreie a retomada do consumo dentro de uma modalidade contratual escolhida, é calculado levando-se em consideração a sua ponderação pelo montante de energia (MWmed) a ser contratado em relação ao preço 
médio do portfólio de contratos até então constituído pelo Consumidor Livre. Para descrever o cálculo do preço do contrato ponderando-se o montante de energia a ser contrato (MWmed), são exemplificadas as duas condições para a compra de energia apontadas acima:

- Renovação contratual (i): Nesta situação, o Consumidor Livre está contratando a totalidade de sua carga. Dessa maneira, definindo a carga do consumidor como $\mathrm{D}$ e o preço do contrato de energia disponível no mercado como $\mathrm{P}$, a equação (6) dita o preço do MWmed. A Figura 5.15 ilustra a aplicação desta fórmula.

$$
P_{M W m e d}=\frac{P * D}{D}=P
$$

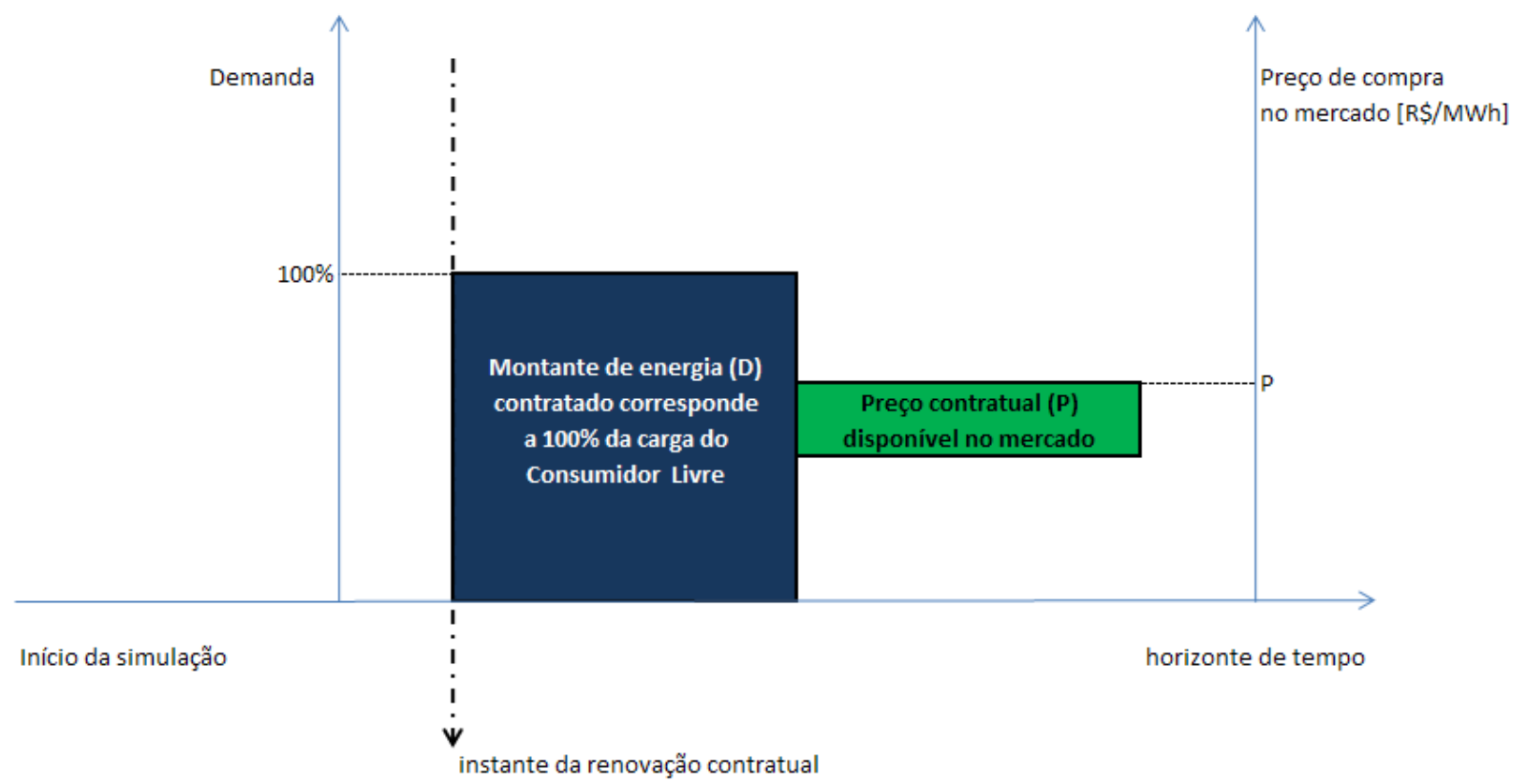

Figura 5.15 - Renovação contratual e o preço do MWmed 
- Adicional contratual (ii): Já nesta situação, o Consumidor Livre já possui outros contratos que lastreiam sua demanda energética $D_{1}$, a um preço médio da sua carteira de contratos $P_{1}$. No entanto, em um momento seguinte há um acréscimo em sua carga $D_{2}$, sendo o preço do contrato de energia ofertado no mercado $P_{2}$. Para esta situação, o preço do MWmed é dado pela equação (7) e, a Figura 5.16 exemplifica a sua aplicação.

$$
P_{M W m e d}=\frac{D_{1} * P_{1}+D_{2} * P_{2}}{D_{1}+D_{2}}
$$

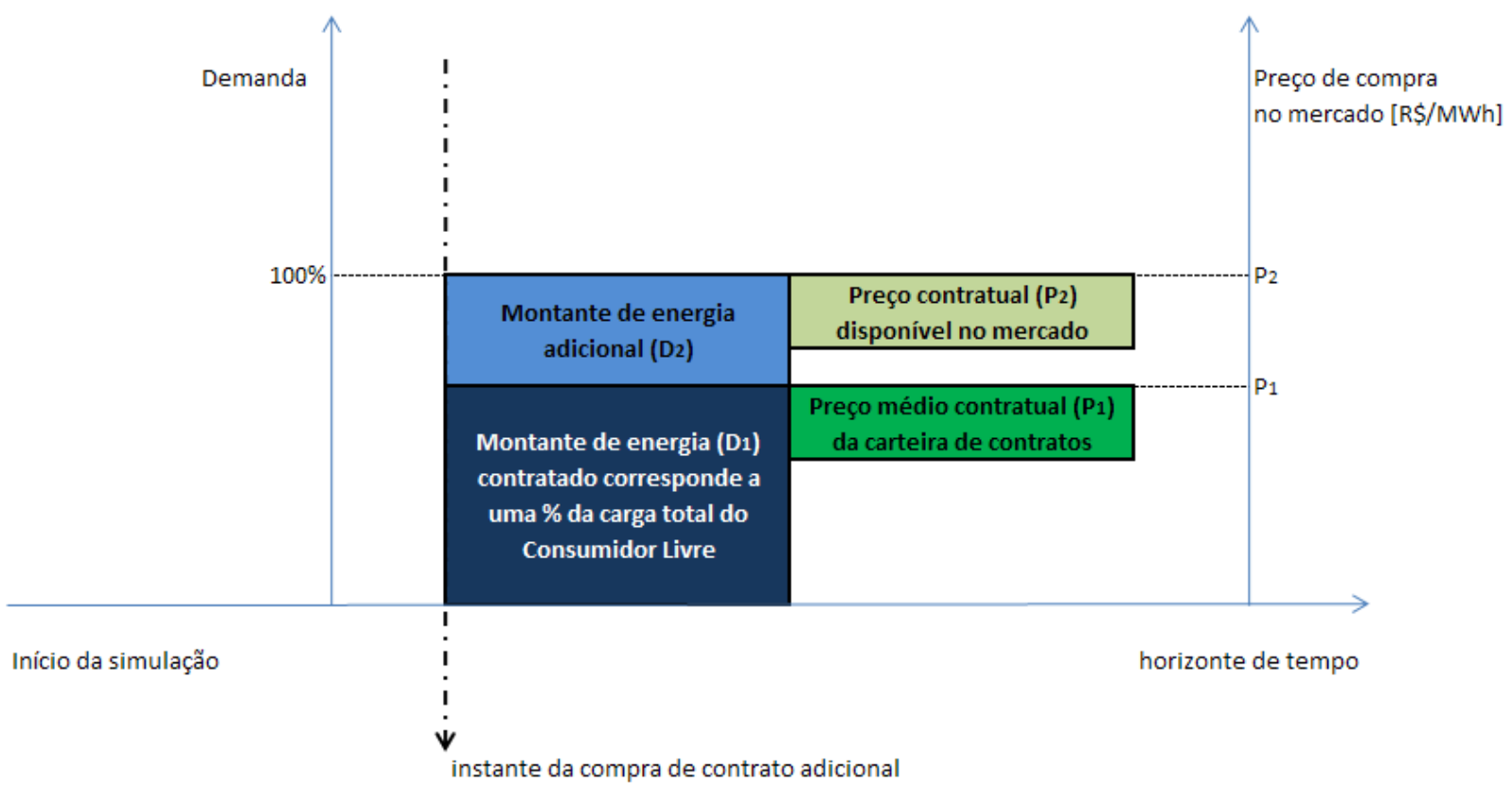

Figura 5.16 - Adicional contratual e o preço do MWmed 


\subsubsection{Definição do conceito de Value at Risk Modificado}

A definição convencional de Value at Risk, ou simplesmente VAR, refere-se a uma medida, em montante financeiro, da máxima perda de um ativo ou carteira de investimentos para um determinado horizonte de tempo e dada uma probabilidade de ocorrência (nível de confiança).

Como exemplo, a informação do VAR pode ser exposta da seguinte maneira por um gestor de um fundo de investimento: "O VAR diário do fundo de investimento $X$ é de 7\%, com nível de significância de 10\%". Ou seja, o fundo de investimento X pode ter uma perda máxima, no dia, de 7\% no seu valor, existindo a possibilidade dessa perda ser maior, mas com uma probabilidade de $10 \%$ deste evento ocorrer.

Para efeito deste trabalho, fez-se uma analogia com a definição do VAR, dispondo-se portanto do conceito aqui referenciado de VAR Modificado, VAR $\mathrm{V}_{\text {mod, }}$ através do qual é possível medir a máxima valorização ou desvalorização do preço do MWmed a ser contratado pelo Consumidor Livre, em relação ao preço de referência, Preço da Energia Nova (PEN), para o horizonte temporal de análise de 10 anos e um intervalo de confiança.

Assim sendo, o Consumidor Livre tem uma medida que informa sua exposição aos preços do MWmed em relação ao preço de referência da Energia Nova, dentro de um intervalo de confiança e um período de 10 anos de avaliação. Esta última sentença,

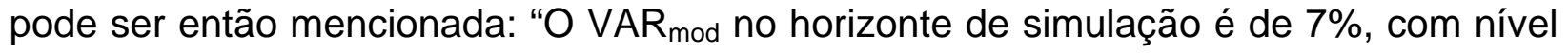
de significância de 10\%”. 
Neste caso, o preço do MWmed pode ser no máximo 7\% superior ao preço da Energia Nova, existindo a possibilidade desse valor ser maior, mas com uma probabilidade de $10 \%$ deste evento ocorrer.

\subsubsection{Definição do custo de aquisição de energia}

De modo a aferir as estratégias de contratação mais promissoras, sejam estas de curto ou longo prazos, para otimizar a aquisição de energia pelo Consumidor Livre, indica-se nesta seção as formulações utilizadas para se chegar no cálculo do custo.

Para direcionar o entendimento, o custo será apresentado em parcelas, que ao final formarão o gasto com energia totalizado ao longo dos dez anos do horizonte de análise.

- Custo mensal ( $\mathbf{C}_{\text {mensal }}$ ): é o custo incorrido em cada etapa mensal do período de simulação. Seu valor é dado pela equação (8).

$$
C_{\text {mensal }}=\sum_{c=1}^{n} P C_{c} * E C_{c}
$$

Onde:

\footnotetext{
$P C_{c} \quad$ - preço de compra do c-ésimo contrato que compõe a carteira de contratos do Consumidor Livre, $\mathrm{R} \$ / \mathrm{MWh}$;

$E C_{c} \quad$ - montante de energia comprado no c-ésimo contrato que compõe a carteira de contratos do Consumidor Livre, MWh;

c - número da ordem referente ao contrato que compõe a carteira de contratos do Consumidor Livre;

$n \quad-$ número total de contratos que compõem a carteira de contratos do Consumidor Livre, referente ao mês em questão.
} 
- Custo total ( $\mathbf{C}_{\text {total }}$ ): é o valor presente do custo incorrido ao longo dos 10 anos do período de análise. A equação (9) implementa este valor.

$$
C_{\text {total }}=\sum_{m=1}^{120}\left(\sum_{c=1}^{n} \frac{P C_{c, m} * E C_{c, m}}{(1+i)^{m-1}}\right)
$$

Onde:

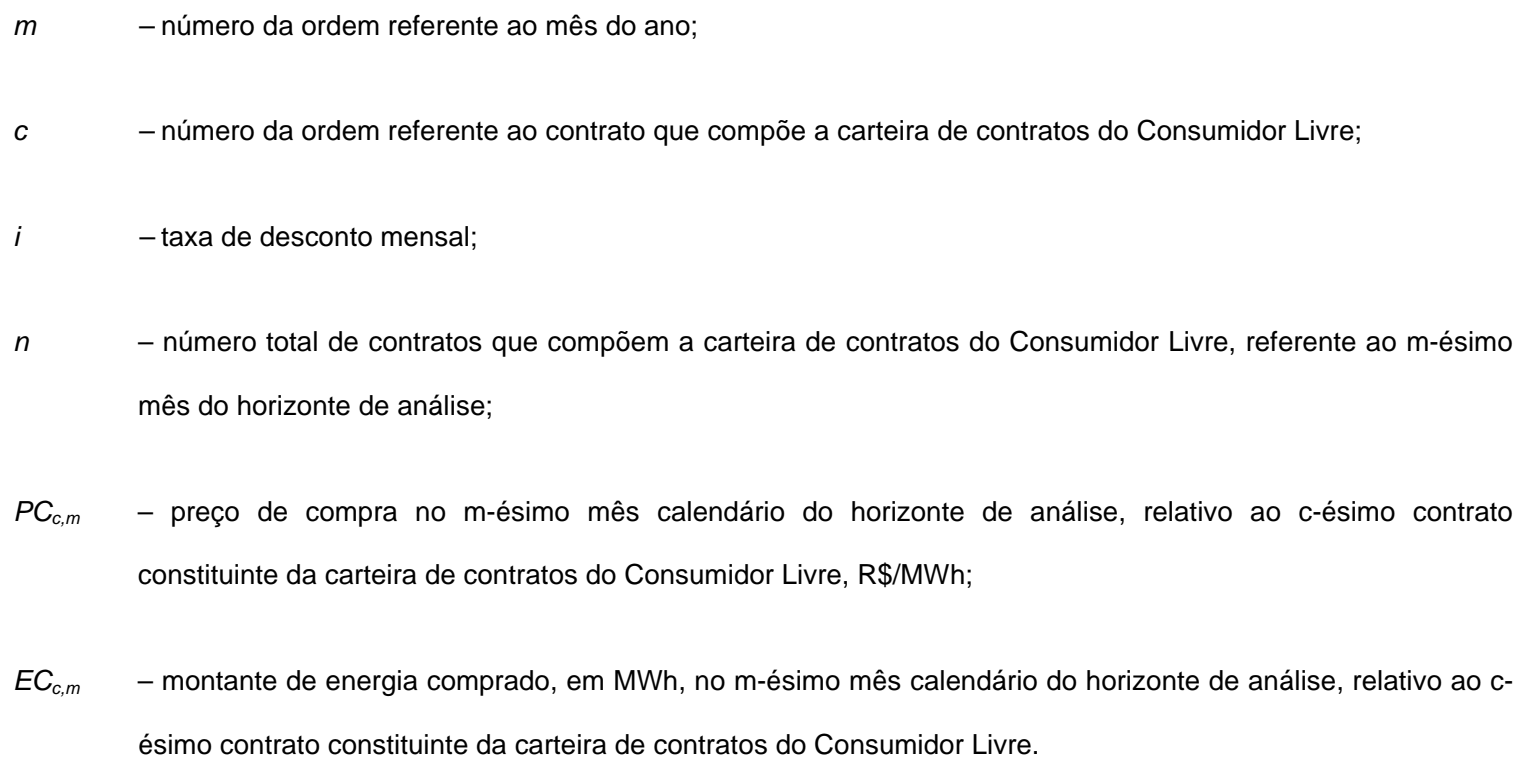

Além disso, quando é contemplada a cessão dos excedentes contratuais na composição do custo de energia, surgem porções que representam receitas no momento de calcular o balanço mensal do portfólio de contratos do Consumidor Livre.

A venda de sobras contratuais também será apresentada em parcelas, que reunidas auxiliam na definição do custo final de aquisição de energia pelo Cliente Livre.

- Receita mensal ( $\mathbf{R}_{\text {mensal }}$ ): é a receita provida em cada etapa mensal do horizonte de simulação quando existir a venda de excedentes contratuais. A formulação é dada pela equação (10). 


$$
R_{\text {mensal }}=\sum_{c=1}^{e} P V_{c} * E V_{c}
$$

Onde:

$P V_{c} \quad$ - preço de venda do c-ésimo contrato excedente que compõe a carteira de contratos do Consumidor Livre, $\mathrm{R} \$ / \mathrm{MWh}$;

$E V_{c} \quad$ - montante de energia vendida no c-ésimo contrato excedente que compõe a carteira de contratos do Consumidor Livre, MWh;

c - número da ordem referente ao contrato excedente que compõe a carteira de contratos do Consumidor Livre;

e $\quad-$ número total de contratos excedentes que compõem a carteira de contratos do Consumidor Livre, referente ao mês em questão.

- Receita total ( $\mathbf{R}_{\text {total }}$ ): é o valor presente da receita gerada ao longo dos 10 anos do período de análise com a venda de contratos excedentes. A equação (11) define este valor.

$$
R_{\text {total }}=\sum_{m=1}^{120}\left(\sum_{C=1}^{e} \frac{P V_{c, m} * E V_{c, m}}{(1+i)^{m-1}}\right)
$$

Onde:

\footnotetext{
$m \quad-$ número da ordem referente ao mês do ano;

c - número da ordem referente ao contrato excedente que compõe a carteira de contratos do Consumidor Livre;

i $\quad-$ taxa de desconto mensal;

e $\quad$ - número total de contratos excedentes que compõem a carteira de contratos do Consumidor Livre, referente ao m-ésimo mês do horizonte de análise;

$P V_{c, m} \quad$ - preço de venda no m-ésimo mês calendário do horizonte de análise, relativo ao c-ésimo contrato excedente constituinte da carteira de contratos do Consumidor Livre, $\mathrm{R} \$ / \mathrm{MWh}$;

$E V_{c, m} \quad$ - montante de energia vendida, em MWh, no m-ésimo mês calendário do horizonte de análise, relativo ao césimo contrato excedente constituinte da carteira de contratos do Consumidor Livre.
} 
Portanto o custo final, $\mathrm{C}_{\text {final, }}$, consideranto tanto os contratos de compra como os contratos de venda de energia do Consumidor Livre ao longo de todo o período de 10 anos de simulação, pode ser traduzido pela equação (12):

$$
C_{\text {final }}=C_{\text {total }}-R_{\text {total }}
$$

\subsection{PARÂMETROS DE ENTRADA}

Para emular os cenários no Ambiente de Contratação Livre apresentados neste trabalho, foram adotados alguns parâmetros de entrada balizadores da simulação. Estes dados estão separados em seções, logo a seguir, para facilitar seus entendimentos e suas respectivas referências ao longo desta dissertação.

\subsubsection{Preços spot gerados a partir do software NEWAVE}

Esta matriz de preços contém os custos marginais de operação, CMO, do Sistema Interligado Nacional.

\subsubsection{Horizonte temporal para a simulação da contratação}

Este período é igual a dez anos. Uma vez que é coincidente com as matrizes de preços extraídas do software NEWAVE.

\subsubsection{Duração dos contratos}

As modalidades contratuais implementadas nas simulações são definidas pela prazo de vigência dos contratos. Estes podem variar de um a cinco anos para cobrir o horizonte temporal de análise. 


\subsubsection{Taxa anual de atualização do capital}

A taxa de atualização do capital é de $11,75 \%$.

\subsubsection{Fator de abertura para escolha das séries de preços similares}

O valor utilizado é igual a $10 \%$. Este dado faz parte da formulação dos preços contratuais com duração superior a dois anos.

\subsubsection{Ponderação de preços para formar o segundo ano de vigência dos contratos}

Este valor pondera o preço do segundo ano de vigência dos contratos entre o preço de energia coerente com entrega em dois anos (Leilões de Energia Existente "A-1", Leilões de Ajuste e Geração Distribuída) e o preço spot. O peso atribuído é de $90 \%$ para o preço de curto prazo e o restante pondera o preço referente ao custo de expansão da oferta compatível com entrega em dois anos.

\subsubsection{Preço da Energia Nova}

O PEN ou custo unitário de projetos de geração igual a $140 \mathrm{R} \$ / \mathrm{MWh}$. Os casos específicos onde fez-se necessário a análise de sensibilidade deste parâmetro estão explícitos na apresentação dos resultados.

\subsubsection{Preço Máximo Admissível}

Os valores de PMA simulados são dois: o primeiro igual a $168 \mathrm{R} \$ / \mathrm{MWh}$ e o segundo definido como $240 \mathrm{R} \$ \mathrm{MWh}$. 


\subsubsection{Distribuição normal de probabilidade: redução do consumo de energia}

Para esta normal, adotou-se o valor de 10\% para a redução média de consumo, sendo $30 \%$ o seu desvio padrão e 500 o número de amostras da população.

\subsubsection{Distribuição normal de probabilidade: duração da redução de consumo de energia}

Para esta normal, atribuiu-se o tempo de 12 meses para a duração média da redução de consumo, com desvio padrão de 6 meses e 500 o número de amostras da população.

\subsubsection{Distribuição normal de probabilidade: tempo até a ocorrência do evento que provoca a redução de consumo de energia}

Para esta normal, definiu-se o tempo de 9 meses para representar o atraso médio para a ocorrência de um evento de redução de consumo, sendo 3 meses o seu desvio padrão e, igualmente, 500 caracteriza o número de amostras da população.

\subsubsection{Margem de comercialização}

Este parâmetro define o valor do ágio a ser aplicado nos preços formulados nas modalidades contratuais no momento de sua negociação. A margem é de $10 \%$.

\subsubsection{Energia consumida pelo Consumidor Livre}

A carga do Consumidor Livre foi assumida como sendo o valor unitário de $1 \mathrm{MWh}$.

\subsubsection{Limites de cessão dos excedentes contratuais}

As quantidades de energia admissíveis para a venda na forma de sobras contratuais, dependem da duração dos contratos que originaram os excedentes. 
Posto desta maneira, os limites estão baseados na Portaria MME №73, que sinaliza as seguintes porcentagens para as diferentes validades contratuais:

- Até $10 \%$ da energia contratada para contratos de menos de 2 anos;

- Até $20 \%$ para contratos entre 2 e 5 anos;

- Até 50\% para contratos de 5 a 10 anos.

\subsubsection{Intervalo de confiança (IC)}

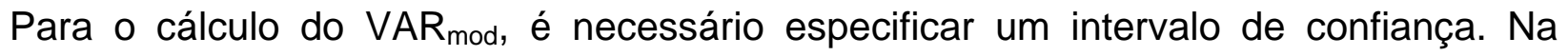
simulação foi adotado o valor de $10 \%$.

\subsubsection{Intervalo de precisão (IP)}

Adicionalmente, para o cálculo do $V_{A R}$ mod, impôs-se o intervalo correspondente a 0,1 $\mathrm{R} \$ / M W h$ para diferenciar e classificar os preços contratuais em um histograma de porcentagens acumuladas.

\subsubsection{Número de perfis de carga do Consumidor Livre (M)}

Este parâmetro define quantos perfis de consumo serão simulados. Por exemplo, se este valor for configurado como um, os valores médios calculados para os resultados refletem as estatísticas ao longo do período de 10 anos de simulação e um único cenário de perfil de carga do Consumidor Livre neste período. Neste trabalho, $\mathrm{N}$ vale 500. Ou seja, temos associados ao horizonte temporal de 10 anos, 500 diferentes cenários de perfil de consumo do Cliente Livre para caracterizar este período. 


\section{RESULTADOS OBTIDOS NAS SIMULAÇÕES}

$\mathrm{Na}$ apresentação dos resultados decidiu-se por disponibilizar as análises na sequência descrita abaixo:

- Os preços em cada tipo de contratação e os riscos de preços nestas modalidades contratuais;

- Além dos pontos levantados no item anterior, sobrepõe-se o efeito da venda de excedentes nas distintas modalidades contratuais, calcula-se o custo de aquisição de energia nestas modalidades e afere-se, também, os riscos de preços através do parâmetro de $\mathrm{VAR}_{\mathrm{mod}}$.

Uma característica a ser ressaltada é a de que a análise é feita considerando-se o comportamento médio das variáveis (custo final $-C_{\text {final, }}$ preço médio máximo - PMM, risco médio - $\mathrm{RM}$, value at risk modificado - $\mathrm{VAR}_{\text {mod }}$ ) durante o horizonte temporal de 10 anos de simulação, associando um perfil de carga do Consumidor Livre neste período. De modo a não fixar o estudo a um único perfil de carga do consumidor, realiza-se um processo iterativo para calcular o valor médio destas variáveis citadas anteriormente, mas levando-se em conta 500 realizações de cenários de perfil de consumo do Cliente Livre no período de 10 anos.

\subsection{OS PREÇOS CONTRATUAIS E SEUS RISCOS}

\subsubsection{Cenário Favorável}

Neste cenário são implementadas a previsão de crescimento da demanda energética e a expansão do fornecimento de energia elétrica previstos pelo Governo Federal para 
um período de 10 anos a partir de 2011. Para esta situação, o histograma das faixas de preços é apresentado no Gráfico 6.1.

Para complementar as informações do Gráfico 6.1, os índices no eixo das abcissas utilizam às faixas de preços correspondentes da Tabela 6.1. De acordo com o histograma disponível no Gráfico 6.1, aproximadamente $85 \%$ dos preços spot estão na menor faixa de valores possíveis, entre 20 e 78 R $\$ / M W h$. No Gráfico 6.2, são apresentados os preços médios das modalidades contratuais ao longo do período de 10 anos simulado. Observa-se a volatilidade dos preços nos contratos de 1 e 2 anos de duração, uma vez que estes são induzidos pela condição hidrológica vigente no instante da renovação contratual. Além disso, constata-se um maior valor médio dos contratos de longa duração, indicando a percepção dos preços futuros pela ponderação do valor da energia nova (PEN), sendo menos influenciado pela hidrologia predominante no instante da recontratação.

Para contrastar o comportamento do risco entre os contratos de curto e longo prazos, gerou-se os gráficos de risco ao longo do período, apresentados nos Gráficos 6.3 e 6.4.

Nota-se que, para os contratos de 5 anos de duração, o aumento do Preço Máximo Admissível (PMA) diminui o risco de exposição financeira do Consumidor Livre, como expresso no Gráfico 6.4.

O Gráfico 6.5 apresenta a curva de sensibilidade dos riscos médios em função do PMA para as cinco modalidades contratuais. Além da curva de sensibilidade, é interessante indicar também o histograma das faixas de preços dos contratos nas diferentes modalidades de aquisição de energia, conforme o Gráfico 6.6. 


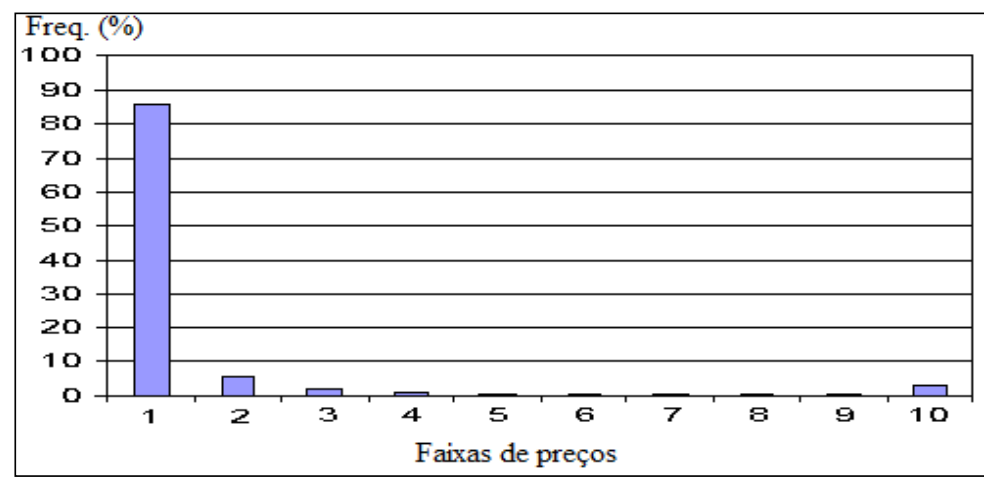

Gráfico 6.1 - Histograma das faixas de preços presentes no Cenário Favorável

Tabela 6.1 - Valores correspondentes as faixas de preços das abcissas

\begin{tabular}{|c|c|c|c|c|c|c|c|c|c|c|}
\hline Faixas & $\mathbf{1}$ & $\mathbf{2}$ & $\mathbf{3}$ & $\mathbf{4}$ & $\mathbf{5}$ & $\mathbf{6}$ & $\mathbf{7}$ & $\mathbf{8}$ & $\mathbf{9}$ & $\mathbf{1 0}$ \\
\hline Preços & $20-78$ & $78-136$ & $136-194$ & $194-252$ & $252-310$ & $310-368$ & $368-426$ & $426-484$ & $484-542$ & $542-600$ \\
(R\$/MWh) & & & & & & & & & & \\
\hline
\end{tabular}

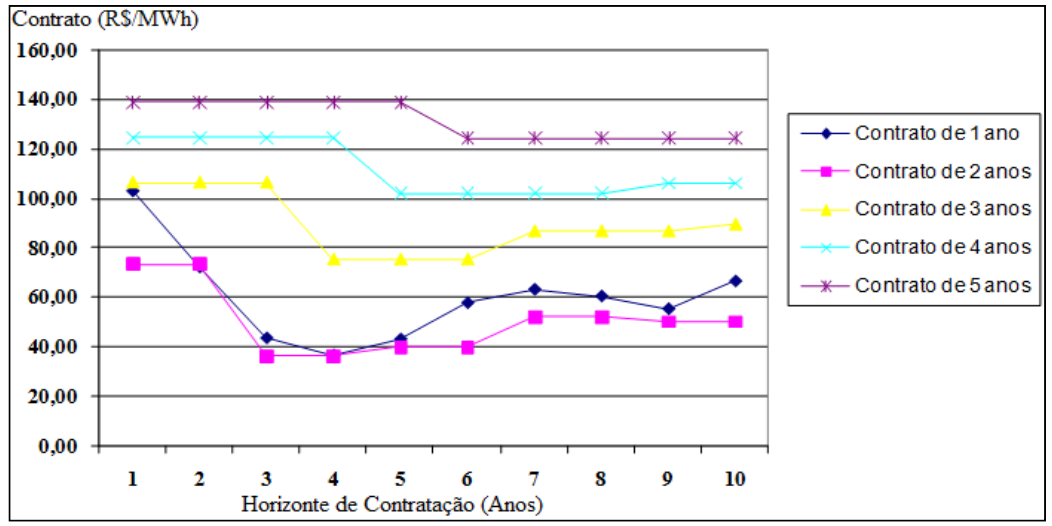

Gráfico 6.2 - Preços Médios nas distintas modalidades contratuais - Cenário Favorável 


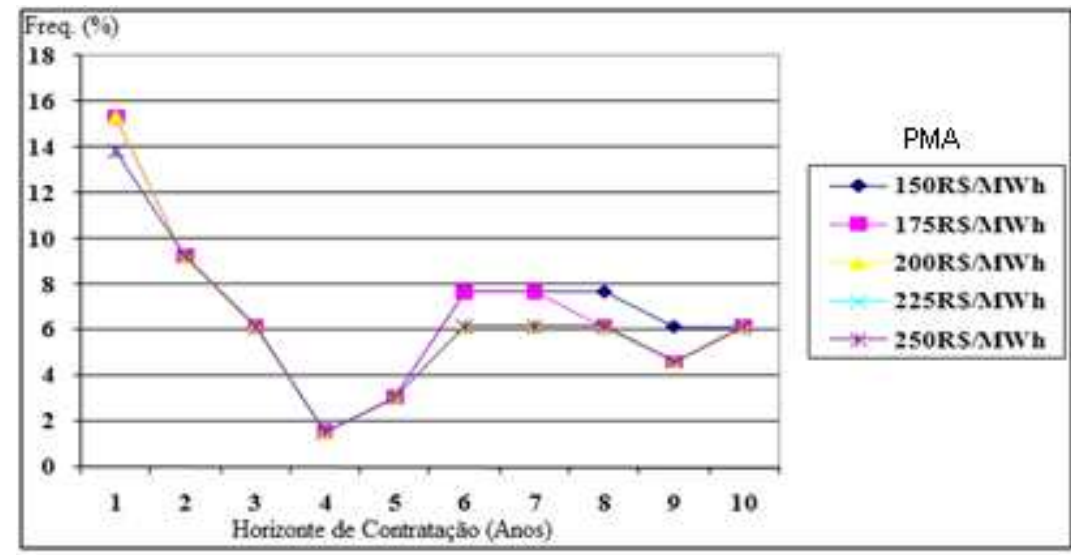

Gráfico 6.3 - Comportamento do risco ao longo do período para os contratos com um ano de duração e, variando-se o Preço Máximo Admissível (PMA) - Cenário Favorável

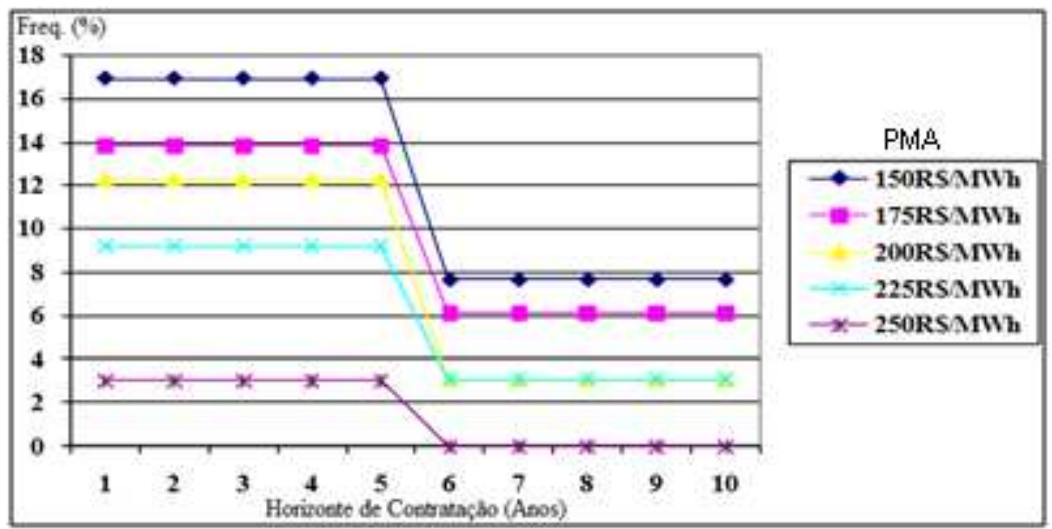

Gráfico 6.4 - Comportamento do risco ao longo do período para os contratos com cinco anos de duração e, variando-se o Preço Máximo Admissível (PMA) - Cenário Favorável

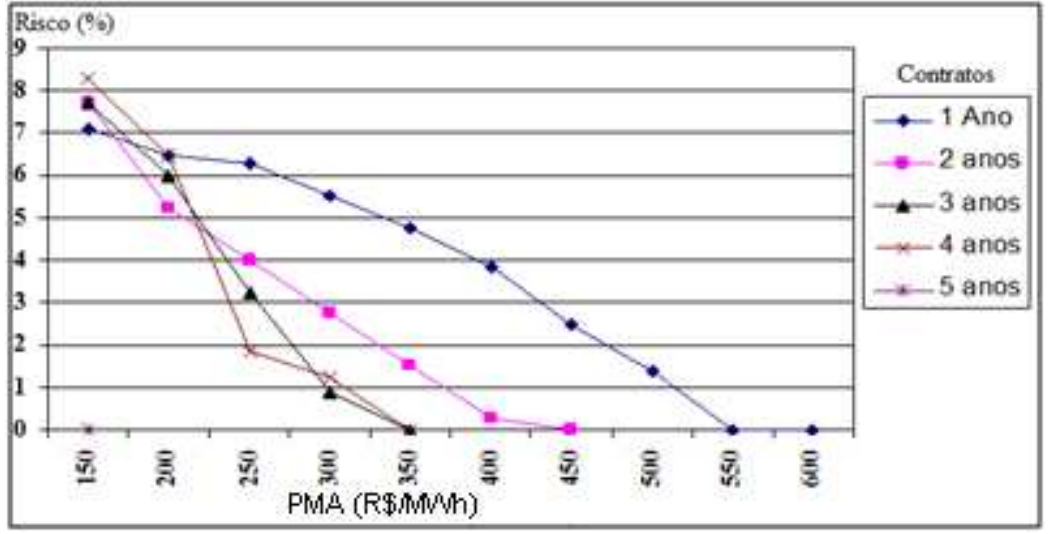

Gráfico 6.5 - Sensibilidade do risco dos contratos com a variação do Preço Máximo Admissível (PMA) - Cenário Favorável 


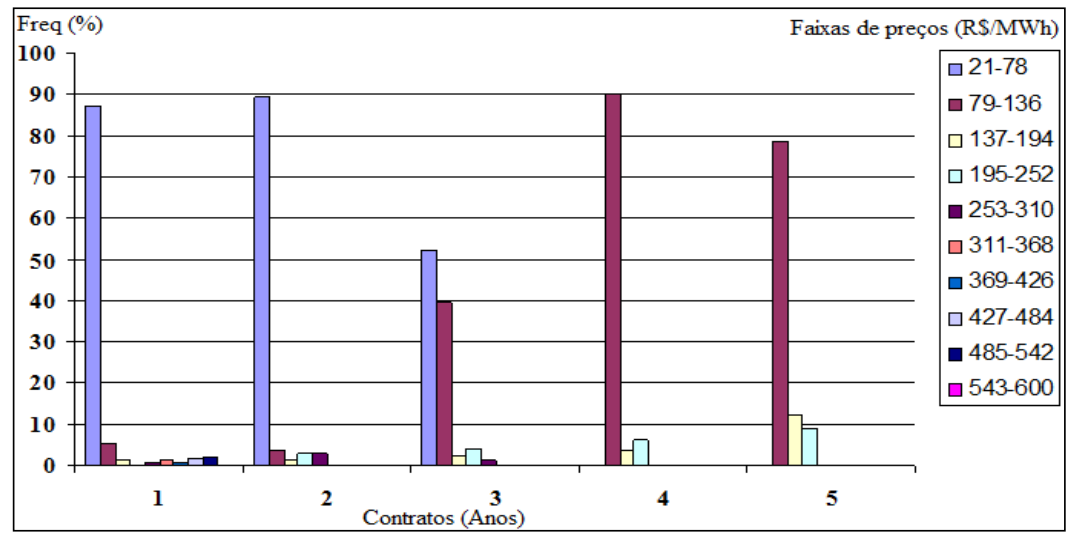

Gráfico 6.6 - Histogramas das faixas de preços possíveis em cada modalidade contratual - Cenário Favorável

Pela análise dos resultados, identifica-se, nos contratos com 1 ano de vigência, a existência de valores contratuais ocorrendo, praticamente, em todas as faixas de preços definidas no histograma. Por isso, a menor sensibilidade do risco à variação do PMA nesta modalidade contratual, conforme o Gráfico 6.6.

Em contrapartida, nos contratos longos, com duração entre 4 e 5 anos, o histograma exibe apenas algumas faixas de preços possíveis. Por conseguinte, a sensibilidade do risco nestes contratos é maior ao variar o PMA. Outro aspecto importante é que apesar dos contratos curtos possuírem a maior parte dos valores, aproximadamente $90 \%$, na menor faixa de preços, o Consumidor Livre está exposto a todas as faixas de preços contratuais. Novamente, este comportamento é evidenciado pela menor sensibilidade do risco ao PMA nos contratos de curto prazo. 
O histograma dos contratos de longo prazo, com 3 a 5 anos de duração, mostra que os valores contratuais tendem a se concentrar próximos do Preço da Energia Nova (140 $\mathrm{R} \$ / \mathrm{MWh}$ ), como indicado no Gráfico 6.6.

Portanto, para caracterizar o comportamento desses contratos, foram gerados os gráficos das faixas de preços para dois tipos de contratos, com 3 e 5 anos de duração, de acordo com o Gráfico 6.7 e o Gráfico 6.8, respectivamente.

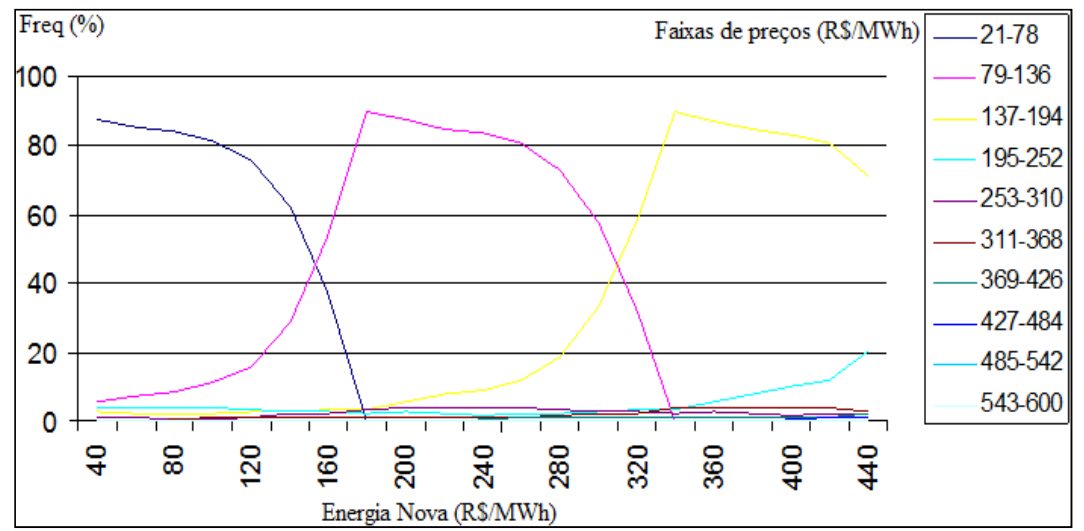

Gráfico 6.7 - Contribuição das faixas de preços nos contratos de 3 anos com a variação do valor da Energia Nova - Cenário Favorável

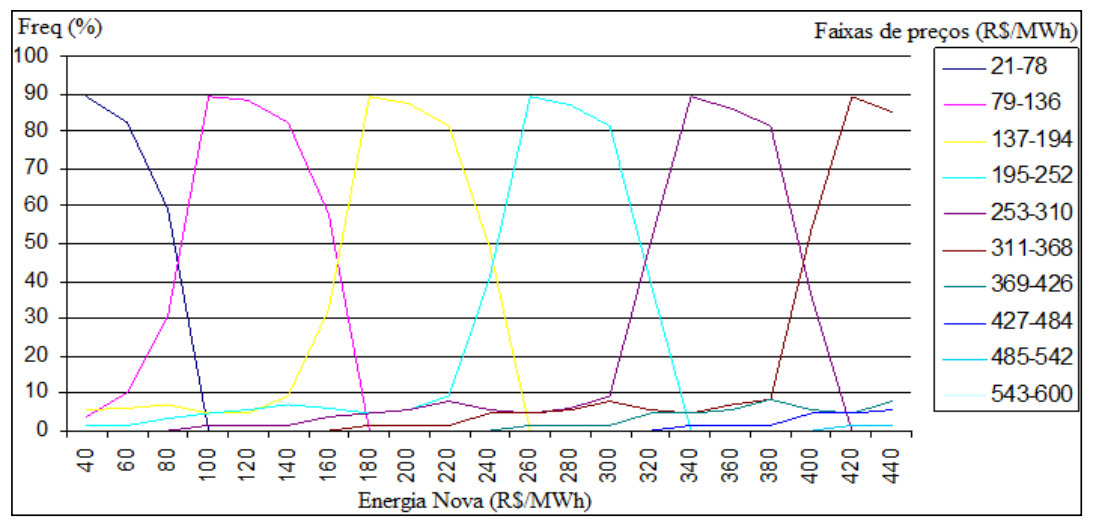

Gráfico 6.8 - Contribuição das faixas de preços nos contratos de 5 anos com a variação do valor da Energia Nova - Cenário Favorável 
Os gráficos indicam a evolução das contribuições de cada faixa de preço a partir do aumento do valor da Energia Nova, onde pode-se observar que quanto maior a duração dos contratos, a faixa de preços em torno da Energia Nova é preponderante. Ou seja, o valor dos contratos está pouco distribuído nas faixas de preços possíveis, concentrando-se em sua maioria ao redor do preço da Energia Nova. Este fato é constatado pela maior influência do custo futuro da energia, novos projetos de geração, do que das condições hidrológicas vigentes na formulação dos preços de renovação contratual.

\subsubsection{Cenário Escassez}

Ao contrário do Cenário Favorável, este ambiente projeta uma situação de escassez na oferta de energia e, conseqüente inflação nos preços de liquidação dos contratos praticados no Mercado de Curto Prazo. Na sua formulação, assumiu-se como premissa taxas de crescimento de mercado mais agressivas do que no Cenário Favorável, conjugando-se com o atraso de alguns projetos de geração preconizados no cenário favorável.

A restrição imposta à disponibilidade energética, nesta simulação, é reflexo das seguintes imposições: atraso no funcionamento das usinas hidrelétricas do Rio Madeira

e Belo Monte e, indisponibilidade de operação das usinas termelétricas afetadas pelo Termo de Compromisso da Petrobras. O resumo dessa conjuntura é descrito na Tabela 6.2. De forma semelhante à exposta para o Cenário Favorável, neste panorama são apresentados os gráficos para a comparação dos resultados obtidos entre os acordos firmados objetivando o curto e o longo prazos. 
O histograma dos preços spot é exibido no Gráfico 6.9. As faixas de preços são as mesmas definidas na Tabela 6.1. Os preços médios das distintas modalidades contratuais deste cenário é disponibilizado no Gráfico 6.10.

Como a condição imposta para esse cenário objetivou emular um sistema estressado do ponto de vista da oferta de energia, o reflexo é visto nos preço médios dos contratos, onde para todas as modalidades contratuais foram obtidos valores médios acima de $100 \mathrm{R} \$ / \mathrm{MWh}$.

Tabela 6.2 - Considerações sobre a expansão da oferta de energia para o Cenário Escassez

\begin{tabular}{|l|l|}
\hline \multicolumn{1}{|c|}{ Eventos } & \multicolumn{1}{|c|}{ Influência na oferta de energia } \\
\hline Leilão A-3 e de fontes alternativas & Considerado na formação do PLD \\
\hline Termo de compromisso da Petrobras & Considerado na formação do PLD \\
\hline Usina Rio Madeira (Abril de 2012) & Atraso no início do funcionamento \\
\hline Usina Belo Monte (Janeiro de 2014) & Atraso no início do funcionamento \\
\hline
\end{tabular}

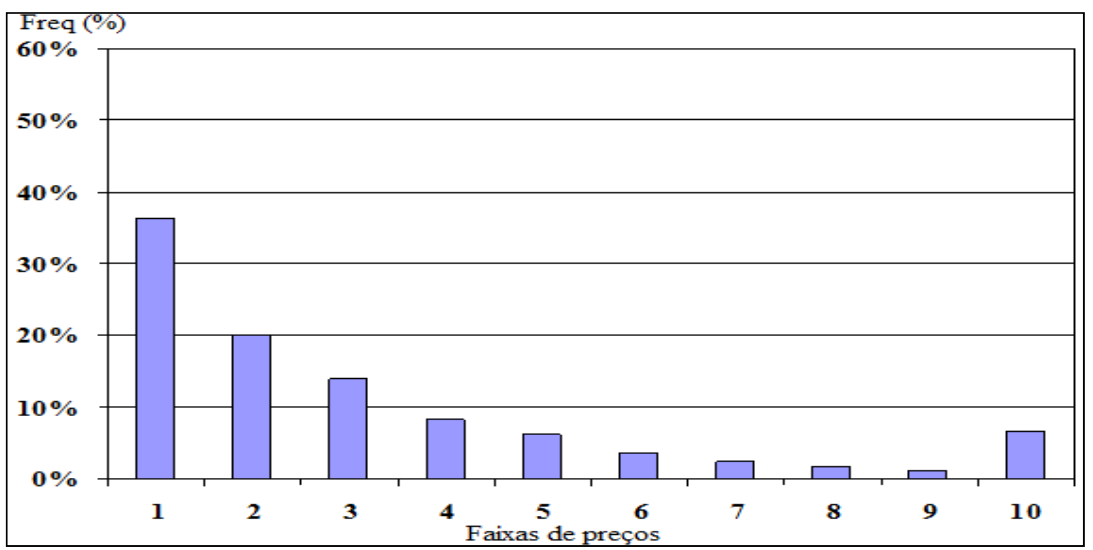

Gráfico 6.9 - Histograma das faixas de preços para o Cenário Escassez 
O comportamento dos riscos em função do Preço Máximo Admissível (PMA) para os contratos de curto e longo prazos estão dispostos no Gráfico 6.11 e no Gráfico 6.12, respectivamente. De acordo com o PMA definido nos contratos de longo prazo, os riscos podem sofrer grandes variações, aproximadamente $50 \%$ de oscilação.

Já nos contratos de curto prazo, esta alteração brusca do risco para diferentes valores de PMA não é constatada, uma vez que nos contratos de curta duração a sensibilidade do risco é menor, como pode ser verificado no Gráfico 6.13. Desse gráfico, conclui-se que o incremento no PMA provoca uma variação mais acentuada nos contratos de longo prazo do que nos contratos de menor vigência.

Além disso, com um valor equivalente a $250 \mathrm{R} \$ / \mathrm{MWh}$ para o PMA, há uma inversão no comportamento dos riscos nas modalidades contratuais disponibilizadas, posto que os contratos longos passam a proporcionar riscos menores quando comparados aos contratos de curta duração. Novamente, é importante destacar o histograma de preços para as cinco modalidades contratuais, de acordo com o Gráfico 6.14. Nota-se que à medida que o período de contratação aumenta, os valores dos contratos tendem a se concentrar entre as faixas de 79-136 R\$/MWh e 137-194 R\$/MWh, devido à influência do Preço da Energia Nova ponderado nos contratos.

O Cenário Escassez simulado, também indica a presença de mais faixas de preços de contratos nas suas diversas modalidades, diferente do exposto no Cenário Favorável. De fato, neste último, a condição mais favorável para o balanço estrutural do sistema limitou a variabilidade da faixa de preços para as diferentes modalidades contratuais, ou seja, o valor encontrado no mercado de curto prazo era predominantemente baixo. 
Do histograma, Gráfico 6.14, também se constata, que mesmo para os contratos longos, com 3 a 5 cinco anos de duração, existem no mínimo cinco faixas de preços possíveis para a contratação.

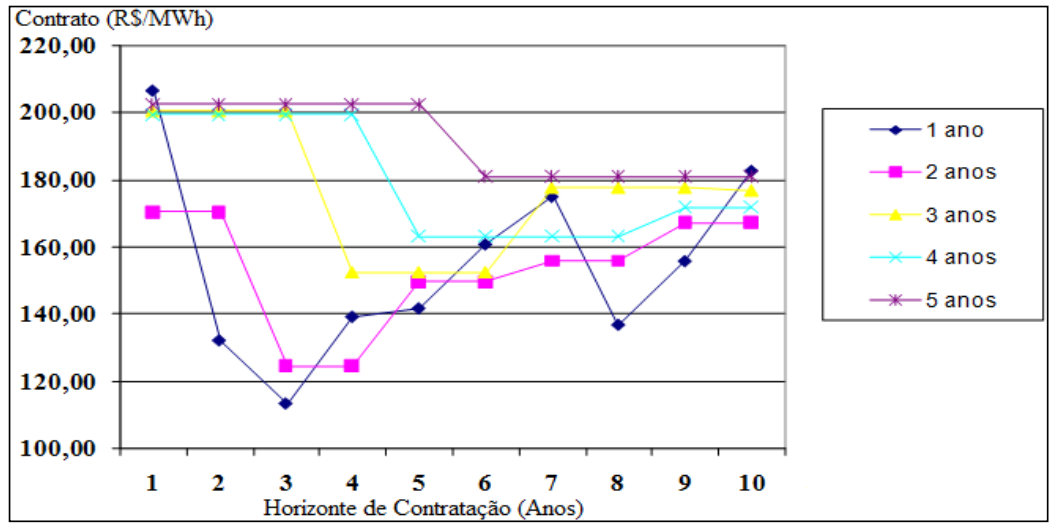

Gráfico 6.10 - Preços Médios nas distintas modalidades contratuais - Cenário Escassez

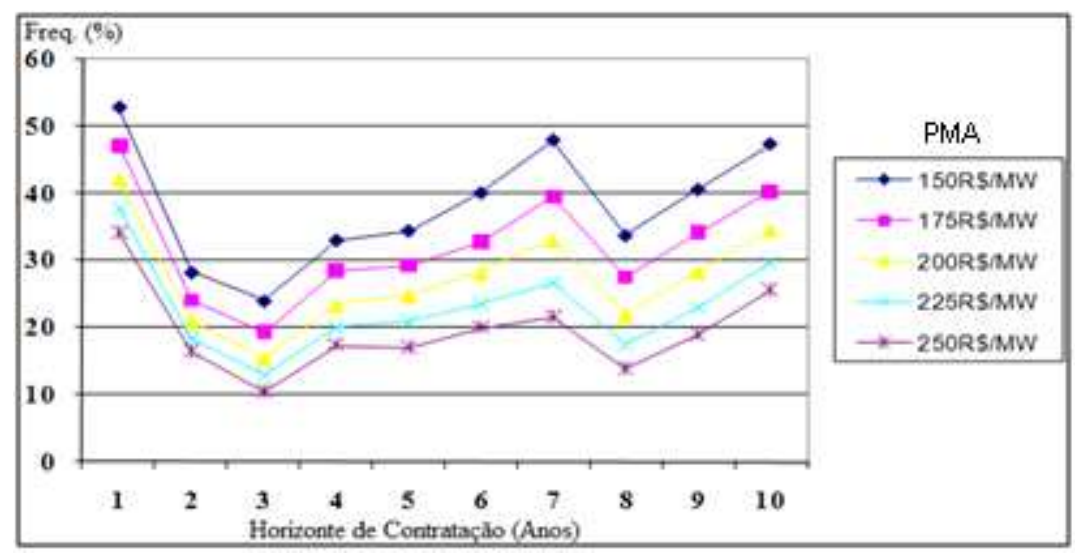

Gráfico 6.11 - Comportamento do risco ao longo do período para os contratos com um ano de duração e, variando-se o Preço Máximo Admissível (PMA) - Cenário Escassez 


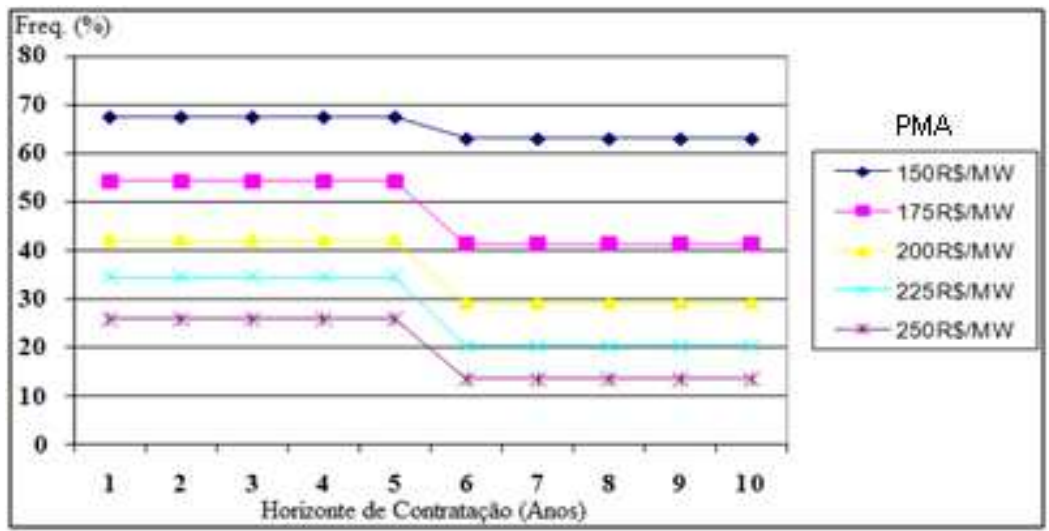

Gráfico 6.12 - Comportamento do risco ao longo do período para os contratos com cinco anos de duração e, variando-se o Preço Máximo Admissível (PMA) - Cenário Escassez

Com base nas faixas de valores obtidas para cada tipo de contrato, é possível verificar que o aumento no tempo de vigência contratual, exime o consumidor da exposição a faixas extremas de preços nos momentos de renovação contratual. Assim, são indicados no Gráfico 6.15 e no Gráfico 6.16, o comportamento das faixas de preços nas modalidades contratuais de longo prazo quando alterado o Preço da Energia Nova (PEN).

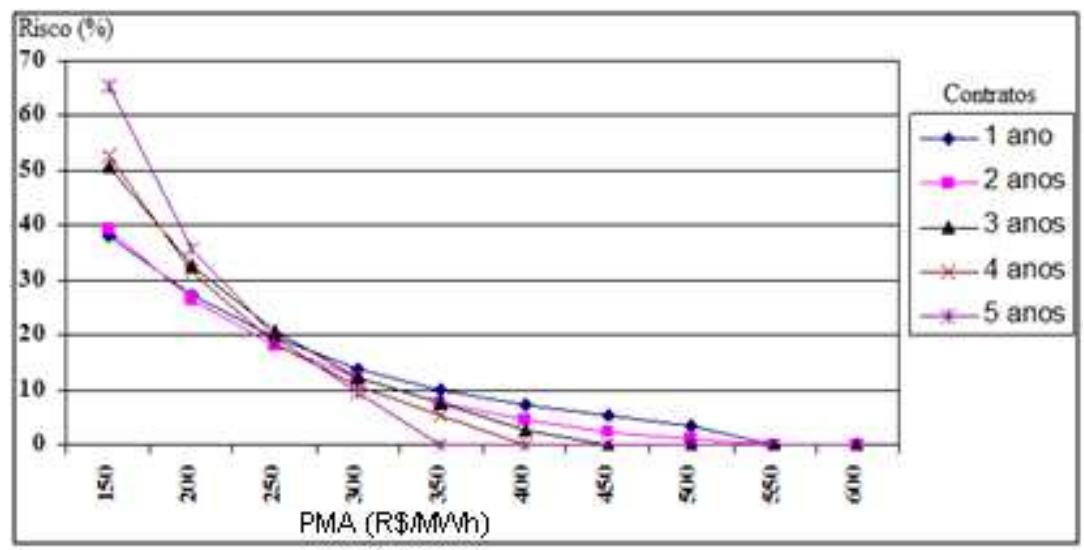

Gráfico 6.13 - Sensibilidade do risco dos contratos com a variação do Preço Máximo Admissível (PMA) - Cenário Escassez 


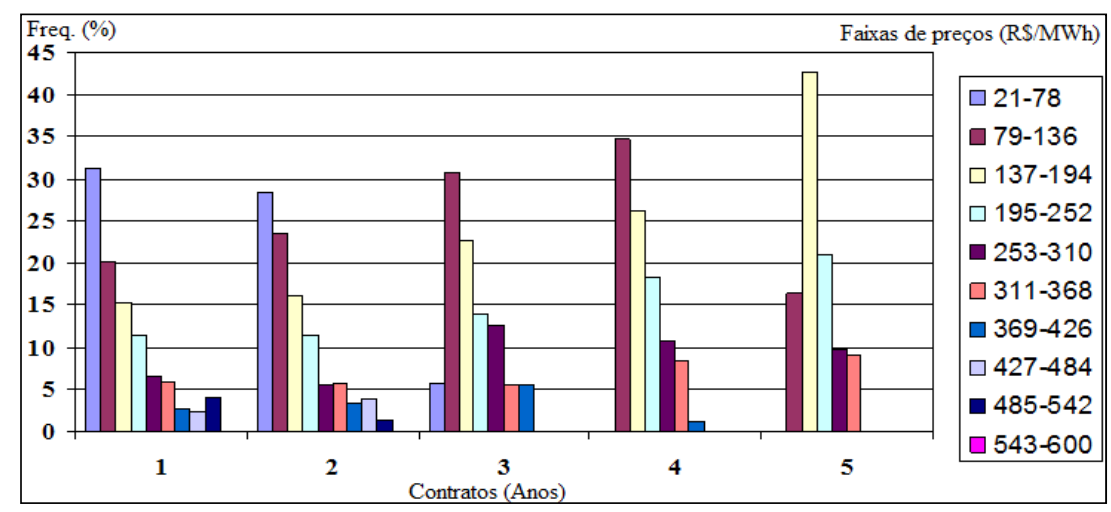

Gráfico 6.14 - Histogramas das faixas de preços possíveis em cada modalidade contratual - Cenário Escassez

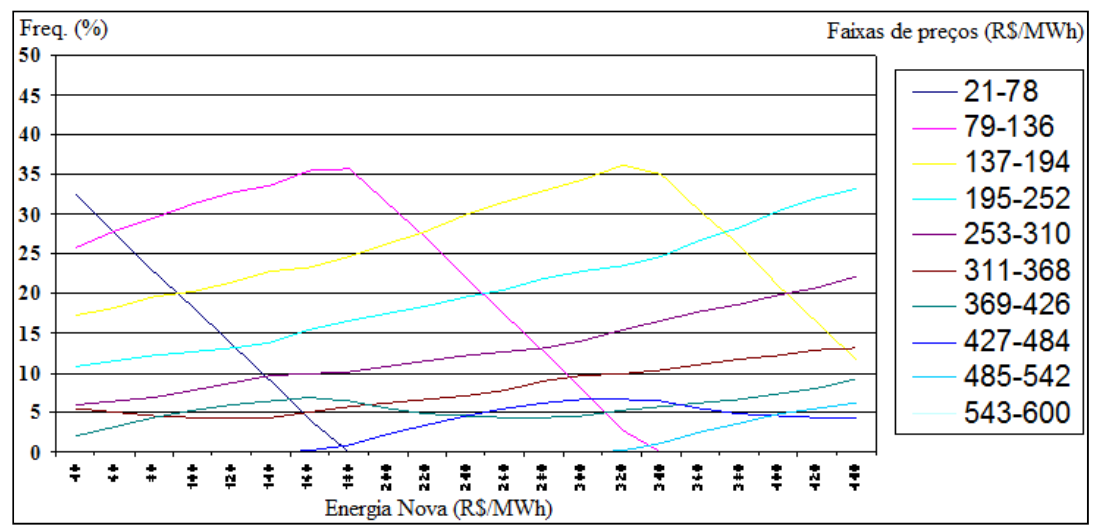

Gráfico 6.15 - Contribuição das faixas de preços nos contratos de 3 anos com a variação do valor da Energia Nova - Cenário Escassez

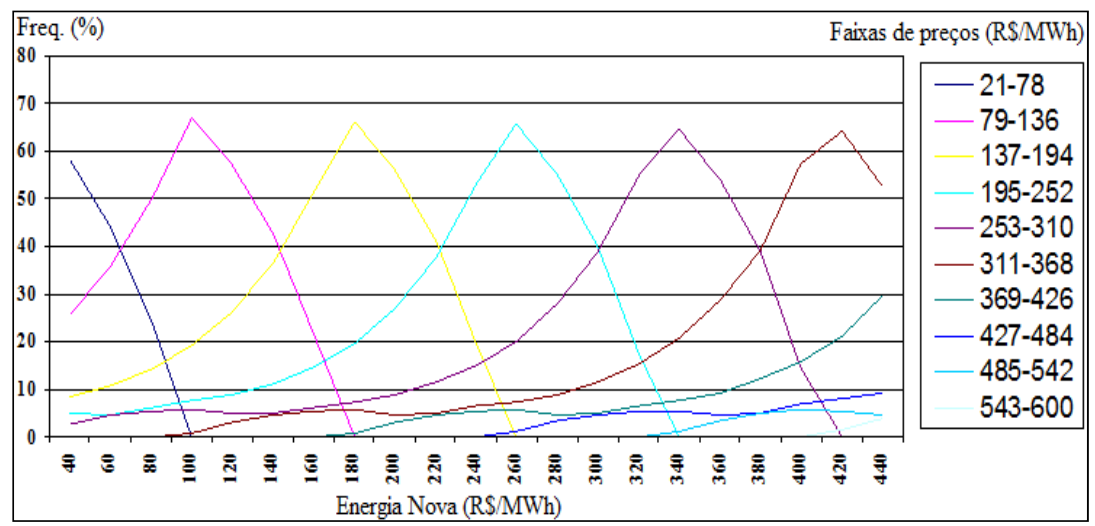

Gráfico 6.16 - Contribuição das faixas de preços nos contratos de 5 anos com a variação do valor da Energia Nova - Cenário Escassez 
O Gráfico 6.15 e o Gráfico 6.16 reforçam também, no Cenário Escassez, que o aumento no tempo de vigência dos contratos, desloca a faixa de preços predominante para valores próximos do Preço da Energia Nova estipulado na simulação.

\subsection{O EFEITO DA CESSÃO DOS EXCEDENTES CONTRATUAIS}

\subsubsection{Cenário Favorável}

De forma semelhante à análise empregada na seção 6.1, onde, para avaliar o nível de preços médios encontrados em cada modalidade contratual e associar os respectivos riscos de exposição a preços, considerou-se dois cenários de projeção de preços no mercado de curto prazo e de oferta de energia disponível no SIN, o estudo do efeito da cessão dos excedentes contratuais também avaliará os resultados submetidos aos cenários preconizados anteriormente. Para tanto, inicia-se pela apresentação dos resultados para o cenário favorável, no qual a projeção de preços no mercado de curto prazo é tida como otimista, ou seja, os seus valores são, em média, bastante baixos.

À medida que avançaram as simulações, novos aspectos visando captar o comportamento do agente Consumidor Livre, foram incorporadas ao modelo. Assim, uma primeira análise simulou a venda de excedentes contratuais sempre pelo limite admitido em cada duração contratual, de acordo os resultados exibidos na próxima seção.

\subsubsection{1.}

Cessão de excedentes pelo limite previsto na modalidade contratual

Nesta etapa do trabalho, o modelo impõe que o Consumidor Livre ceda o limite máximo admissível do seu contrato de energia. 
Assim, como exemplo, um contrato com 1 ano de duração tem a possibilidade de vender até $10 \%$ da energia contratada originalmente. No entanto, nesse caso, o modelo adotado faz o Consumidor Livre vender "sempre" pelo limite, independentemente, do valor da redução de consumo. Ou seja, se houver uma redução de consumo de $5 \%$ da carga do Consumidor Livre, este cederá compulsoriamente os $10 \%$ admitidos no seu contrato, passando a adquirir imediatamente a diferença no mercado de curto prazo ou contrato com a duração necessária para cobrir o consumo até a data de término do contrato principal.

Nos cenários reportados, são comparadas as seguintes possibilidades:

- Situação $(A)$ : sem a possibilidade da venda de excedentes contratuais;

- Situação (B): com a possibilidade da venda de excedentes e compra do montante necessário para cobrir uma retomada de consumo através de contratos curtos no mercado spot. Os detalhes desta condição estão discriminados no tópico - 5.6 A cessão dos excedentes contratuais e sua precificação;

- Situação (C): com a possibilidade da venda de excedentes e compra de retomada de consumo através de contratos de duração coincidentes com o vencimento do contrato que originou o excedente contratual. Novamente, os detalhes desta condição estão expostos no tópico - 5.6 A cessão dos excedentes contratuais e sua precificação. 
Primeiramente, é apresentado o custo final, $\mathrm{C}_{\text {final, }}$, de aquisição de energia e, depois, os Preços Médios Máximos (PMM), para um valor de entrada de $168 \mathrm{R} \$ / \mathrm{MWh}$ para o Preço Máximo Admissível (PMA). Este parâmetro define o grau de aversão à riscos de preços do Consumidor Livre.

A possibilidade da cessão de excedentes contratuais minimizou o custo de aquisição de energia quando calculado o equivalente econômico do custo considerando os dez anos do horizonte temporal de análise. Os resultados referentes ao valor presente médio nas distintas modalidades contratuais é apresentado no Gráfico 6.17.

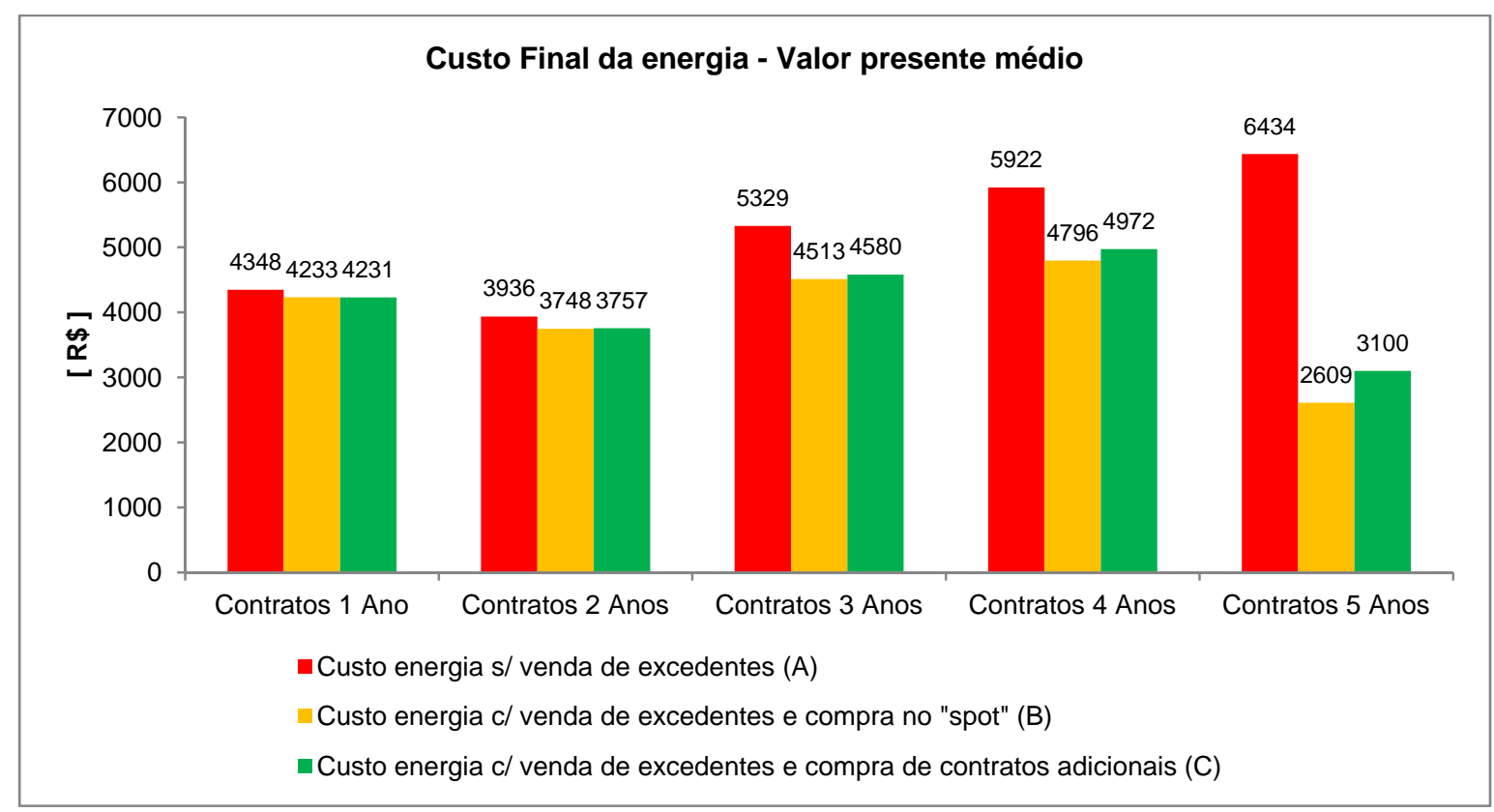

Gráfico 6.17 - Custo da energia nas distintas modalidades contratuais - Cessão pelo limite - Cenário Favorável

Na Situação (A), ou seja, sem a possibilidade da venda de excedentes contratuais, os contratos de menor vigência, um e dois anos, apresentam os menores custos quando calculado seus valores presentes líquidos. 
Para os contratos com duração de dois anos, este valor médio é de $R \$ 3936$. Em contrapartida, os contratos de maior duração, três a cinco anos, expõem o consumidor a custos mais elevados, uma vez que os preços nestas modalidades contratuais refletem não somente os valores de preços do mercado de curto prazo, mas também são ponderados pelo preço da energia responsável por expandir a oferta de geração.

$\mathrm{Na}$ Situação (B) aqui retratada, considera-se a possibilidade da venda de excedentes contratuais e, caso haja retomada de consumo pelo Cliente Livre antes do término do contrato que originou o excedente contratual, admite-se que este recorre ao mercado de curto prazo para lastrear a sua demanda energética.

Pode-se observar que nesta condição, os contratos de maior vigência tornam-se vantajosos com relação ao custo refletido no valor presente líquido. O contrato com cinco anos de duração apresenta um custo de $\mathrm{R} \$ 2609$. O menor valor de custo está relacionado a possibilidade de comercialização dos excedentes contratuais em conjunturas econômicas desfavoráveis ao Consumidor Livre, pois, nos contratos longos, os aspectos regulatórios sinalizam para limites maiores na ocorrência de sobras contratuais.

Para o caso dos contratos com duração de cinco anos, é permitida a cessão até o limite de $50 \%$ do volume originalmente contratado. E, como colocado inicialmente, numa primeira abordagem do modelo ora simulado, a cessão é sempre dada pelo limite máximo admitido no contrato. 
$\mathrm{Na}$ Situação (C), aqui caracterizada pela possibilidade de venda dos excedentes contratuais e, na eventualidade de retomada de consumo pelo Cliente Livre antes do término do contrato que originou o excedente contratual, este, diferentemente do ocorrido na Situação (B), adquire um novo contrato para lastrear sua demanda energética, porém, o contrato tem duração compreendida entre o início da retomada e o seu término coincidente com o vencimento do contrato que originou o excedente contratual. Novamente, os contratos de longa duração apresentam menor custo, porque além dos preços no mercado de curto prazo permanecerem a maior parte do tempo em valores baixos, reflexo da matriz de preços de CMO utilizadas, o Consumidor Livre tem a flexibilidade de ceder o seu contrato firmado no limite de $50 \%$ do montante acordado originalmente.

Uma outra análise a ser feita é o nível de exposição do Consumidor Livre aos preços máximos praticados em cada modalidade contratual. É importante salientar que o Preço Médio Máximo (PMM) foi calculado como um valor ponderado do preço da energia pelo MWmed a ser contratado em relação ao total de energia já lastreado pelo Consumidor Livre. Estes resultados são apresentados no Gráfico 6.18.

Como pode ser verificado, os contratos de menor vigência alcançam os maiores preços contratuais quando analisada a Situação (A), ou seja, sem a possibilidade da venda dos excedentes contratuais.

Adicionalmente, nota-se que com o aumento no tempo de duração do contrato, menores são os valores de Preço Médio Máximo aos quais o Consumidor Livre estará exposto nesta situação. 


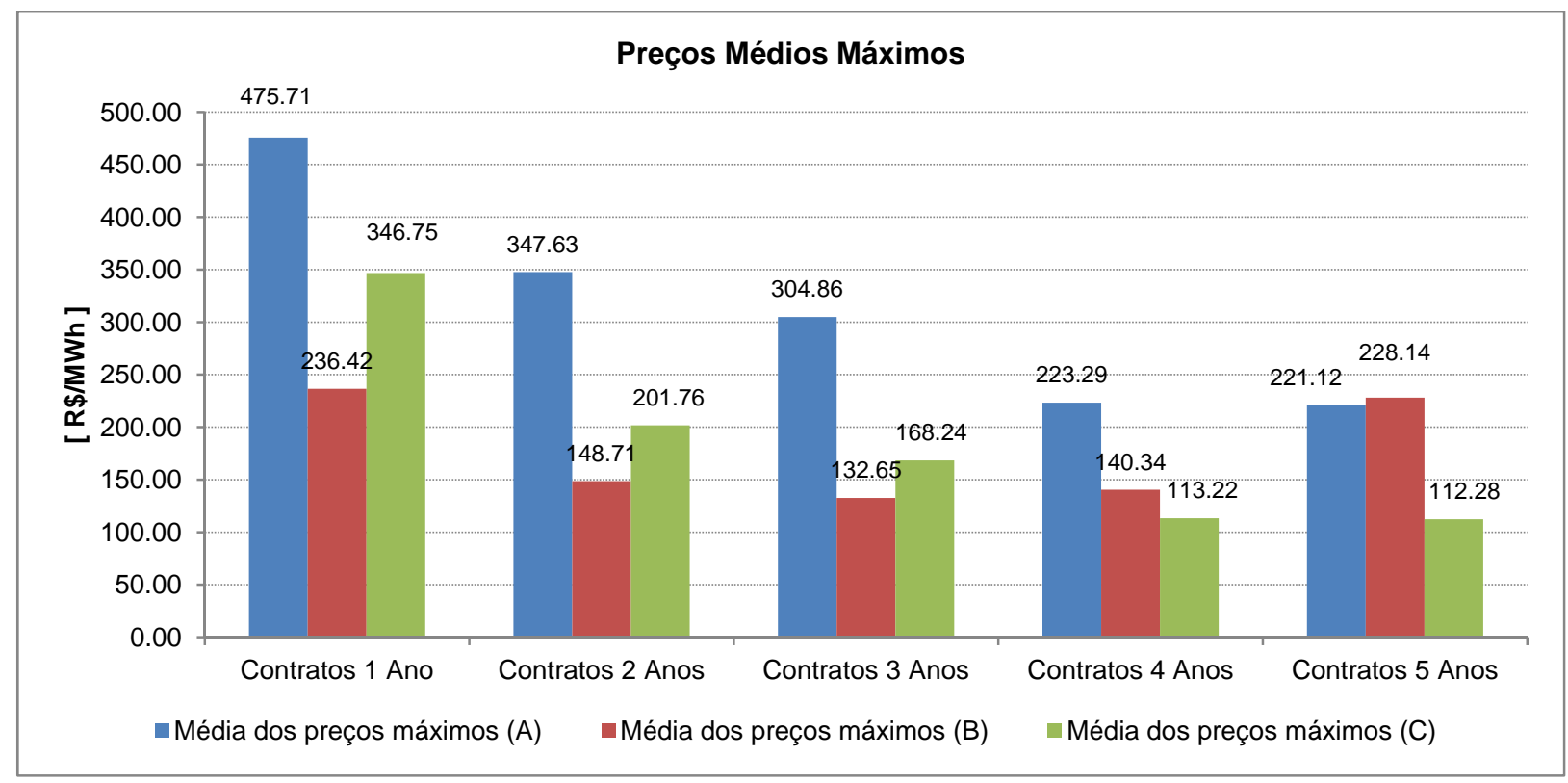

Gráfico 6.18 - Preços Médios Máximos nas distintas modalidades contratuais e para um Preço Máximo Admissível (PMA) de 168 R \$MWh - Cessão pelo limite - Cenário Favorável

Ao comparar os Preços Médios Máximos dentro de cada uma das modalidades contratuais e perfazer a análise destes valores entre as Situações $(A),(B)$ e $(C)$, podese inferir que:

- No caso (A), os Preços Médios Máximos são maiores quando comparados aos casos (B) e (C), nas modalidades contratuais de um a quatro anos. Isso porque, não havendo a possibilidade da venda de excedentes contratuais, o Consumidor Livre expõe-se aos preços de mercado somente no momento da renovação dos contratos dentro da modalidade contratual escolhida.

- No caso (B), os Preços Médios Máximos encontrados são os menores, dentro das modalidades contratuais compreendidas entre um e três anos de duração. Este comportamento reflete a ação do Consumidor Livre de recorrer um número 
menor de vezes ao mercado de curto prazo para lastrear a sua demanda energética, quando há uma retomada de seu consumo, submetendo-se portanto à preços em média menores, posto que os preços no mercado de curto prazo permanecem a maior parte do tempo em valores baixos - Cenário Favorável. Como por hipótese, na Situação (B), caso haja retomada de consumo pelo Cliente Livre antes do término do contrato que originou o excedente contratual, este recorre ao mercado de curto prazo para lastrear a sua demanda energética, como pode ser observado, nos contratos com vigência entre quatro e cinco anos, pelo fato do Cliente Livre ter que recorrer mais vezes ao mercado de curto prazo nas retomadas de consumo, expõe-se a mais recontratações e, consequentemente, o preço médio máximo encontrado nestas modalidades é superior quando comparado com os contratos de menor duração, entre um e três anos.

- No caso (C), os Preços Médios Máximos têm os valores compreendidos entre àqueles encontrados no caso $(A)$ e àqueles enfrentados no caso $(B)$, dentro das modalidades contratuais de um a três anos de duração. Isso denota a forma como o Consumidor Live está adquirindo o montante de energia para atender à sua retomada de consumo. Uma vez que este firma contratos com duração compreendida entre o início da retomada de consumo e o término coincidente com o vencimento do contrato que originou o excedente contratual, dessa maneira recorre um número menor de vezes ao mercado de curto prazo para contratar seu requisito energético e, portanto, expõe-se menos aos preços deste mercado. E, além disso, nos contratos longos, quatro e cinco anos, os acordos 
realizados para cobrir a retomada de consumo, apresentam maior duração, visto que são firmados coincidindo o início da retomada de demanda e o vencimento do contrato majoritário que esteja vigente, portanto diminuindo a exposição do Consumidor Livre aos preços praticados nas recontratações de curto prazo.

Uma ênfase especial foi dada para os resultados referentes aos riscos médios de valores acima do Preço Máximo Admissível (PMA), onde se destaca uma simulação para um valor de PMA de $168 \mathrm{R} \$ / \mathrm{MWh}$ e a outra para um valor de PMA de 240 $\mathrm{R} \$ / \mathrm{MWh}$, apresentados no Gráfico 6.19 e no Gráfico 6.20, respectivamente.

Como pode ser depreendido do Gráfico 6.19, na Situação $(A)$, sem a possibilidade da venda de excedentes, quanto maior a duração contratual, maior será o risco dos preços estarem acima do Preço Máximo Admissível (PMA), principalmente devido ao efeito do "travamento" de preço em valor elevado, por mais tempo no contrato mais longo, quando de uma renovação contratual em condição desfavorável. Na Situação (B), os riscos médios são praticamente os mesmos em todas as modalidades contratuais e, valem aproximadamente $7.65 \%$. E, na Situação (C), todos os riscos estão compreendidos no entorno de $7.5 \%$. Além disso, independente da modalidade contratual, a possibilidade de cessão dos excedentes contratuais reduz o risco dos preços contratuais figurarem na faixa de preços superior ao PMA.

Por fim, nota-se que para um valor de PMA de $240 \mathrm{R} \$ / \mathrm{MWh}$, de acordo com o Gráfico 6.20 , os valores de risco diminuem a medida em que se aumenta o tempo de duração dos contratos, exceção feita quando se compara estes valores partindo dos contratos com quatro anos e se alterna para os contratos com cinco anos de vigência. 


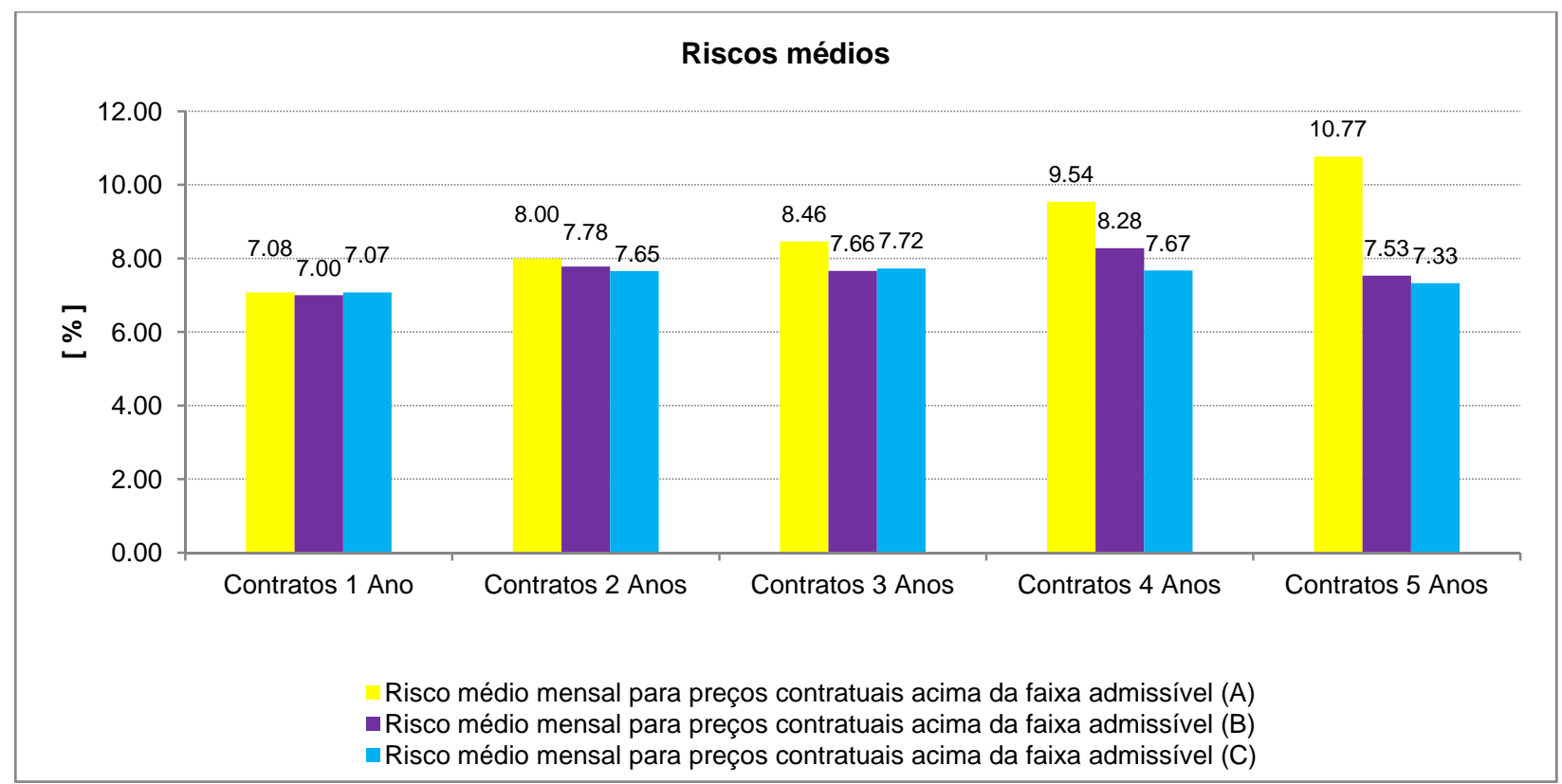

Gráfico 6.19 - Riscos médios de preços acima do PMA de 168 R\$/MWh - Cessão pelo limite Cenário Favorável

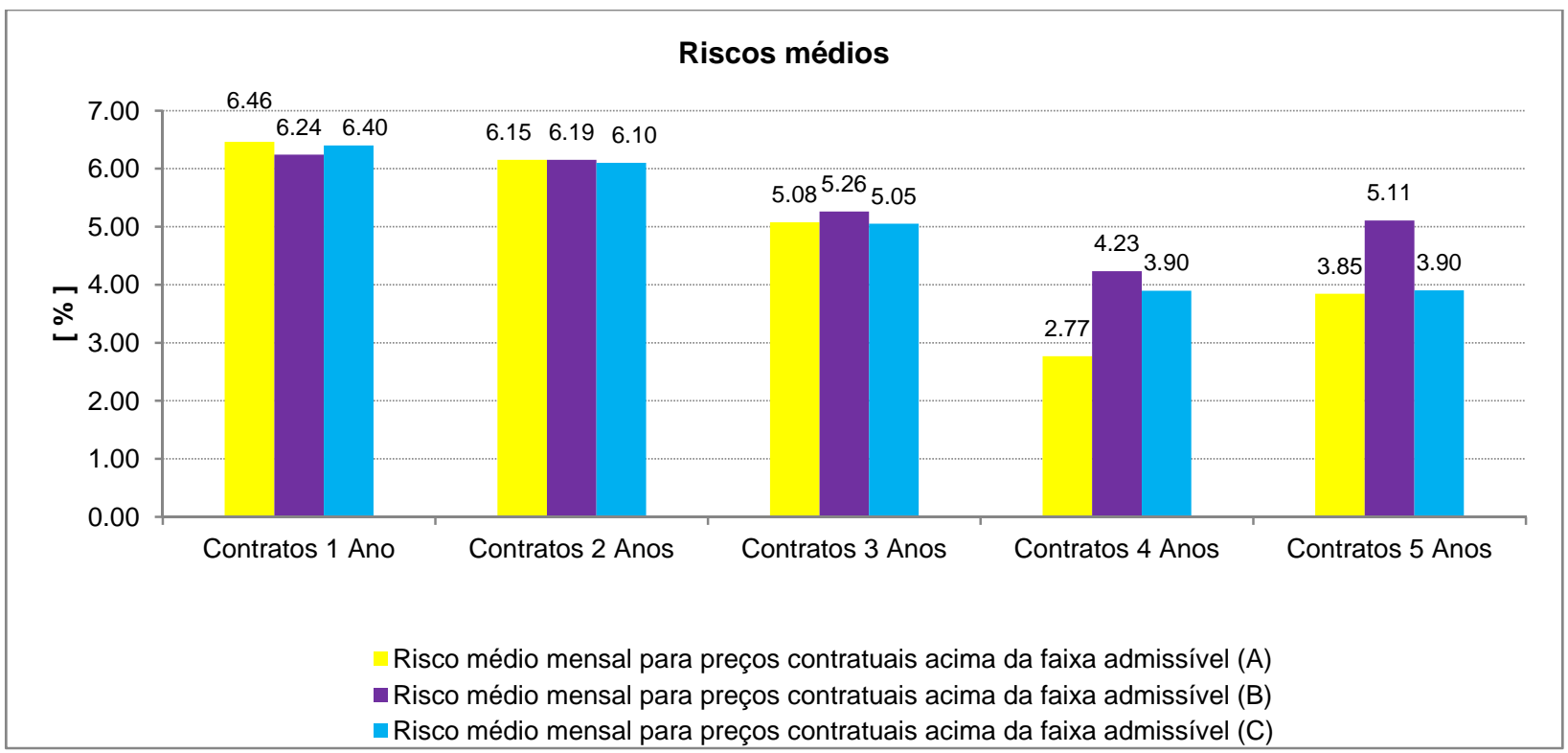

Gráfico 6.20 - Riscos médios de preços acima do PMA de 240 R\$/MWh - Cessão pelo limite Cenário Favorável 
Neste caso, o risco é maior, pois como a duração dos contratos é mais extensa, decorrem as consequências descritas a seguir, de acordo com a condição aplicada para a venda de excedentes. Na situação $(A)$, sem venda de excedentes contratuais, os contratos mais longos mitigam o risco de preços extremos, quando comparados aos contratos mais curtos, porém os contratos de 4 anos de duração configuram menor risco, em comparação aos contratos de 5 anos, porque nesses últimos acaba prevalecendo o efeito do "travamento" de preço em valor elevado nos contratos mais longos, quando o preço contratado é desfavorável no momento da renovação.

$\mathrm{Na}$ Situação (B), o Consumidor Livre recorre muitas vezes ao mercado de curto prazo para atendimento do seu requisito energético, no período de tempo compreendido entre a retomada de seu consumo e o vencimento do contrato vigente de cinco anos, portanto expondo-se aos preços de curto prazo nos eventos de recontratação, contabilizando o risco de preços acima de PMA negativamente.

Por outro lado, na Situação (C), embora idealizado um cenário favorável de preços no mercado de curto prazo, a contratação de retomada de consumo é feita coincidindo com o momento do restabelecimento de demanda e o vencimento do contrato original de cinco anos, ou seja, os prazos dos contratos de lastro, em situação de retomada de consumo, tendem a possuir durações longas.

Por conseguinte, a precificação destes contratos passa a sofrer maior influência da parcela ponderada pelo preço da energia nova (PEN), justificando valores contratuais mais elevados e, riscos de preços maiores, estes últimos penalizados por figurarem acima de PMA. 
Este fato neutraliza o efeito benéfico da menor exposição a preços de curto prazo extremados no momento da renovação, acarretando riscos praticamente iguais para contratos de 4 ou 5 anos de duração.

\subsubsection{2. $\quad$ Cessão de excedentes até o limite previsto na modalidade contratual}

Para os resultados desta seção, aprimorou-se o modelo de simulação de tal modo que a cessão dos excedentes contratuais é realizada até o limite da porcentagem permitida no contrato. Assim, como citado anteriormente, um contrato com 1 ano de duração tem a possibilidade de vender até $10 \%$ da energia contratada originalmente. Com essa nova hipótese incorporada no modelo, se houver uma redução de consumo de $5 \%$ da carga do Consumidor Livre, este cederá somente os $5 \%$ do contrato, resguardando para a venda os outros $5 \%$ para uma eventual redução de consumo que possa vir a ocorrer em um evento futuro. Novamente, dispõe-se das seguintes possibilidades:

- Situação $(A)$ : sem a possibilidade da venda de excedentes contratuais;

- Situação (B): com a possibilidade da venda de excedentes e compra de retomada de consumo através de contratos de curta duração no mercado de curto prazo. Os detalhes desta condição estão discriminados no tópico - 5.6 A cessão dos excedentes contratuais e sua precificação;

- Situação (C): com a possibilidade da venda de excedentes e compra de retomada de consumo através de contratos coincidentes com o vencimento do contrato que originou o excedente contratual. Novamente, os detalhes desta condição estão expostos no tópico - 5.6 A cessão dos excedentes contratuais e sua precificação. 
Na sequência é apresentado o custo final, $\mathrm{C}_{\text {final }}$, de aquisição de energia e os Preços Médios Máximos (PMM), para um valor de entrada de 168 R $\$ / M W h$ para o Preço Máximo Admissível (PMA).

A possibilidade da cessão de excedentes contratuais, baseando-se tanto na Situação (B) como na Situação $(C)$, minimizou o custo final de aquisição de energia para todas as modalidades contratuais quando calculado o equivalente econômico do custo considerando os dez anos do horizonte temporal de análise. Os resultados referentes ao valor presente médio nas distintas modalidades contratuais é apresentado no Gráfico 6.21.

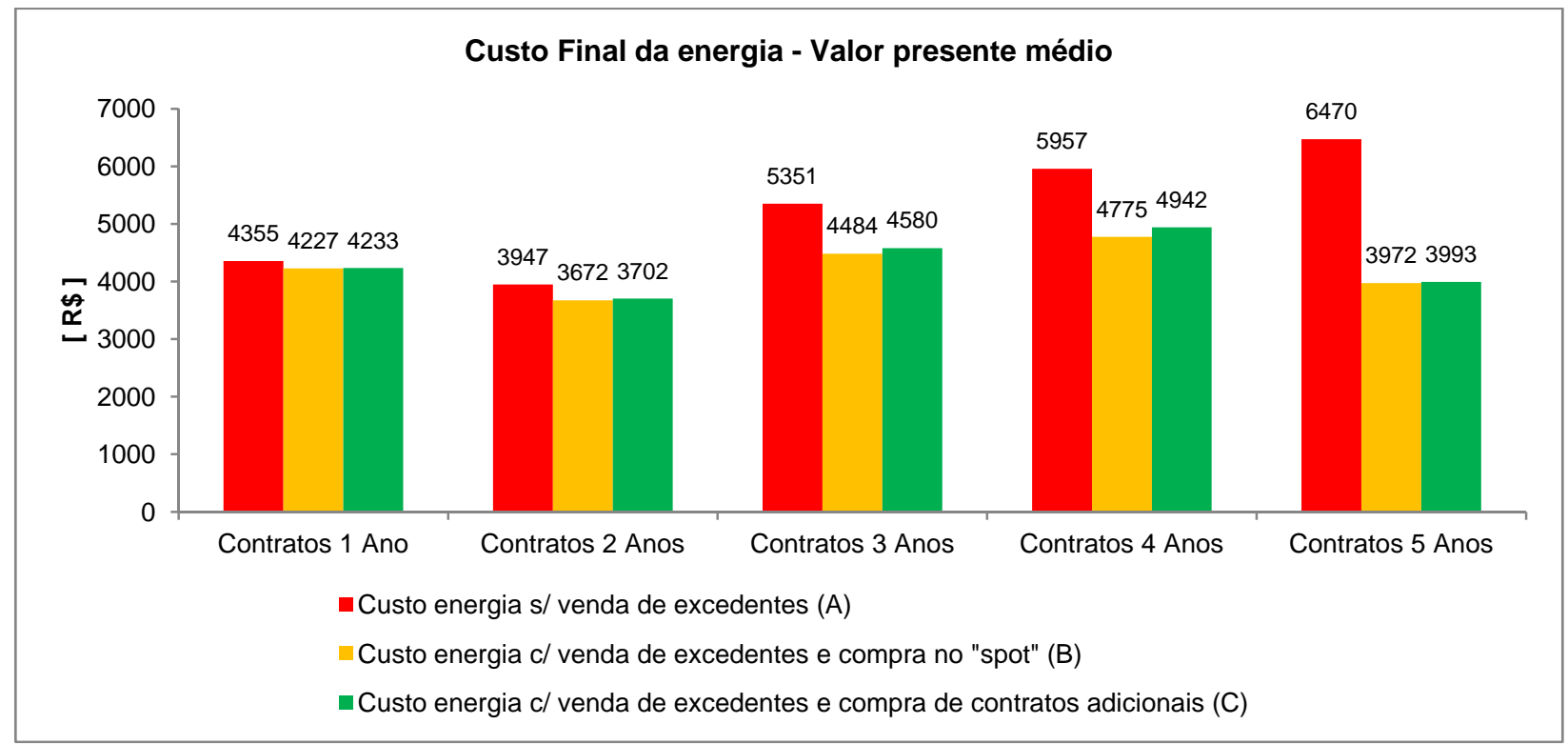

Gráfico 6.21 - Custo da energia nas distintas modalidades contratuais - cessão até o limite - Cenário Favorável

Ao comparar o custo final incorrido nesta condição na qual o Consumidor Livre tem a possibilidade da venda do excedente contratual até o limite permitido no contrato, notase que a modalidade contratual mais vantajosa para minimizar o custo com a compra 
de energia é a de 2 anos. Esta conclusão é diferente daquela quando simulada a venda do excedente contratual pelo limite admitido no contrato, posto que os contratos longos com 5 anos de duração eram os mais adequados, conforme o Gráfico 6.17. Essa alteração na modalidade contratual que otimiza a compra da energia é fundamentada em dois parâmetros de entrada que influenciam a simulação, são eles:

- A matriz de preços de custos marginais de operação (CMO) utilizada, projeta uma condição favorável de oferta de energia, ou seja, os preços spot são baixos na maior parte do tempo. Por isso o contrato de duração reduzida é favorecido, uma vez que leva em conta na sua formação os preços de curto prazo;

- A média para a redução de consumo adotada é de $10 \%$. Dessa maneira, mesmo os contratos mais curtos, até dois anos de duração, conseguem vender seus excedentes contratuais sem esbarrar no seu limite máximo, que é de $10 \%$. Aliás, os contratos mais longos, por exemplo, com cinco anos de vigência, também vendem seus excedentes contratuais, mas muitas das vezes distantes de poderem se desfazer do limite permitido, que é de $50 \%$ dos contratos firmados originalmente.

Portanto, como os preços no mercado de curto prazo são em média baixos e as reduções de demanda do Consumidor Livre são em média menores que $10 \%$, os contratos de 5 anos não chegam a vender, com frequência, seus limites máximos de excedentes, uma vez que estes admitem até $50 \%$ de cessão. Fato este, que ocorria quando adotado a cessão pelo limite máximo permitido em contrato, abordado na seção anterior. 
No Gráfico 6.22, novamente, os contratos de menor vigência alcançam os maiores preços contratuais quando analisada a Situação (A), ou seja, sem a possibilidade da venda de excedentes contratuais. Verifica-se, também, que com o aumento no tempo de duração dos contratos, menor é o valor de Preço Médio Máximo que o Consumidor Livre estará exposto nas três situações de contratação (A), (B) e (C), com durações contratuais variando de 1 a 4 anos.

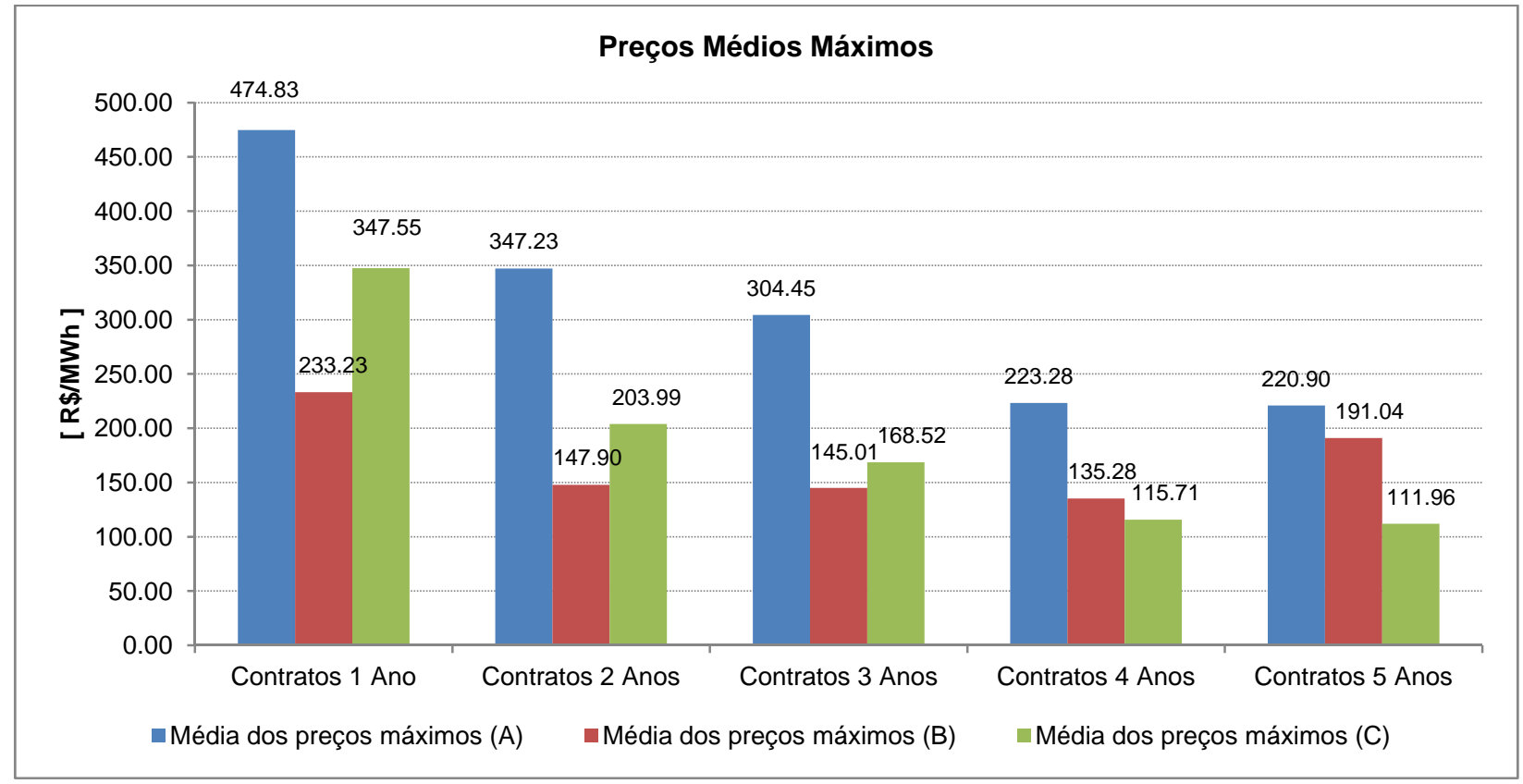

Gráfico 6.22 - Preços Médios Máximos nas distintas modalidades contratuais e para um Preço Máximo Admissível (PMA) de 168 R \$/MWh - cessão até o limite - Cenário Favorável

Além disso, quando adotado a cessão do excedente contratual até o limite permitido no contrato, nota-se uma sutil redução no Preço Médio Máximo enfrentado pelo Consumidor Livre quando este opta pela contratação de longo prazo com 5 anos de duração. A justificativa para esta diminuição está embasada naqueles dois parâmetros de entrada adotados: matriz de preços dos CMO's e redução média de consumo. 
Estes dois argumentos de entrada são importantes condicionantes da simulação, uma vez que projetam a expectativa de preços futuros no mercado de energia como, também, incorporam o perfil de carga do Consumidor Livre para o horizonte de 10 anos de análise.

O Gráfico 6.23 demonstra os valores de riscos médios nas distintas modalidades contratuais para um Preço Máximo Admissível de 168 R \$MWh.

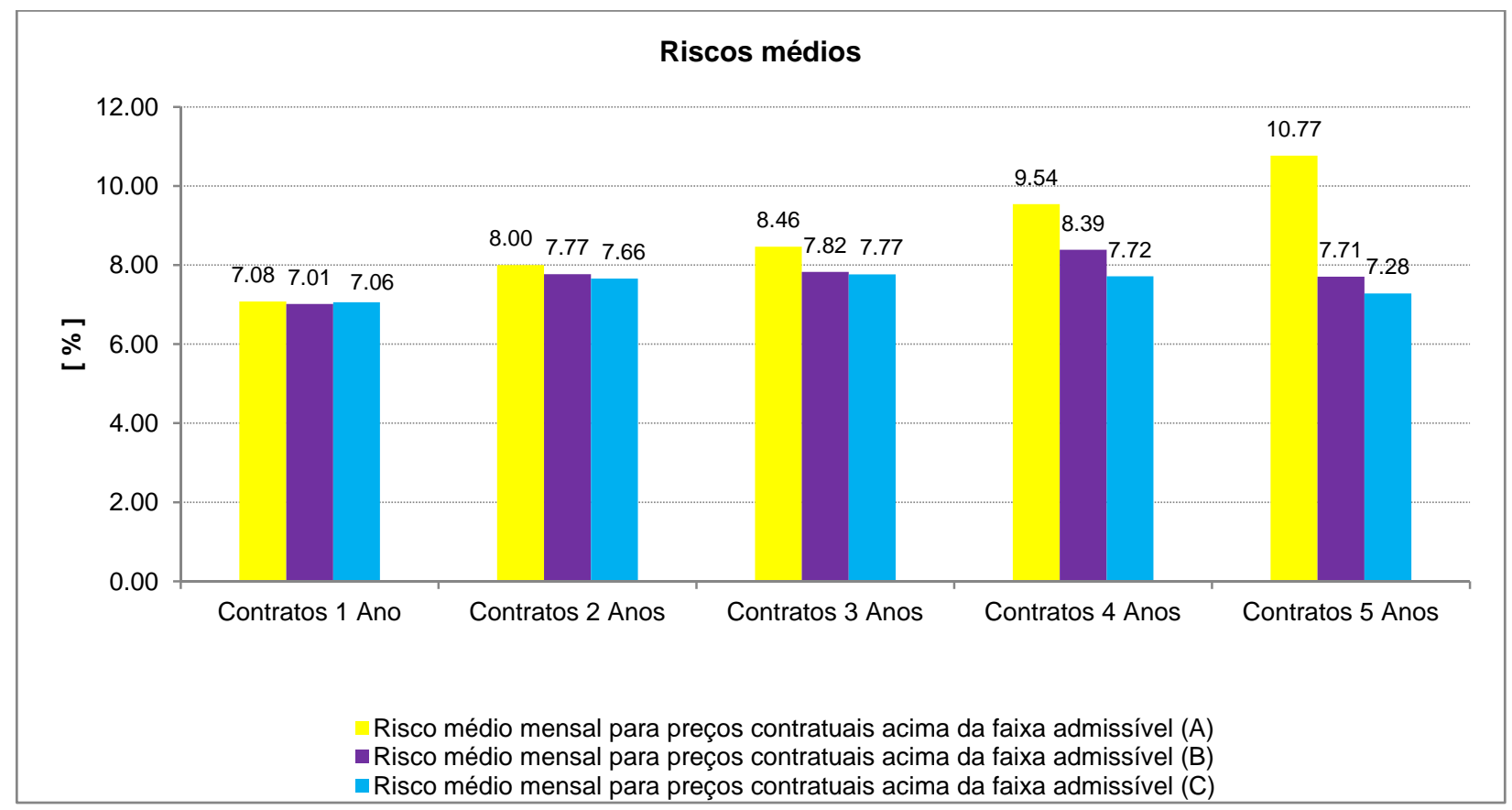

Gráfico 6.23 - Riscos médios de preços acima do PMA de 168 R \$/MWh - cessão até o limite Cenário Favorável

A impossibilidade da venda de excedentes é representada na Situação (A) e nesta condição quanto maior a duração contratual, maior é o risco médio dos preços figurarem acima do valor de PMA definido na simulação. Independentemente, da estratégia de contratação escolhida, nas Situações (B) e (C), a possibilidade da comercialização dos excedentes contratuais, até o limite admitido pela vigência dos 
acordos, reduziu o nível de exposição a riscos de preços quando comparada com a Situação $(A)$ que não contempla a flexibilização contratual.

Já para um valor de PMA de $240 \mathrm{R} \$ / \mathrm{MWh}$, valor $71 \%$ superior ao Preço da Energia Nova de 140 R\$/MWh estipulado na simulação, o risco médio de preços acima de PMA, Gráfico 6.24, tem seu comportamento inverso àquele verificado para PMA de 168 $\mathrm{R} \$ / M W h$. Ou seja, para as três situações de contratação (A), (B) e (C), quando variamos as durações contratuais de 1 até 4 anos, menor é o risco de exposição à preços superiores a PMA.

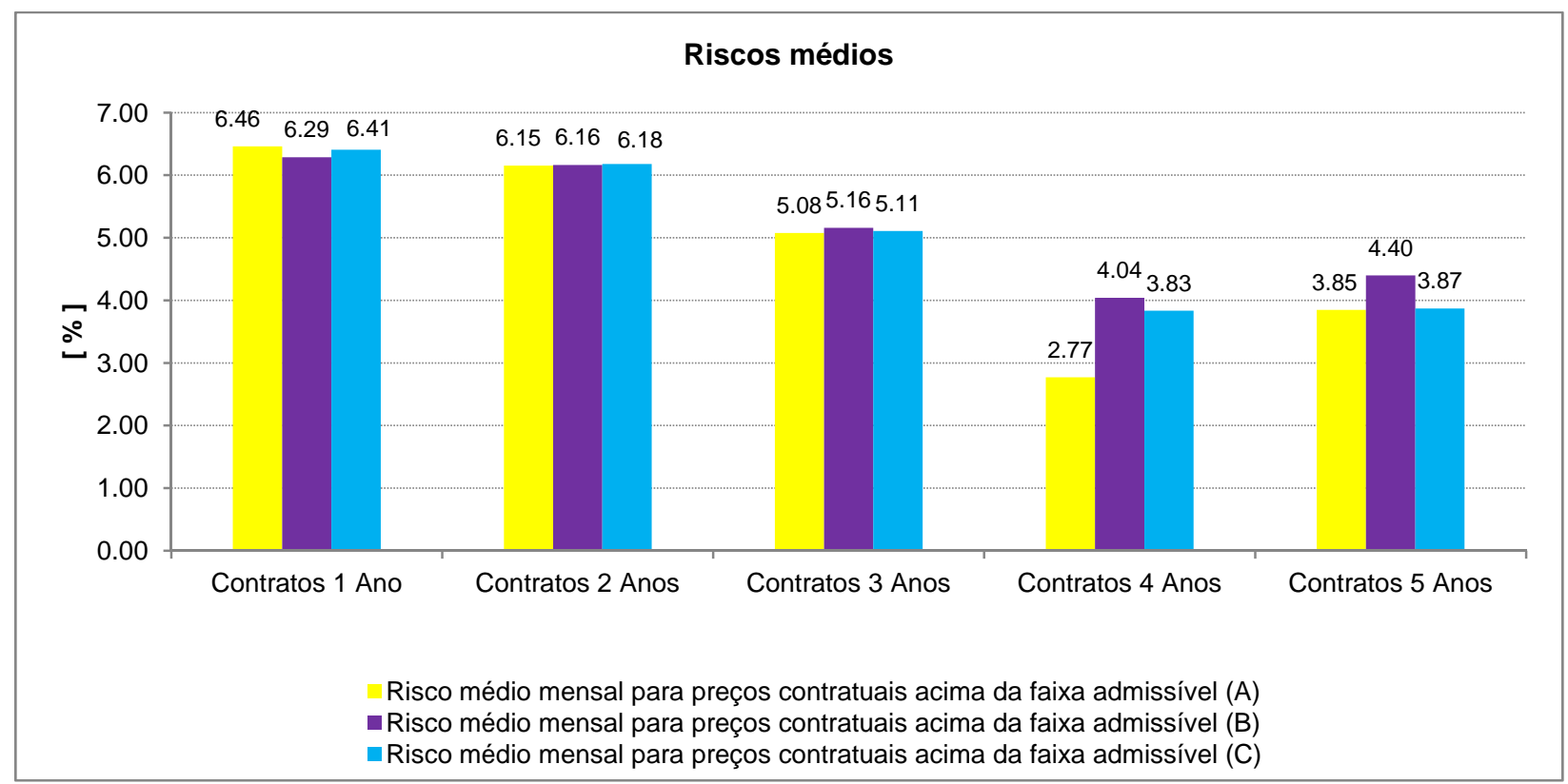

Gráfico 6.24 - Riscos médios de preços acima do PMA de 240 R $\$ / M W h$ - cessão até o limite Cenário Favorável

Os resultados obtidos no Gráfico 6.23 e no Gráfico 6.24 são semelhantes àqueles apresentados no Grafico 6.19 e no Gráfico 6.20 da seção anterior, onde os valores de riscos estão dentro das mesmas faixas percentuais, independente da simulação de 
cessão de excedentes "pelo limite" ou "até o limite" estabelecido pelas durações contratuais. Estes resultados explicitam que, para medir os valores de risco médio (RM), o critério não considera na metodologia de compilação dos resultados de simulação adotada, a ponderação do preço do contrato pelo montante de energia, MWmed, a ser comprado e incorporado à carteira de contratos do Consumidor Livre. Assim, um refinamento na análise do comportamento do risco de preços será feita na seção 6.2.1.3 - A aplicação do conceito de VARmod e, abordará uma outra métrica de risco para os preços dos contratos.

O custo de aquisição de energia incorrido pelo agente nas modalides contratuais foi exposto, até o momento, como um valor totalizado do gasto durante o período de estudo de 10 anos. Para ilustrar o comportamento do custo mensal nas modalidades contratuais de curto e longo prazos associado a um perfil de consumo do agente, são disponibilizados os Gráficos 6.25 e 6.26, respectivamente.

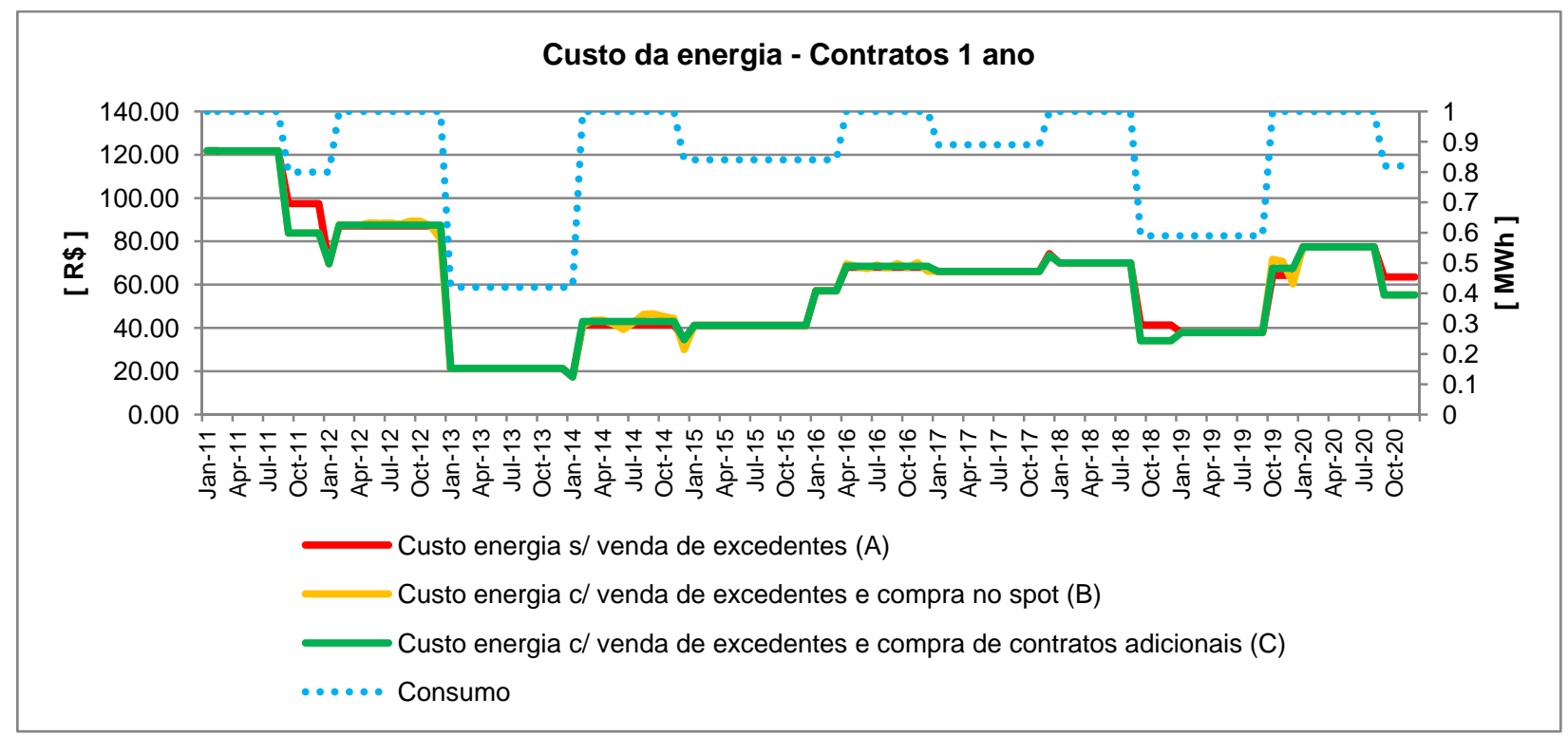

Gráfico 6.25 - Custo da energia mensal em uma modalidade contratual de curto prazo - cessão até o limite - Cenário Favorável 


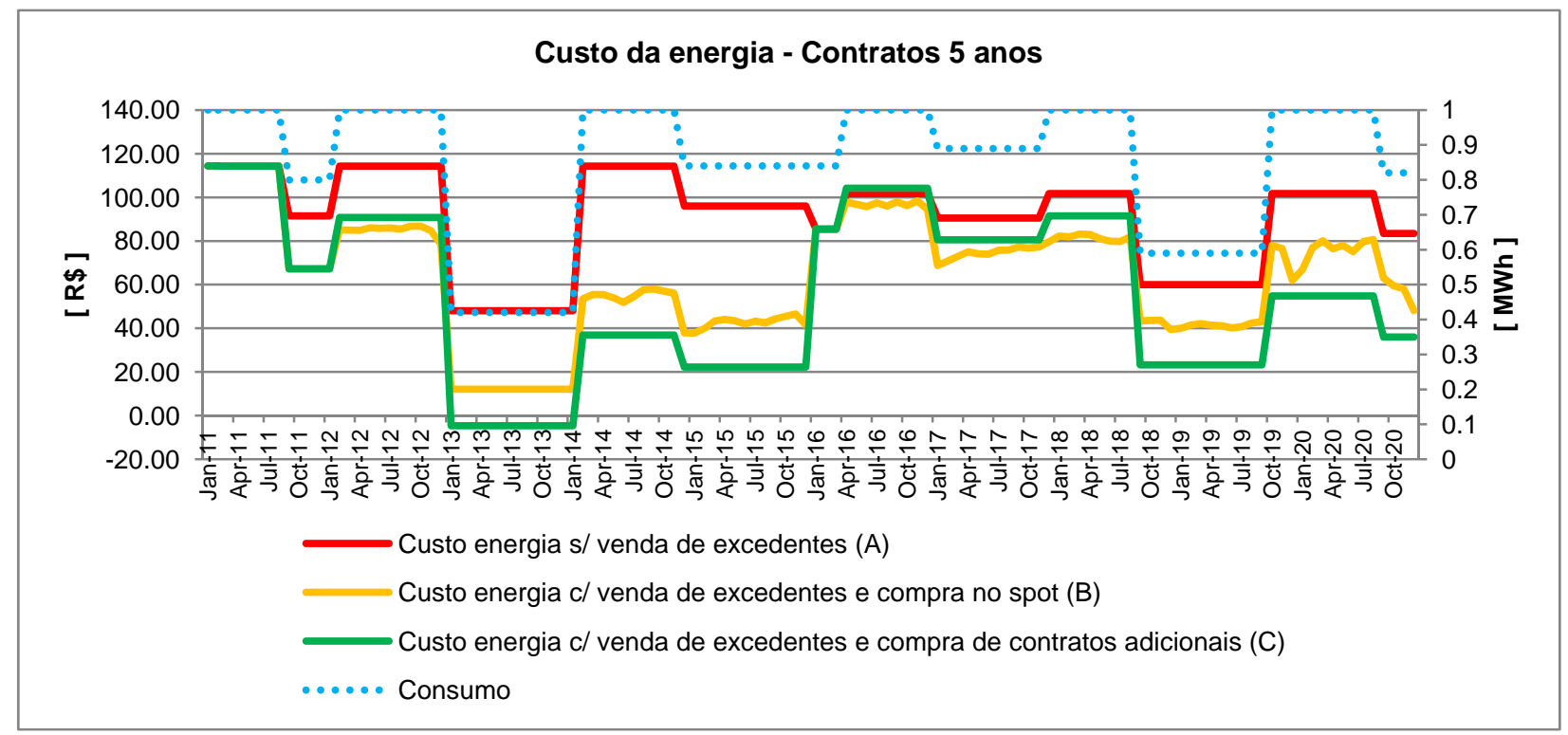

Gráfico 6.26 - Custo da energia mensal em uma modalidade contratual de longo prazo - cessão até o limite - Cenário Favorável

Observa-se que nos contratos curtos, o custo mensal é muito semelhante independente da situação de contratação escolhida: (A), (B) ou (C). Isto ocorre, pois os contratos de menor duração sofrem forte influência dos preços de curto prazo nestas três situações de contratação. Nota-se ainda que existem momentos nos quais ocorrem reduções de consumo e, por conseguinte, a impossibilidade da cessão dos excedentes contratuais, na Situação (A), submete o Consumidor Livre a custos mais elevados, o que pode ser comprovado pela curva representada em vermelho posicionada acima das demais curvas nestes instantes específicos.

Em contraposição, pode-se observar no Gráfico 6.26 que, nos contratos longos, o custo mensal pode sofrer sensíveis variações dependendo da situação de contratação $(A)$, (B) ou (C). 
Primeiramente, verifica-se que a impossibilidade da venda de excedentes nesta modalidade contratual de longo prazo, deixa o custo mensal mais elevado ao longo do horizonte de simulação, como mostrado pela permanência da curva em vermelho acima das demais curvas por quase a totalidade do período. A condição imposta pela contratação na Situação (B) tem um custo mensal intermediário, referenciado entre os custos incorridos nas situações (A) e (C). Neste tipo de contratação, por hipótese, na ocorrência de retomadas de consumo pelo Consumidor Livre, este recorre a contratos de duração reduzida no mercado de curto prazo, por isso a confirmação da elevada volatilidade dos valores de custos mensais e maior exposição aos preços de curto prazo do que àquelas deparadas na Situação (C).

Finalmente, a Situação $(C)$ configura-se como aquela que apresenta o menor custo mensal dentre as alternativas de contratação. Do Gráfico 6.26, identifica-se que existem instantes em que o custo mensal pode assumir valores negativos durante 0 período de análise. Este acontecimento é possível, uma vez que nos contratos longos há a flexibilidade de cessão contratual até o limite de $50 \%$ da energia contratada originalmente. Além disso, o preço de venda do contrato excedente, dependendo do momento de sua realização, pode ser superior ao preço de compra do contrato que originou o próprio excedente. A volatilidade dos valores de custos mensais nesta situação não é elevado. De fato, pois, por construção, a compra da energia nas retomadas de consumo do agente é feita através de contratos com duração definida entre o início da retomada de demanda e o vencimento do contrato da modalidade escolhida, reduzindo a susceptibilidade do Consumidor Livre aos preços praticados no mercado de curto prazo. 


\subsubsection{A aplicação do conceito de $\mathrm{VaR}_{\bmod }$}

As análises feitas até então, para os cálculos do risco, basearam-se na contabilização dos Preços Médios Máximos (PMM) contratuais que fossem classificados como superiores ao Preço Máximo Admissível (PMA). Ou seja, a partir do dado de entrada de PMA, enumeram-se todos os preços contratuais encontrados acima deste valor, de modo a se obter o Preço Médio Máximo (PMM) e o risco médio (RM).

A utilização do conceito de $V_{a} R_{\text {mod }}$ muda o enfoque para o cálculo do risco de preços, já que parte-se de um intervalo de confiança de $10 \%$, adotado nesta simulação e, elaborando sobre o conceito clássico de $\mathrm{VaR}$, chega-se no conceito de $\mathrm{VaR}_{\text {mod, }}$ que representa uma valorização ou desvalorização do preço contratual em relação ao preço de referência, que é o Preço da Energia Nova (PEN). Além do mais, a mensuração do risco, adotando o critério de $\mathrm{VaR}_{\bmod }$, visa capturar o comportamento do preço do contrato com sua ponderação pelo volume de energia a ser contratado pelo Consumidor Livre. Desse modo, o modelo possibilita a comparação de estratégias de contratação em base unificada, onde o valor do contrato de compra de energia é representado pelo preço do MWmed do portfólio de contratos do agente.

O Gráfico 6.27 indica os preços contratuais apresentados pelo conceito de $\mathrm{VaR}_{\text {mod }}$ nas situações (A), (B) e (C). 


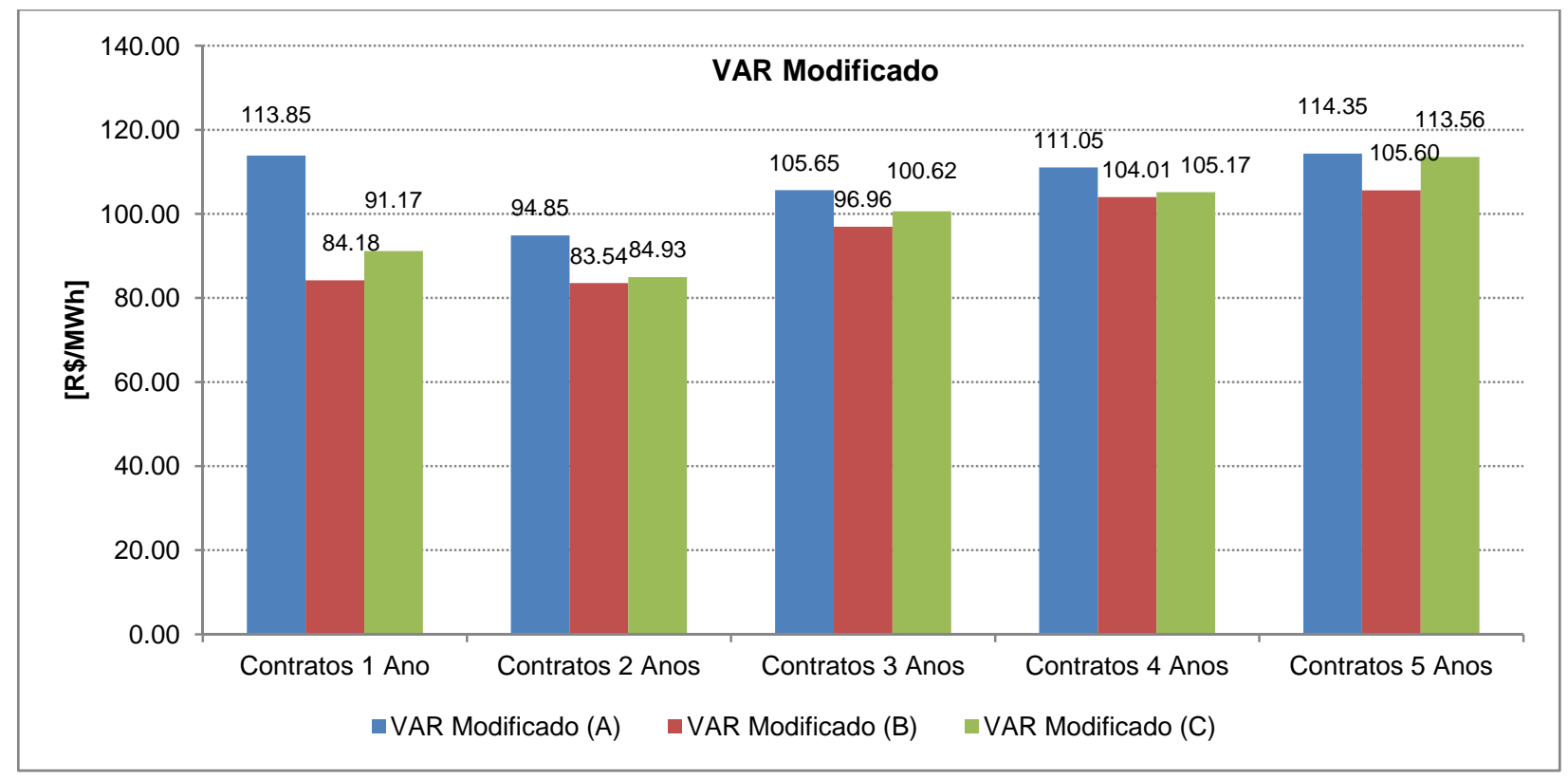

Gráfico 6.27 - Os preços contratuais através do conceito de $V_{a R_{m o d}}$ cessão até o limite - Cenário Favorável

O menor preço contratual pelo conceito de $\mathrm{VaR}_{\text {mod }}$ é encontrado nos contratos de 2 anos de duração. Na Situação (B), este valor é de 83,54 R\$/MWh. Este valor nos informa que este preço está 40,33\% inferior ao Preço da Energia Nova que é de 140 $\mathrm{R} \$ / \mathrm{MWh}$. E, existe ainda, $10 \%$ de probabilidade de que os preços contratuais figurem acima do valor de $83,54 \mathrm{R} \$ / \mathrm{MWh}$.

À exceção dos contratos de 2 anos de duração, nota-se que o aumento no tempo de vigência contratual desloca o valor do $\mathrm{VaR}_{\bmod }$ para valores mais elevados, isto para todas as três situações de contratação (A), (B) e (C). Na Situação (C), o preço do contrato de 5 anos é de $113,56 \mathrm{R} \$ / \mathrm{MWh}$, o que indica um $\mathrm{VaR}_{\text {mod }}$ de $18,89 \%$ para um intervalo de confiança de $10 \%$. Ou seja, o preço na modalidade de longo prazo de 5 anos está 18,89\% inferior ao Preço da Energia Nova (PEN), mas existe 10\% de probabilidade de que este valor esteja acima de 113,56 R $\$ / \mathrm{MWh}$. 
Portanto, com a aplicação do conceito de $V R_{\text {mod }}$ lançou-se mão de mais um artifício que, juntamente com a informação do custo total de aquisição da energia, pode auxiliar a tomada de decisão do Consumidor Livre. A assertiva se justifica, posto que $\circ \mathrm{VaR}_{\text {mod }}$ é uma medida da valorização ou da desvalorização do preço do MWmed em relação ao preço de expansão da oferta de geração (PEN), sempre conjugado com o intervalo de confiança e com o período de análise.

\subsubsection{Cenário Escassez}

O intuito desta seção é mostrar o potencial de análise levando-se em consideração uma matriz de preços contrastante àquela adotada na seção 6.2.1, que aponta para um cenário favorável no tocante aos preços de liquidação de diferenças - PLD ao longo do horizonte de simulação. Aqui, o enfoque é retratar um ambiente pessimista, no qual os preços no mercado de curto prazo estão bastante elevados, podendo refletir um crescimento acelerado do mercado frente à oferta ou, também, atrasos nos cronogramas de incorporação de obras ao parque de geração do sistema elétrico.

\subsubsection{1. $\quad$ Cessão de excedentes até o limite previsto na modalidade contratual}

Em primeiro lugar, disponibiliza-se o custo final, $C_{\text {final, }}$ incorrido na contratação da energia nas distintas modalidades contratuais e, na seqüência, se compara também as condições definidas neste estudo:

- Situação $(A)$ : sem a possibilidade da venda de excedentes contratuais;

- Situação (B): com a possibilidade da venda de excedentes e compra de retomada de consumo através de contratos curtos no mercado spot. Os detalhes 
desta condição estão discriminados no tópico - 5.6 A cessão dos excedentes contratuais e sua precificação;

- Situação (C): com a possibilidade da venda de excedentes e compra de retomada de consumo através de contratos coincidentes com o vencimento do contrato que originou o excedente contratual. Novamente, os detalhes desta condição estão expostos no tópico - 5.6 A cessão dos excedentes contratuais e sua precificação.

O gráfico 6.28 aponta os contratos de longo prazo, com cinco anos de duração, como os mais promissores para minimizar os gastos com a aquisição de energia, na ocasião em que é sinalizado um cenário de PLD’s elevados. Este resultado é confirmado analisando as três hipóteses de contratação, quais sejam: Situação (A) - sem a possibilidade da venda de excedentes contratuais, Situação (B) - com a possibilidade da venda de excedentes e compra de retomada de consumo no mercado de curto prazo e na Situação (C) - com possibilidade da venda de excedentes e aquisição de lastro de consumo através de contratos com duração coincidente com o vencimento do contrato que originou a cessão contratual. O menor custo é encontrado no acordo firmado com cinco anos de vigência e, na Situação (C) de contratação, este valor é igual a $\mathrm{R} \$ 6316$. 


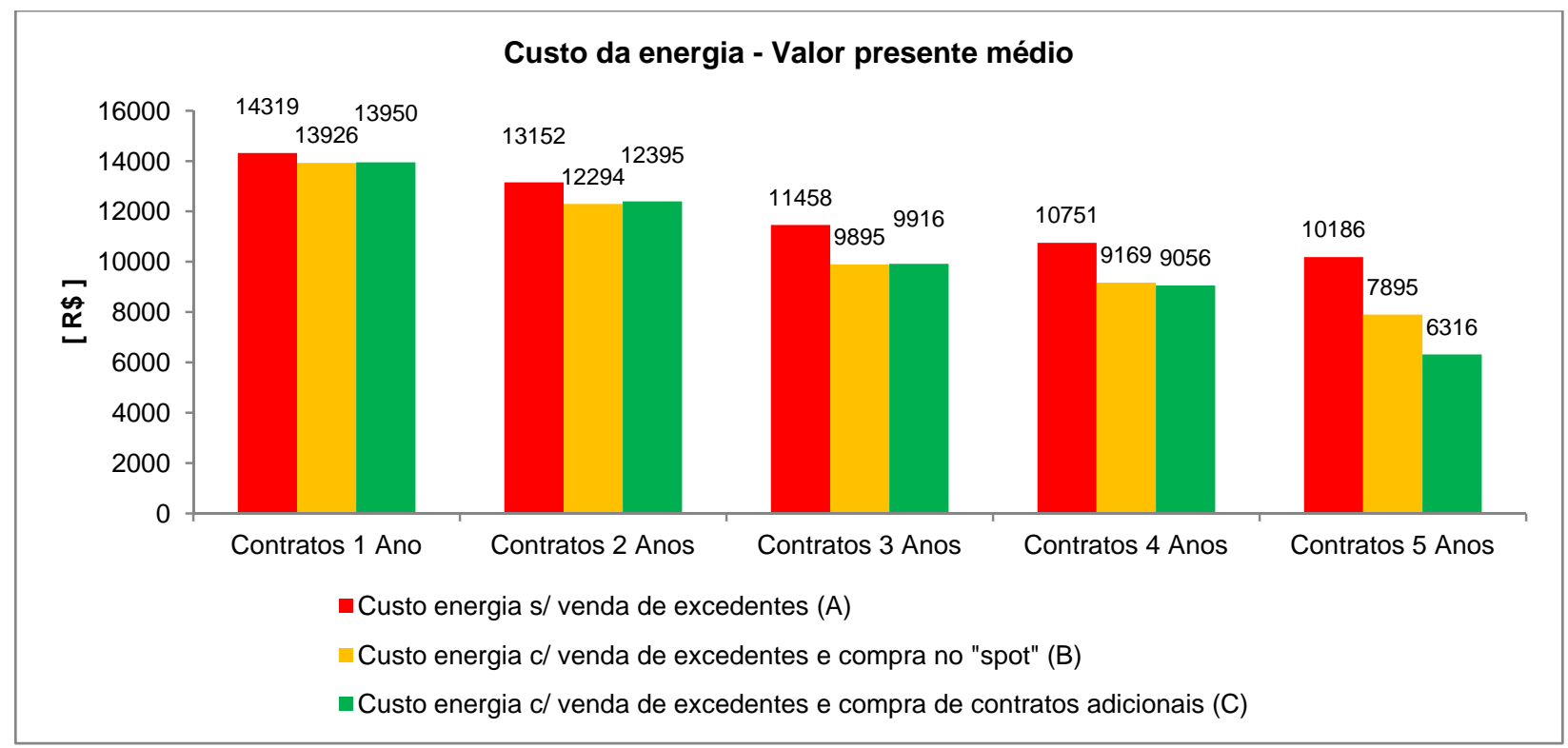

Gráfico 6.28 - Custo da energia nas distintas modalidades contratuais - cessão até o limite - Cenário Escassez

Depreende-se, também, do mesmo gráfico 6.28 , que a possibilidade existente de comercialização de sobras contratuais, retratadas nas Situações $(B)$ e $(C)$, reduz o custo final de compra da energia em todas as modalidades de contratação consideradas, quando se compara com o gasto incorrido na ausência do mecanismo de flexibilização contratual representado aqui através da Situação (A). Fica evidente que uma vez feita a opção pela comercialização de excedentes contratuais, seja na condição (B) ou mesmo na estratégia (C), os custos nestas situações são bastantes semelhantes quando avaliados os tipos de contratos com vigência variando entre um e quatro anos. No entanto, ao aferir estas mesmas condições de contratação, nos contratos longos, com cinco anos de duração, nota-se sensível redução de custo, vinte por cento (20\%), ao decidir pela Situação $(C)$ - $R \$$ 6316, em contraposição à Situação (B) - $\mathrm{R} \$ 7895$. 
Isto porque, como temos por hipótese que os preços no mercado spot são elevados e, na Situação (B), o Consumidor Livre recorre, frequentemente, ao mercado de curto prazo para lastrear seu requisito energético, este acaba expondo-se aos preços praticados no mercado, que são mais elevados em conjunturas desfavoráveis. Fato este que é minimizado na Situação $(C)$ de contratação, pois o Cliente Livre firma contratos com prazos mais extensos, com duração compreendida entre o momento do reestabelecimento de seu consumo e o vencimento do contrato que originou 0 excedente contratual, dessa maneira eximindo o consumidor de ter que contratar no mercado spot recorrentemente e a preços indesejáveis.

Neste cenário de preços elevados no mercado de curto prazo, outro aspecto a ser considerado é o nível de preços a que o Consumidor Livre está exposto quando opta por determinada estratégia de contratação, de acordo com o Gráfico 6.29.

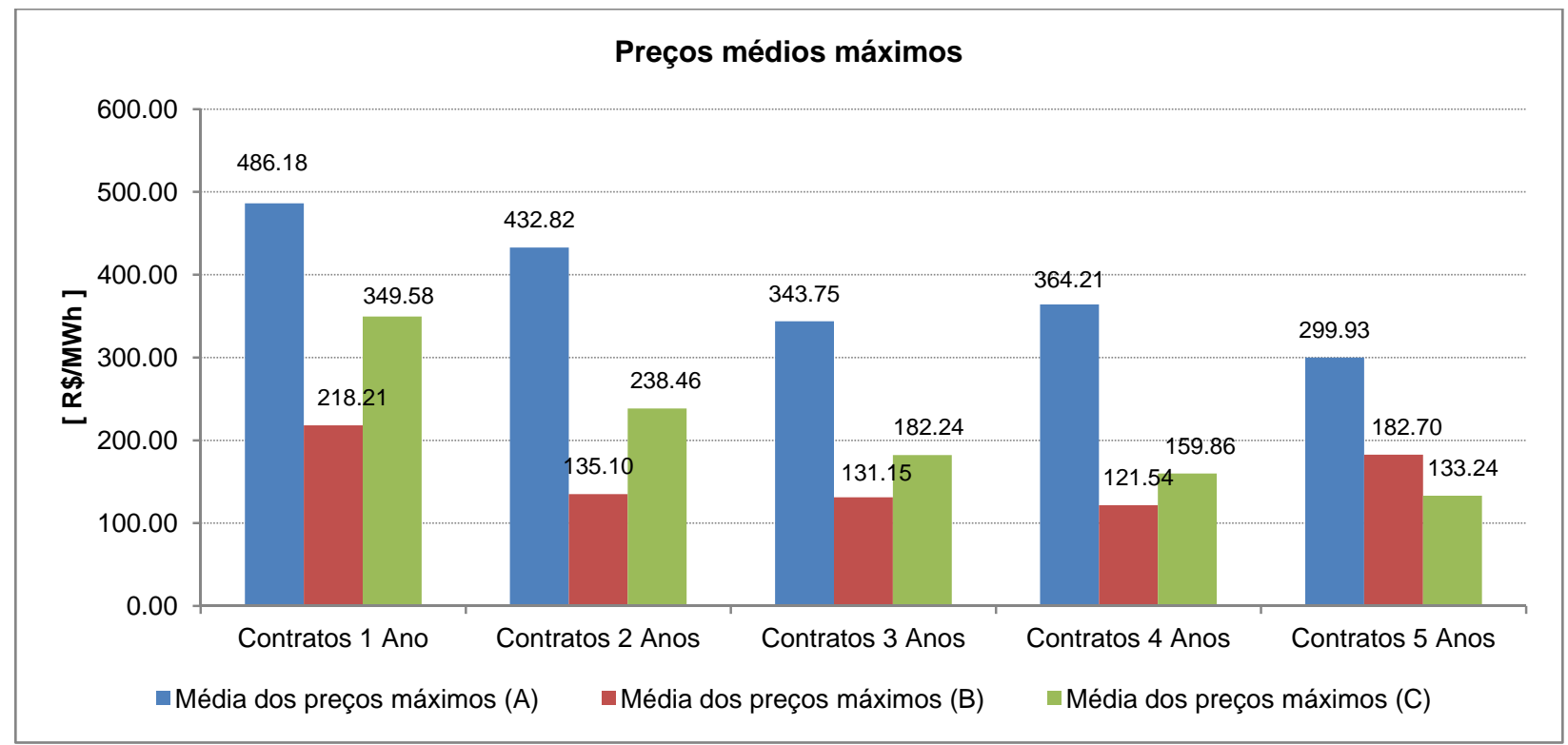

Gráfico 6.29 - Preços Médios Máximos nas distintas modalidades contratuais e para um Preço Máximo Admissível (PMA) de 168 R\$/MWh - Cessão até o limite - Cenário Escassez 
Uma primeira análise do gráfico anterior, deixa claro que, quando é dada ao Consumidor Livre a possibilidade da comercialização de excedentes contratuais, menor é sua exposição a Preços Médios Máximos - PMM, independente da modalidade contratual adotada, seja esta de curto ou de longo prazo.

Constata-se também que, quanto maior é o tempo de vigência contratual, menor é o preço médio máximo do MWmed a que o Cliente Livre está submetido. Este comportamento pode ser claramente notado na Situação (A) de contratação - sem a possibilidade da venda de excedentes e, também, na Situação (C) - com a possibilidade da venda de excedentes e recompra através de contratos com duração coincidente com o vencimento do contrato que originou a cessão contratual, conforme o Grafico 6.29.

O aumento no prazo contratual, novamente, diminui a exposição do Consumidor Livre a preços elevados quando sujeito à Situação $(B)$ de contratação - com a possibilidade da venda de excedentes e recompra de retomada de consumo através de contratos curtos no mercado spot. Uma ressalva é feita quando se toma como ponto de partida os contratos com quatro anos de duração e, em seguida, se analisa o nível de preços médios máximos do MWmed nos contratos com cinco anos de vigência nesta mesma situação. De fato, pois nesse caso há um aumento no preço máximo do MWmed encontrado. Isto porque, função do cenário adotado, os preços no mercado de curto prazo estão elevados e, nos contratos com cinco anos de duração, quando ocorre venda de excedentes com retomadas de consumo futuras, o Cliente Livre permanece comprando o lastro contratual para seu novo requisito energético no mercado spot e, repete essa ação até a renovação do contrato majoritário com duração de cinco anos, 
consequentemente ficando muito mais tempo exposto aos preços de curto prazo do que nos contratos com duração de quatro anos.

Cabe, agora, aferir sobre os critérios de risco propostos nesta simulação. O primeiro deles é o Risco Médio de preços (RM) que enumera a probabilidade de ocorrência de preços, não ponderados pelo MWmed, acima de um valor de referência estipulado pelo Consumidor Livre. Este valor de referência no presente trabalho é denominado Preço Máximo Admissível (PMA) e, assume dois valores $168 \mathrm{R} \$ / \mathrm{MWh}$ e $240 \mathrm{R} \$ / \mathrm{MWh}$, de acordo com o Gráfico 6.30 e com o Gráfico 6.31, respectivamente.

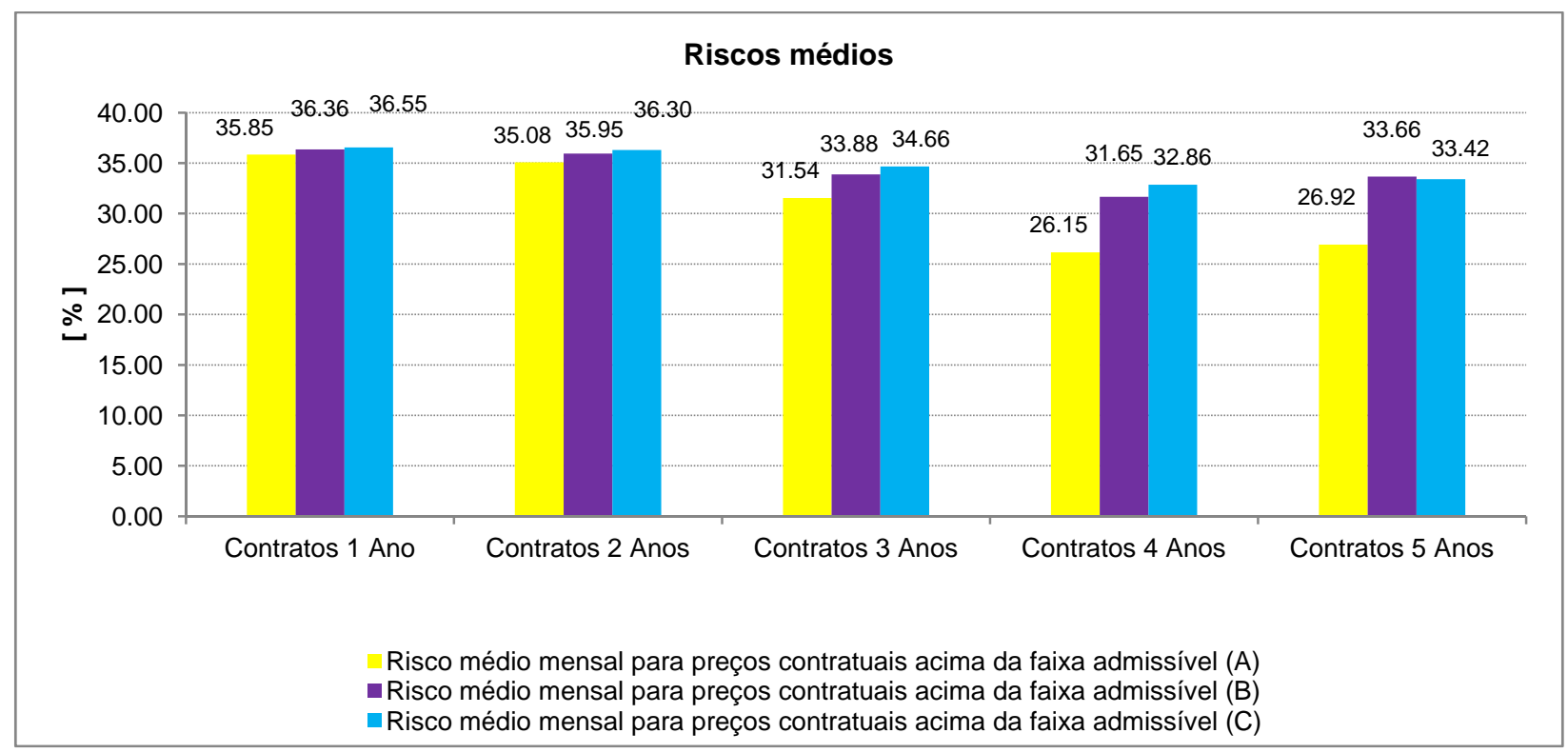

Gráfico 6.30 - Riscos médios de preços acima do PMA de 168 R \$/MWh - cessão até o limite Cenário Escassez

Do Gráfico 6.30, o Risco Médio calculado apresenta-se na faixa entre 26,15\% e $36,36 \%$ de probabilidade de ocorrência de preços acima de $168 \mathrm{R} \$ / \mathrm{MWh}$ para as diversas modalidades contratuais ao longo do horizonte de simulação. 


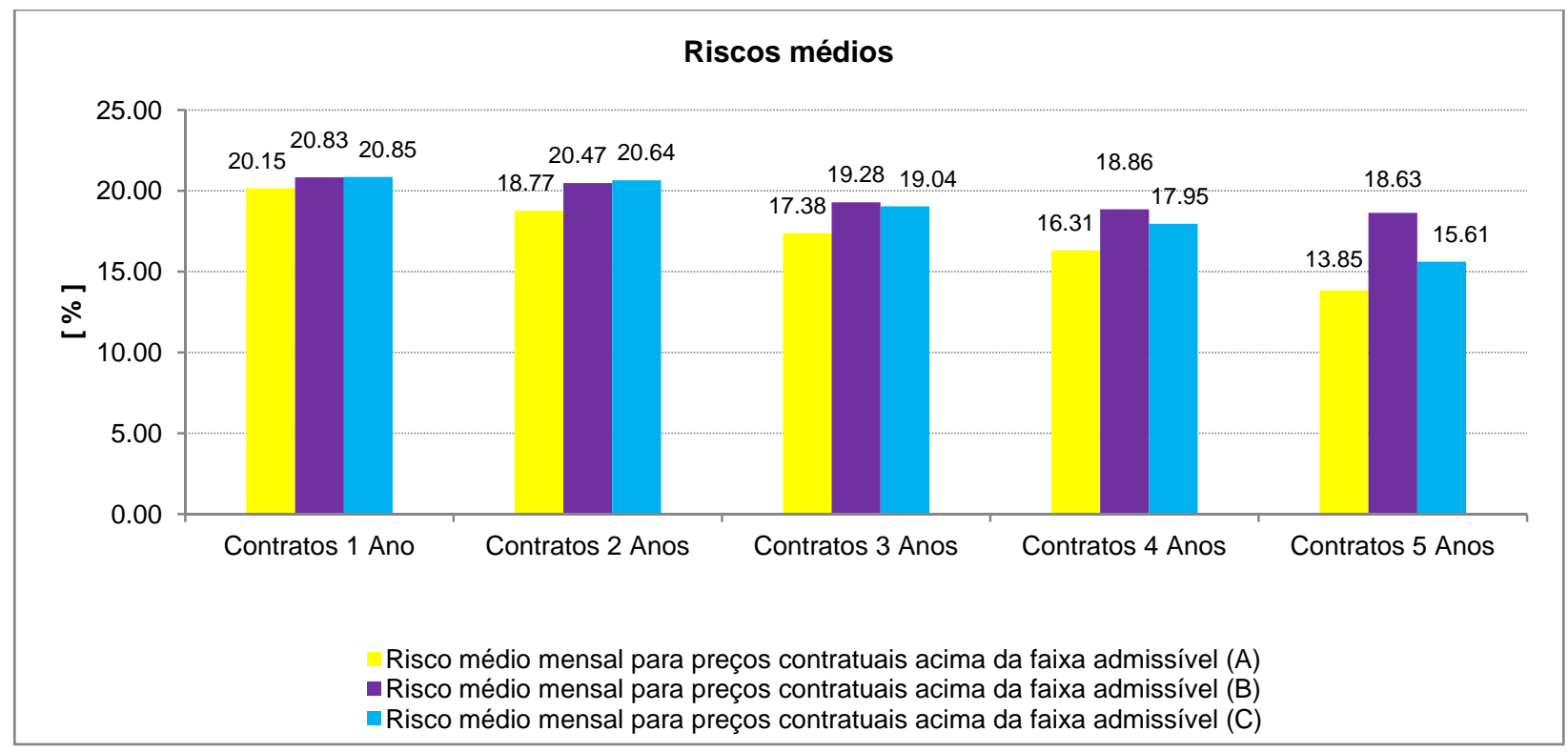

Gráfico 6.31 - Riscos médios de preços acima do PMA de 240 R \$/MWh - cessão até o limite -

Cenário Escassez

Já o Gráfico 6.31, que mede a probabilidade de ocorrência de preços acima de 240 $\mathrm{R} \$ \mathrm{MWh}$, indica a faixa entre $13,85 \%$ e $20,85 \%$ para as modalidades contratuais disponíveis dentro do mesmo intervalo de tempo utilizado na simulação.

Estes valores de riscos médios apresentados são maiores do que aqueles indicados na seção 6.2.1, uma vez que a precificação dos contratos está embasada em uma matriz formada por preços de liquidação de diferenças bastante elevados, repercutindo em maiores riscos médios ao longo do horizonte de contratação.

Aliás, uma primeira abordagem dada aos gráficos parece relacionar que a possibilidade da venda de excedentes contratuais expõe o Consumidor Livre a riscos maiores de preços acima de PMA, quando rivalizamos estes resultados com a ausência da flexibilização contratual. Esta conclusão não é verdadeira quando elucidamos o critério de risco abordado, posto que o Risco Médio - RM, somente enumera a probabilidade 
de ocorrência de preços acima do Preço Máximo Admissível - PMA, enquanto desconsidera a ponderação do preço da energia ofertada no mercado na composição do preço do MWmed ao ser incorporado ao portfólio existente de contratos do Consumidor Livre. Por essa razão é disponibilizado na seção seguinte o conceito de Value at Risk Modificado $\left(\mathrm{VaR}_{\text {mod }}\right)$.

\subsubsection{A aplicação do conceito de $\mathrm{VaR}_{\bmod }$}

O objetivo deste tópico é complementar a análise de risco empreendida anteriomente.

O risco aqui é um dado especificado no início da simulação e, define o intervalo de confiança que compreenderá os preços, agora ponderados em relação ao preço do MWmed a ser incorporado a carteira de contratos do Consumidor Livre, possíveis de acontecer ao longo do horizonte de estudo. O Gráfico 6.32 indica esses preços possíveis para um intervalo de confiança estipulado em $10 \%$.

Reincidentemente, é notado que o aumento no tempo de duração dos contratos diminui a exposição à preços elevados, tanto na Situação $(A)$ - sem a possibilidade da venda de excedentes contratuais, como também na Situação $(C)$ - com a possibilidade da venda de excedentes e compra de retomada de consumo através de contratos coincidentes com o vencimento do contrato que originou o excedente contratual. Para a Situação (C), o menor valor de $204,20 \mathrm{R} \$ / \mathrm{MWh}$ é alcançado no contrato com cinco anos de duração. Este preço indica uma valorização de 45,85\% em relação ao Preço da Energia Nova de $140 \mathrm{R} \$ / \mathrm{MWh}$ e, portanto, existe ainda a chance de $10 \%$ dos preços encontrados ao longo do horizonte de análise figurarem acima do valor de $204,20 \mathrm{R} \$ / \mathrm{MWh}$. 


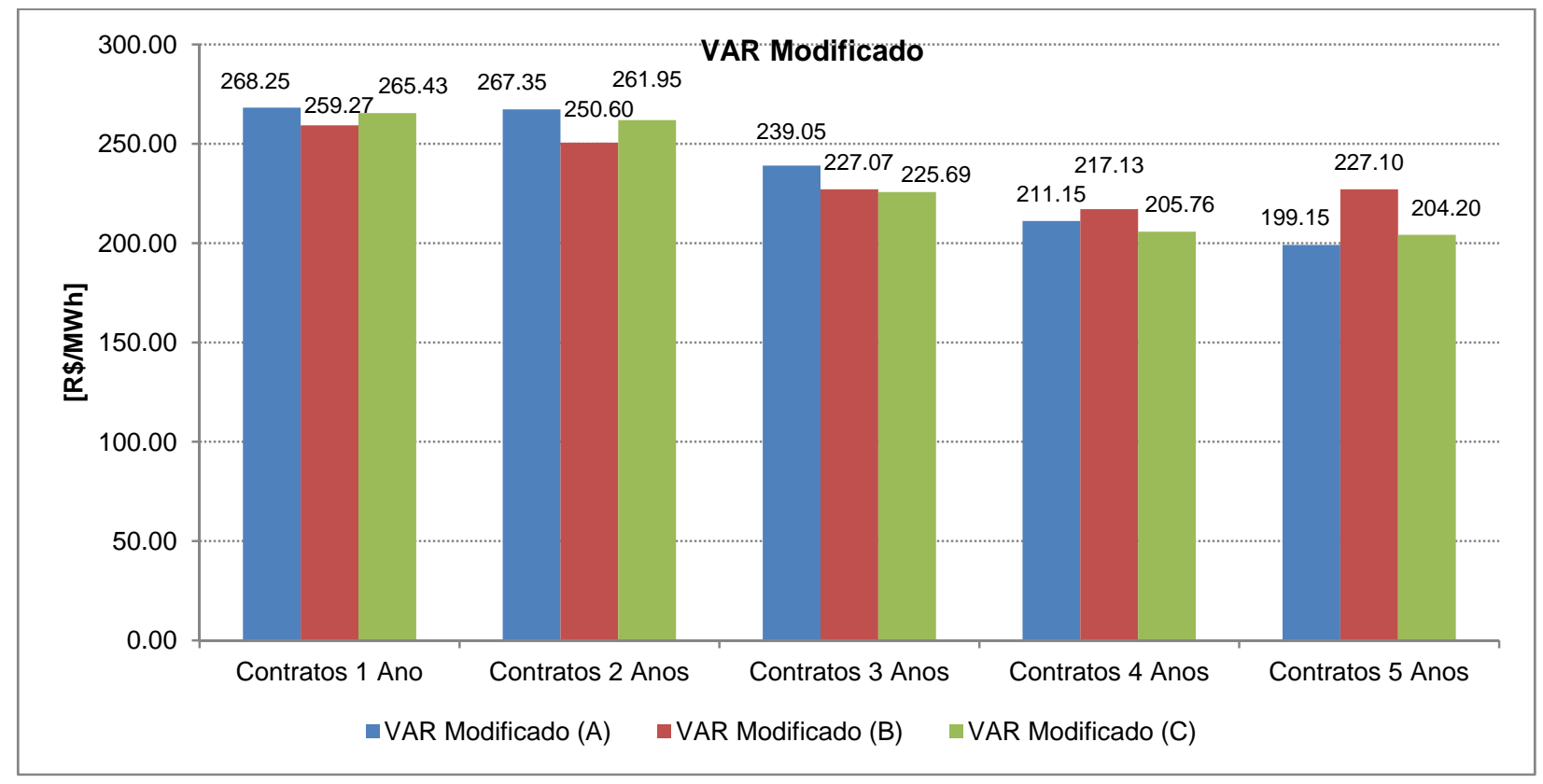

Gráfico 6.32 - Os preços contratuais através do conceito de $\mathrm{VaR}_{\bmod }$ - cessão até o limite - Cenário Escassez

$\mathrm{Na}$ Situação (B) de contratação, também se verifica que o aumento no tempo de vigência dos acordos, variando entre um e quatro anos, diminui o nível de preço a que o Consumidor Livre está submetido. Entretanto, notamos um aumento no preço do MWmed quando se toma como ponto de partida o contrato com quatro anos de duração, onde o preço do $M W m e d$ é de $217,13 \mathrm{R} \$ / \mathrm{MWh}$ e, em seguida, se alcança o contrato longo, com cinco anos de validade, no qual o preço do MWmed a ser contratado é de 227,10 R\$/MWh. Em primeiro lugar, este comportamento pode ser interpretado pela condição imposta à esta situação de contratação, em que o Consumidor Livre recorre ao mercado de curto prazo nos momentos em que há restabelecimento de seu requisito energético e, fica nestas ocasiões, exposto aos 
preços praticados neste mercado. Lembrando que por hipótese, os preços spot são bastante elevados, ou seja, a simulação projeta uma matriz de PLD's altos, os resultados se justificam. Por fim, os contratos com cinco anos de duração são aqueles que proporcionam o maior limite de cessão contratual dentre os contratos aqui simulados. Este percentual é de $50 \%$. Isto significa que na eventualidade de ocorrência de uma redução de consumo por parte do Consumidor Livre com igual ou superior profundidade e, consequente venda de excedentes, uma retomada de demanda por parte deste cliente no futuro, acarretará a contratação de energia a um montante equivalente à $50 \%$ do seu requisito energético e, portanto, o preço do MWmed encontrado no mercado de curto prazo ponderará o seu portfólio de contratos desfavoravelmente, uma vez que corresponderá a uma parcela substancial do seu consumo e a preços médios, em vigor no mercado, extremamente elevados. 


\section{CONCLUSÕES}

Para os dois cenários aqui apresentados verifica-se a eficiência da contratação de longo prazo na proteção do Consumidor Livre contra a volatilidade dos preços spot praticados no Mercado de Curto Prazo. É fundamental salientar a importância da definição do Preço Máximo Admissível (PMA) aderente ao agente, pois esse parâmetro reflete o perfil de aversão ao risco do Consumidor Livre e, além disso, recebe influência direta da conjuntura vivenciada no período da renovação contratual.

Paralelamente, ratificou-se nos contratos com curta duração, que é pequena a sensibilidade do risco à variação do Preço Máximo Admissível quando comparada aos contratos de longo prazo.

O intuito dos critérios de risco aqui propostos foi quantificar o número de transgressões dos preços dos contratos ao Preço Máximo Admissível e não à apreciação do grau de profundidade das infrações medidas.

As conclusões relativas à melhor estratégia de contratação de energia apontam os contratos de longo prazo como os mais promissores, na ótica do Consumidor Livre, visando uma otimização do seu balanço econômico-financeiro, ponderando valor esperado e risco financeiro. De fato, contratos de maior duração permitem limitar a variabilidade de preços contratuais enfrentados pelo consumidor, se recorresse com freqüência a negociações para renovações, de vez que contratos curtos sofrem muito maior influência da conjuntura, refletida nos preços de curto prazo, quando de sua precificação. 
Nessa perspectiva, o Consumidor Livre obtém uma diminuição do risco de exposição aos preços praticados no mercado de curto prazo, além de dispor de flexibilidade, nos momentos em que existir a necessidade de cessão dos excedentes contratuais em momentos ecônomicos desfavoráveis ao segmento no qual esteja inserido. Além disso, a possibilidade de cessão de contratos quando de uma redução de consumo do Cliente Livre, se afigura sempre em uma alternativa interessante, particularmente para permitir obter a expectativa de custos de aquisição mais reduzida.

Com relação à comercialização de sobras contratuais, este dispositivo regulatório em princípio não agrega riscos para o agente titular da energia que será repassada pelo Consumidor Livre, pelo fato de que o contrato permanece integralmente de responsabilidade do comprador original. Em outras palavras, a cessão de excedentes cria a possibilidade do Consumidor Livre atuar como um Comercializador, que tem contrato de compra para lastrear o montante cedido. As obrigações do contrato original, convém reafirmar, não são absolutamente alteradas com a implementação do mecanismo de venda de excedentes.

Claro está que o Consumidor Livre que adquiriu um contrato de energia de um agente gerador ou comercializador, somente cederá parte de seu contrato e ainda assim voluntariamente. Ou seja, pode condicionar a venda de seu excedente contratual ao atendimento de critérios de preço no momento em que os excedentes se apresentam e que ponderem sua carteira de contratos satisfatoriamente. Por conseguinte, 0 consumidor pode exercer a opção da venda de excedentes se os preços estiverem interessantes na conjuntura vigente. 
Do lado do Consumidor Livre, ao vender excedentes, estará assumindo o risco de crédito correspondente ao montante cedido. No contexto da regulamentação sinalizada pelo MME, o cedente (Consumidor Livre) passará a ter receita proveniente da venda de sua sobra contratual e, por sua vez estará sujeito ao recebimento ou não da parcela cedida do contrato existente.

Ainda do ponto de vista do Consumidor Livre que pratica a cessão de parte de um contrato, subsistirá o risco de preço na compra de energia, já que o cedente pode ter sua demanda energética reestabelecida/retomada eventualmente e, desse modo, irá se expor aos preços praticados no mercado no momento de lastrear seu novo requisito energético.

Cabe, também, salientar a existência do risco de volume, que com o risco de preço compõe o chamado risco de mercado, que sujeita o Consumidor Livre à impossibilidade da venda de seus excedentes contratuais mesmo quando da sua materialização, se o mercado não tiver condição de absorver. Nessa situação, o Consumidor Livre vai comercializar seus excedentes como se prevalecesse ainda a regra de hoje, ou seja, diretamente no mercado de curto prazo, ao valor do preço de liquidação de diferenças (PLD).

A flexibilização da venda de excedentes contratuais apenas atuaria para melhor alocar energia entre os agentes livres, uma vez que possibilitaria a transferência de montantes residuais de energia entre os consumidores presentes neste mercado, otimizando a composição de suas carteiras de contratos e evitando riscos de exposição a preços 
baixos no mercado de curto prazo, na hipótese de não ser possível praticar a cessão integral de excedentes quando estes se apresentam.

Ademais, não haveria uma injeção de energia "nova" no sistema elétrico, advinda da liberalização da comercialização de excedentes contratuais, fato que não exime a necessidade de expansão da oferta para o Mercado Livre de energia. O mecanismo sendo criado, na verdade, tem um papel importante na expansão do sistema, posto que mitiga o risco dos Consumidores Livres assumirem contratos de longo prazo, que são efetivamente o dispositivo que alavanca os investimentos em geração, visto que fornece a garantia necessária para a busca de financiamento para a construção de novas plantas geradoras. 


\section{REFERÊNCIAS BIBLIOGRÁFICAS}

AGÊNCIA NACIONAL DE ENERGIA ELÉTRICA (ANEEL). Nota Técnica № 118/2003. Regulamentação da curva do custo do déficit de energia elétrica e do limite máximo do preço de mercado de curto prazo. Brasília, nov. 2003. Disponível em: <http://www.aneel.gov.br/biblioteca/pesquisadigit.cfm>. Acesso em: mar. 2008.

Resolução Normativa №247/2006. Estabelece as condições para a comercialização de energia elétrica, oriunda de empreendimentos de geração que utilizem fontes primárias incentivadas, com unidade ou conjunto de unidades consumidoras cuja carga seja maior ou igual a 500 kW, no âmbito do Sistema Interligado Nacional - SIN. Brasília, dez. 2006. Disponível em: <http://www.aneel.gov.br/biblioteca/pesquisadigit.cfm>. Acesso em: mar. 2008.

BRASIL. Lei № 9074/1995. Estabelece normas para a outorga e prorrogações das concessões e permissões de serviços públicos e dá outras providências. Brasília, jul. 1995. Disponível em: <http://www.aneel.gov.br/biblioteca/pesquisadigit.cfm>. Acesso em: mar. 2008.

. Lei № 9648/1998. Altera dispositivos das Leis 3.890-A de 25.04.1961;

8.666 de 21.06.1993, 8.987 de 13.02.1995; 9.074 de 07.07.1995; 9.427 de 26.12.1996, e autoriza o Poder Executivo a promover a reestruturação da Centrais Elétricas Brasileiras S.A - ELETROBRÁS e de suas subsidiárias e dá outras providências. Brasília, mai. 1998. Disponível em:

<http://www.aneel.gov.br/biblioteca/pesquisadigit.cfm>. Acesso em: mar. 2008.

Lei № 10848/2004. Dispõe sobre a comercialização de energia elétrica, altera as Leis 5.655 de $20.05 .1971,8.631$ de $04.03 .1993,9.074$ de 07.07.1995, 9.427 de 26.12.1996, 9.478 de 06.08.1997, 9.648 de 27.05.1998, 9.991 de 24.07.2000, 10.438 de 26.04.2002, e dá outras providências. Brasília, mar. 2004. Disponível em: shttp://www.aneel.gov.br/biblioteca/pesquisadigit.cfm>. Acesso em: abr. 2010.

. Decreto № 5163/2004. Regulamenta a comercialização de energia elétrica, o processo de outorga de concessões e de autorizações de geração de energia elétrica, e dá outras providências. Brasília, jul. 2004. Disponível em: <http://www.aneel.gov.br/biblioteca/pesquisadigit.cfm>. Acesso em: abr. 2010. 
CÂMARA DE COMERCIALIZAÇÃO DE ENERGIA ELÉTRICA (CCEE). Diagrama das instituições do setor elétrico. 2011. Disponível em: shttp://www.ccee.org.br>. Acesso em jan. 2011.

- Histórico de preço de liquidação de diferenças - PLD. 2009. Disponível em: shttp://www.ccee.org.br>. Acesso em jan. 2010.

. O SIN e os modelos Newave e Decomp utilizados no planejamento da operação energética e no cálculo do PLD. Treinamento aos agentes, 2007, São Paulo. Acesso em set. 2011.

COMITÊ DE REVITALIZAÇÃO DO MODELO DO SETOR ELÉTRICO. Relatório de progresso n. 2. 2002.

COOPERS\&LYBRAND. Etapa VII - Projeto de reestruturação do setor elétrico brasileiro: relatório consolidado etapa. v. 2, 1997.

DAVID, P. A. et. al. Contratação e aversão ao risco no despacho competitivo da geração. In: XVII Seminário nacional de produção e transmissão de energia elétrica - SNPTEE, Uberlândia, out. 2003.

ESCRIBANO, Á.; PEÑA, J. I.; VILLAPLANA, P. Modeling electricity prices: international evidence. Madrid, jun. 2002. Disponível em: <http://docubib.uc3m.es/ WORKINGPAPERS/WE/we022708. pdf>. Acesso em: 3 de fev. 2008.

FEDERIGHI, Edson D. \& HIROKI, Marcelo. Exposição ao mercado de curto prazo para clientes livres: uma análise da eficácia da contratação de longo prazo para mitigar os riscos envolvidos. Trabalho de formatura do curso de graduação do Departamento de Engenharia de Energia e Automação Elétricas da Escola Politécnica da Universidade de São Paulo, 2008.

HULL, J. Introdução aos mercados futuros e de opções. Prentice Hall. 2005. 
JANNUZZI, G. d.; SWISHER, J. N. Planejamento integrado de recursos energéticos. Autores Associados. 1997.

LIMA, Wagner S. A inserção e operação otimizada de centrais termelétricas no sistema elétrico interligado brasileiro. Tese (Doutorado). Escola Politécnica da Universidade de São Paulo, 2003.

MATTOS, L. B. Uma estimativa da demanda industrial de energia elétrica: 19742002. Out. 2004. Disponível em: <http://ageconsearch.umn.edu/bitstream/43986/2/ Artigo\%2010\% 20(04.124).pdf>. Acesso em: 15 de jun. 2009.

MINISTÉRIO DE MINAS E ENERGIA (MME). Portaria № 73/2010. Disponibiliza para Consulta Pública, a proposta de Portaria, visando estabelecer diretrizes para regulamentar a cessão de excedentes contratuais de energia elétrica por consumidores livre e especial, definidos pelo Decreto 5.163 de 30.07.2004 e pela Resolução ANEEL 247 de 21.12.2006. Brasília, mar. 2010. Disponível em: <http://www.aneel.gov.br/biblioteca/pesquisadigit.cfm>. Acesso em: jul. 2010.

MAYO, R. Derivativos de Eletricidade \& Gerenciamento de Risco. Rio de Janeiro: Synergia, 2009.

OLIVEIRA, A. M. Estratégia ótima de oferta de preços no mercado de curto prazo em sistemas com predominância hidrelétrica. 2003. Tese (Doutorado) - Pontifícia Universidade Católica do Rio de Janeiro, Rio de Janeiro, 2003.

SILVA, E. L. Formação de preços em mercados de energia elétrica. Porto Alegre: Sagra Luzzato, 2001

SOUZA, Z. F. A importância da reação da demanda na formação dos preços de curto prazo em mercados de energia elétrica. 2009. Dissertação (Mestrado) Escola Politécnica da Universidade de São Paulo, São Paulo, 2010.

VITORINO, Roney N. Análise de estratégias de comercialização de energia para consumidores livres no novo ambiente institucional do setor elétrico brasileiro. São Paulo, Trabalho de formatura do curso de graduação do Departamento de Engenharia de Energia e Automação Elétricas da Escola Politécnica da Universidade de São Paulo, 2005. 
VON DER FEHR, N. H; WOLAK, F. A. Power sector reforms in Brazil: some issues. Jan. 2003. Disponível em: <ftp://zia.stanford.edu/pub/papers/ vonderfehrwolak.pdf>. Acesso em: 15 de mai. 2008.

WOLAK, F. A. An empirical analysis of the impact of hedge contracts on bidding behavior in a competitive electricity market. Mar. 1999a. Disponível em: $<$ http://faculty-gsb.stanford.edu/wilson/archive/E542/classfiles/Wolak Hedges Australia.pdf>. Acesso em 10 de nov. 2008.

Market design and price behavior in restructured electricity markets: an international comparison. 1999b. Disponível em: < $\mathrm{ftp}$ ://zia.stanford. edu/pub/papers/taiwan. pdf>. Acesso em: 24 de out. 2008. 